RAQUEL AGUIAR TAVARES

\title{
Estudo histológico da matriz extracelular do músculo cricofaríngeo em cadáveres de diferentes idades
}

\author{
Tese apresentada à Faculdade de \\ Medicina da Universidade de São Paulo \\ para obtenção do título de Doutor em \\ Ciências \\ Área de concentração: Otorrinolaringologia \\ Orientador: Prof. Dr. Luiz Ubirajara Sennes
}

São Paulo

2009 
RAQUEL AGUIAR TAVARES

\section{Estudo histológico da matriz extracelular do músculo cricofaríngeo em cadáveres de diferentes idades}

Tese apresentada à Faculdade de Medicina da Universidade de São Paulo para obtenção do título de Doutor em Ciências

Área de concentração: Otorrinolaringologia

Orientador: Prof. Dr. Luiz Ubirajara Sennes

São Paulo

2009 
Dados Internacionais de Catalogação na Publicação (CIP)

Preparada pela Biblioteca da

Faculdade de Medicina da Universidade de São Paulo

(C)Reprodução autorizada pelo autor

Tavares, Raquel Aguiar

Estudo histológico da matriz extracelular do músculo cricofaríngeo em cadáveres de diferentes idades / Raquel Aguiar Tavares. -- São Paulo, 2009.

Tese(doutorado)--Faculdade de Medicina da Universidade de São Paulo.

Departamento de Oftalmologia e Otorrinolaringologia.

Área de concentração: Otorrinolaringologia.

Orientador: Luiz Ubirajara Sennes.

Descritores: 1.Esfíncter esofágico superior 2.Colágeno tipo I 3.Colágeno tipo III 4.Tecido elástico 5.Fibronectinas 6.Versicanas 7.Imunoistoquímica

USP/FM/SBD-086/09 
Dedico

Ao Chung, meu melhor presente.

Eu te amo.

Aos meus pais Lígia e Tota.

Por tudo. Sempre. 


\section{AGRADECIMENTOS}

À Deus, que torna meus sonhos possíveis.

À Nossa Senhora de Fátima que me guarda diariamente.

Aos meus irmãos llo e Felipe, agradeço pelo companheirismo de toda a vida, pela torcida e pelo apoio irrestrito.

Ao Professor Dr. Luis Ubirajara Sennes, Professor Livre Docente, Coordenador do Programa de Pós Graduação em Otorrinolaringologia da Faculdade de Medicina da Universidade de São Paulo (FMUSP), meu orientador, dotado de sensatez e discernimento incomuns, que tornou possível a realização dessa tese.

À Professora Dra. Thais Mauad, Professora Associada do Departamento de Patologia da FMUSP, "minha orientadora", pela oportunidade de trabalhar em conjunto, pelas horas gastas em orientar, discutir, questionar e sempre buscar o melhor resultado. Admiro sua dedicação à vida acadêmica.

Ao Professor Dr. Ricardo Ferreira Bento, Professor Titular da Disciplina de Otorrinolaringologia. As portas da sua sala estão sempre abertas aos que o procuram. Agradeço seu incentivo, sua disponibilidade e seu dinamismo inspirador.

Ao Dr. Rui Imamura, grande médico e mestre, pela contribuição na análise estatística desta tese e sua grande disposição em sempre ensinar, desde os tempos da residência. 
Ao Professor Dr. Domingos Hiroshi Tsuji, Professor Livre Docente da FMUSP. Agradeço sua amizade e grande ajuda nos momentos difíceis da vida

Ao Dr. Luis Fernando Silva, pela sua colaboração na execução deste projeto e pela disponibilidade de sempre ajudar a todos.

Ao Dr. Ricardo Luis Carrau, responsável pelo Swallowing Disorders Center da Universidade de Pittsburgh, Pensilvânia. Agradeço sua amizade, sua acolhida quando o visitei, sua disponibilidade e seus importantes comentários durante a elaboração do artigo desta tese.

À Dra. Patrícia Paula Santoro, médica assistente e responsável pelo Ambulatório de Disfagia do Hospital das Clínicas da FMUSP. Agradeço pelos anos de convivência, pelo seu bom humor e pelo aprendizado em disfagia.

Às Dra. Elza Maria Lemos, Fga. Cristina Lemos Fúria, Dra. Roberta Garcia, Fga. Débora Cardoso, pela troca de conhecimentos, incentivo e curiosidade em entender melhor o mundo da disfagia.

Aos colegas de pós-graduação Dr. Flávio Akira Sakae, Dr. Rogério Buhler e, especialmente, à Dra. Daniele Andrade pela troca de informações e incentivo mútuo durante essa jornada.

Às biólogas Ângela Santos e Maria Cristina Medeiros, pela contribuição na realização da imunohistoquímica, além da grande disposição em ajudar.

Ao Dr. Michel Cahali por seus valiosos comentários durante o exame de qualificação. 
À Dra. Signe Schuster Grasel, pelo incentivo e amizade.

Ao Nilton Fontes Neuman, Chefe de Seção de Arquivos Necorcópicos do Serviço de Verificação de Óbitos da Capital, pela ajuda na coleta de material para esse estudo.

À Maria Marileide Alves, meu anjo da guarda. Obrigada pela sua ajuda, sempre, independente de onde esteja e do que esteja fazendo.

Aos meus verdadeiros amigos, cujos nomes não precisam ser citados, pois eles mesmos sabem da sua real importância na minha vida e na realização dessa tese. Obrigada por tudo.

Ao cadáver desconhecido. 
Normas para publicação no periódico The Laryngoscope .......... ix

Artigo submetido ........................................................... XV

Lista de figuras e quadros ...................................................... $\quad$ xxxiii

Lista de tabelas ....................................................................

Lista de abreviaturas e siglas ................................................. $\quad$ xxxviii

Lista de símbolos …......................................................... $\mathrm{xxxviii}$

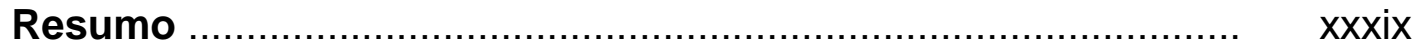

Summary …..................................................................

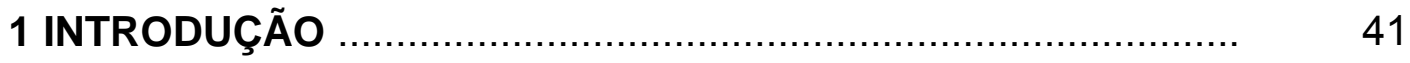

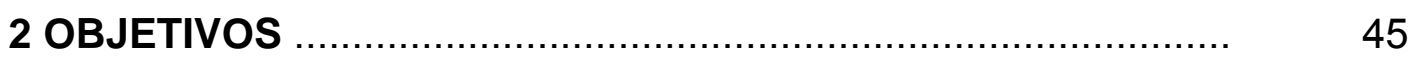

3 REVISÃO DA LITERATURA .............................................. 47

3.1 A transição faringoesofágica e o músculo cricofaríngeo ........... 48

3.1.1 Anatomia do músculo cricofaríngeo ........................... 48

3.1.2 Fisiologia do músculo cricofaríngeo ..................................... 50

3.1.3 Histologia do músculo cricofaríngeo ............................. 51

3.2 Ação do envelhecimento e do sexo ........................................ 54

3.2.1 Sobre a deglutição .......................................................... 54

3.2.2 Sobre o tecido muscular esquelético e sua matriz extracelular ................................................................ 56

3.3 O tecido conjuntivo .......................................................

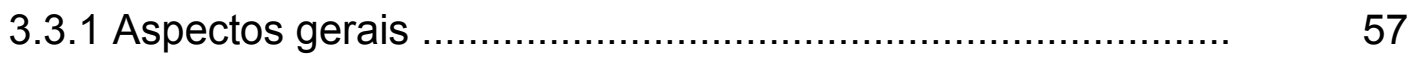

3.3.2 O sistema de fibras colágenas ............................................ 58

3.3.2.1 Métodos histológicos para o estudo do colágeno ................ 61

3.3.2.2 Ação do envelhecimento sobre o sistema de fibras colágenas ................................................................. 62

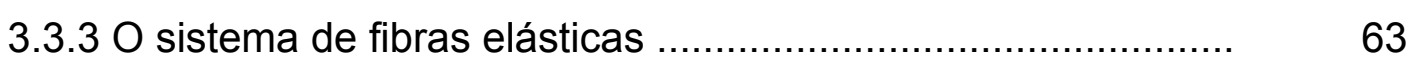

3.3.3.1 Métodos histológicos para o estudo das fibras elásticas ..... $\quad 66$

3.3.3.2 Ação do envelhecimento sobre o sistema de fibras elásticas 


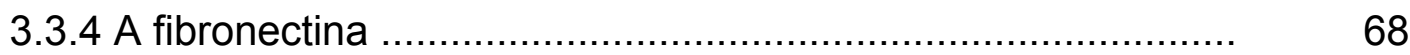

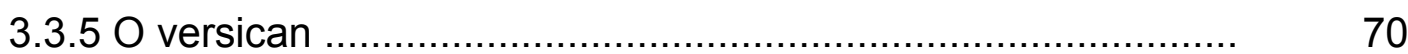

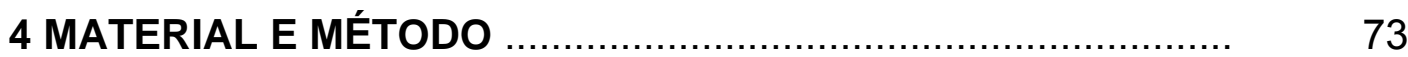

4.1 Aspecto ético ..................................................................

4.2 Casuística ......................................................................

4.2.1 Seleção da amostra .........................................................

4.2.2 Dissecção do músculo cricofaríngeo ..........................

4.2.3 Preparações histológicas ............................................... $\quad 76$

4.3 Análise morfométrica ......................................................

4.4 Análise estatística ...............................................................

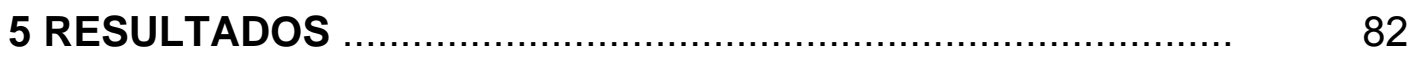

5.1 Característica da amostra ....................................................... 83

5.2 Distribuição das fibras do sistema colagênico e elástico por métodos histoquímicos ......................................................... 84

5.3 Distribuição dos elementos da matriz extracelular por métodos imunoistoquímicos ......................................................... 88

5.4 Associação entre as medidas e a idade ................................... 91

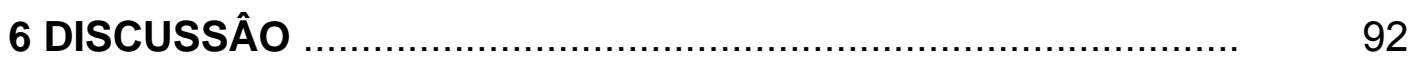

6.1 Da seleção da amostra ...........................................................

6.2 Da quantificação dos elementos da matriz extracelular ............. 96

6.3 Das alterações correlacionadas à idade e ao sexo ................... 101

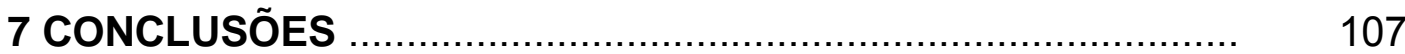

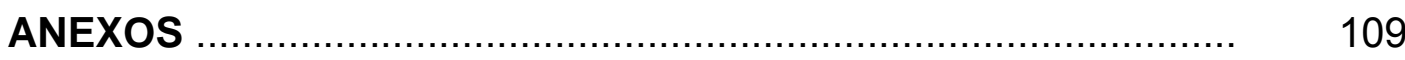

ANEXO A - Dados dos cadáveres obtidos no SVOC ………......... 110

ANEXO B - Método Picrossírius ..................................................... 112

ANEXO C - Método de Resorcina-fucsina de Weigert com oxidação prévia por oxona ......................................... 113

ANEXO D - Método Imunoistoquimico ………………………...... 114

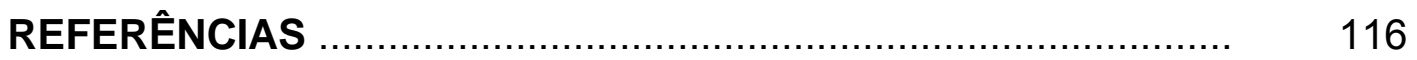

APÊNDICE 


\title{
NORMAS PARA PUBLICAÇÃO
}

\author{
"THE LARYNGOSCOPE"
}

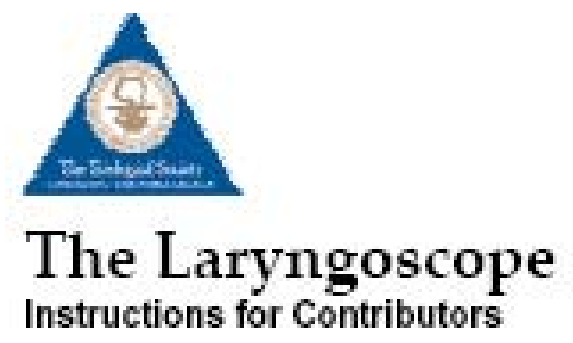

Mission Statement and Scope

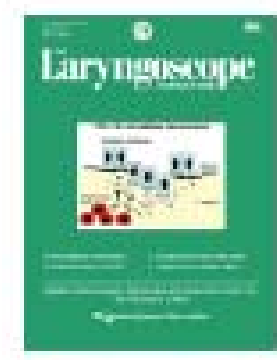

The Laryngoscope is an international peer-reviewed periodical dedicated to the advancement of patient care in otolaryngology-head and neck surgery. As such, The Laryngoscope publishes original articles relating to the clinical and basic science aspects of otolaryngology-head and neck surgery. The Laryngoscope reserves the right to exclusive publication of all accepted manuscripts, and will not consider any manuscript previously published or under review by another publication. Once accepted for review, the manuscript must not be submitted elsewhere. Unethical publishing such as plagiarism, undisclosed conflicts of interest, inappropriate authorship, and duplicate publication are forbidden. This includes publication in a non-otolaryngologic journal or in another language. In case of doubt, disclosure is essential and the editor is available for consultation. Transfer of copyright to The Laryngoscope is a prerequisite of publication.

All authors must sign the copyright transfer form. (This does not preclude publication of abstracts in the transactions or proceedings of the various societies.)

Authors must disclose any financial relationship at the time of submission and must be updated by the authors prior to the time of publication. Information that could be perceived as potential conflict of interest must be stated, including personal relationships, interests, and affiliations over the past three years. This information includes, but is not limited to, grants or funding, employment, affiliations, patents, inventions, honoraria, consultancies, royalties, stock options/ownership, or expert testimony.

Manuscripts are subject to peer review and revision may be required as a condition of acceptance. These instructions apply to all submissions.

Manuscripts reporting original scientific investigation, both basic science and clinical reports, are encouraged to use the manuscript format described below. In addition to fulllength original manuscripts, The Laryngoscope will consider for publication Contemporary Reviews, Scientific Reviews, Rapid Communications, Case Reports, Letters to the Editor, and "How I Do It" submissions.

Contemporary Review manuscripts should review topics of contemporary interest and importance, and ideally should address controversial issues by expressing both sides of the controversy. The review should emphasize the best evidence currently available. We especially invite collaborative efforts by authors representing different points of view.

Scientific Review manuscripts should address contemporary topics in otolaryngology- head and neck surgery that are controversial or in a state of rapid flux. The review should be comprehensive and authoritative as reflected by a contemporary bibliography. The manuscript format should conform to the format described below (see Manuscript Preparation) for original scientific manuscripts.

Rapid Communications report information of importance to otolaryngology-head and neck surgery not suitable for presentation as a full-length manuscript. Rapid Communications should be limited to three double-spaced typewritten pages. An abstract and references are not required.

Case Reports describes encounters with one or several patients with unique or unusual clinical situations. The key to an acceptable Case Report is the identification of a clinical pearl or clinical wisdom that could benefit future patients. Case Reports should be 
limited to four double-spaced typewritten pages and no more than eight references. An abbreviated abstract limited to less than 100 words that captures the essential value of the Case Report should be included.

Letters to the Editor should be directed to the Editor regarding manuscripts previously published in which significant scientific controversy exists. Letters to the Editor deemed appropriate for publication will be submitted to the author(s) of the manuscript of interest comment. Letters to the Editor should be limited to three double-spaced type written pages including references.

"How I Do It" submissions report innovative solutions to clinical problems. Originality and quality of illustrations (when appropriate) are essential ingredients. "How I Do It" manuscripts should have a clear practical value and be no more than four doublespaced typewritten pages. No abstract is required.

\section{Authorship Criteria and Responsibility}

The Laryngoscope insists that all authors are truly qualified to be listed as such. Others who have contributed to the work but are not qualified to be authors should be "acknowledged" at the end of the article.

Authorship credit is based only on having made a substantial contribution to the published work by virtue of meeting all the following three criteria:

1. Conception and design of project or analysis of the manuscript data;

2. Drafting or critically revising the content of the manuscript submitted for publication, and;

3. Giving final approval of the version to be published.

All three criteria must be met for an individual to be listed as an author or co-author on a published paper.

Please note that other criteria, which do not qualify an individual for "author status" include the following:

1. Supplying funding or other resources;

2. Collecting data (only);

3. General supervision of the research group, and;

4. Being departmental chair or division chief.

\section{Special Approval}

Manuscripts that include information obtained from human or animal research must include (in the text or an appropriate footnote) verification of the review and approval of the appropriate institutional research oversight committee for the work that is reported.

\section{Preparation of Manuscript}

Original scientific manuscripts and review articles that do not adhere to the following instructions will be returned to the corresponding author for technical revision before undergoing peer review. PLEASE NOTE: if you are not listed in the system as the "Corresponding Author," the submission will not show up in your queue for approval.

\section{Manuscript Submission}

Until August 27th, 2008 Authors are to submit their manuscripts through the Webbased tracking system at https://lscope.edmgr.com

Starting August 27th, 2008 Authors must submit their manuscripts online through http://mc.manuscriptcentral.com/lscope

Manuscripts submitted online are received on the day of submission and quickly assigned to reviewers. Through individual Author Centers on this website, authors can view the status of their manuscripts as they progress through the review process.

Notification of the disposition of each manuscript will be sent by E-mail to the corresponding author on the day of decision. To submit your manuscript online:

o Go to http://mc.manuscriptcentral.com/lscope

- Click on the "Check for Existing Account" button at the bottom of the opening page. If you do not already have an account, then create one by clicking on the "Create an Account" button. You then will be able to submit your manuscript.

o Click on "Author Center." Follow the on-screen instructions carefully. Submit the complete manuscript with text (including references), tables, and figures as separate files. You do not need to mail paper copies of your manuscript.

- At the end of a successful submission, you will see a confirmation screen with your manuscript number, and you will receive a separate E-mail confirmation of manuscript reception by the journal. If these two messages do not appear, then go 
into your Author Center and make sure that you have clicked on the "Submit" button or contact technical support at support@scholarone.com .

Manuscript format: The manuscript for the body of the text should not exceed $\mathbf{1 5}$ doublespaced typewritten pages. (Please see above additional requirements for Rapid Communication, "How I Do It," etc.) The elements of a full-length article should be in the following sequence: Title Page, Structured Abstract and Key Words, Text (Introduction, Materials and Methods, Results, Discussion, Conclusion), Acknowledgment, References, Tables, and Figure Legends. Each of these elements should begin on a new page, and each page should have a short running title (see next section: Title Page).

Title pages:

A. Title page must be submitted as a separate file on the first page of the online system. This should contain: article title (not to exceed 75 characters, including spaces).

B. Title page must be submitted as part of your manuscript. This should contain: article title (not to exceed 75 characters, including spaces); names of authors, their degrees and affiliations (dept., institution, city, state, country); institution where the work was done (indicate which author is in which department); a short running title of no more than 45 letters and spaces; source of financial support or funding; and a footnote indicating the author to whom correspondence, reprint requests, and proofs will be sent, with complete address (including e-mail address and postal codes) and telephone and telefax numbers. If the paper was presented at a meeting, give society name, city, state, country, and exact date meeting was held.

The title page must also include disclosure of funding received for this work from any of the following organizations: National Institutes of Health (NIH); Wellcome Trust; Howard Hughes Medical Institute (HHMI); and other(s).

Structured abstract and key words: Limit the abstract to 250 words. Do not cite references in the abstract. Limit the use of abbreviations and acronyms. Use the following subheads: Objectives/Hypothesis, Study Design (randomized, prospective, etc.), Methods, Results, and Conclusions.

Text: The text is to be divided into five sections with the following headings: Introduction, Materials and Methods, Results, Discussion, and Conclusion. Define abbreviations at first mention in text and in each table and figure. If a brand name is cited, supply the manufacturer's name and address (city and state/country). The introduction should be limited to two paragraphs of pertinent information. The discussion should not be an exhaustive review of the literature; it should be succinct and limited to conclusions that can be reached based on the results.

Abbreviations: Use generic names for drugs. List supplier of manufacturer for products and instruments; include supplier's city and state (e.g., Glaxo Wellcome, Research Triangle Park, NC). Audiograms must be plotted according to ISO standards and must be in black and white. For commonly accepted abbreviations, consult Logan's Medical and Scientific Abbreviations. Authors are encouraged to consult Dorland' Illustrated Medical Dictionary (28th Edition), American Medical Association Manual of Style, and Council of Biology Editors Style Manual (available from the Council of Biology Editors, 9650 Rockville Pike, Bethesda, MD 20814, USA). The full term for which an abbreviation stands should precede its first use unless it is a standard unit of measurement.

Style: Pattern manuscript style after the American Medical Association Manual of Style (9th Edition), Stedman's Medical Dictionary (27th Edition) and Merriam Webster's Collegiate Dictionary (10th Edition) should be used as standard references. Refer to drugs and therapeutic agents by their accepted generic or chemical names, and do not abbreviate them. Use code numbers only when a generic name is not yet available. In that case, supply the chemical name and a figure giving the chemical structure of the drug. Capitalize the trade names of drugs and place them in parentheses after the generic names. To comply with trademark law, include the name and location (city and state in USA; city and country outside USA) of the manufacturer of any drug, supply, or equipment mentioned in the manuscript. Use the metric system to express the units of measure and degrees Celsius to express temperatures, and SI units rather than conventional units.

Permissions: The author is responsible for obtaining written permission to reproduce previously published material (direct quotations, unpublished data, tables, or figures) from the copyright holder. Enclose all letters granting permission at the time the manuscript is 
submitted for publication. Any permissions fees that might be required by the copyright owner are the responsibility of the authors requesting use for the borrowed material, not the responsibility of the Triological Society or Wiley-Blackwell. Photographs of recognizable persons must be accompanied by a signed release from the patient. For a photograph of a minor, signed parental permission is required.

Internal Review: All authors are strongly encouraged to have their manuscripts thoroughly and critically reviewed within their institution before submitting to The Laryngoscope.

References: The authors are responsible for the accuracy of the references. The Journal complies with the reference style given in "Uniform Requirements for Manuscripts Submitted to Biomedical Journals" (available from The New England Journal of Medicine, Bulk Reprints, 1440 Main Street, Waltham, MA 02154, USA; send self-addressed stamped envelope). References are to be cited in numerical order in text and identified by Arabic numerals set in superscript type. Authors will be charged $\$ 3.00$ for each reference over 15 . The reference section should be typed double-spaced at the end of the text, following the sample formats given below. For abbreviations of journal names, refer to List of Journals Indexed in Index Medicus (available from the Superintendent of Documents, U.S. Government Printing Office, Washington, DC 20402, USA; DHEW Publication No. (NIH) 91 267; ISSN 0093-3821).

Provide all authors' names when fewer than seven; when seven or more, list the first three and add et al. Provide article titles and inclusive pages. "Unpublished observations" and "personal communications" do not qualify as references and should be placed parenthetically in the text. Accuracy of reference data is the responsibility of the author. Sample references are given below:

Journal article

1. Rand NS, Dawson JM, Juliao SF, et al. In vivo macrophase recruitment by murine intervertebral disc cells. J Spinal Disord 2001; 14:339-342.

Book chapter

2. Todd VR. Visual information analysis: frame of reference for visual perception. In: Kramer P, Hinojosa J, eds. Frames of Reference for Pediatric Occupational Therapy. Philadelphia, PA: Lippincott Williams \& Wilkins; 1999:205-256.

Entire book

3. Webster NR, Galley HF. Anaesthesia Science. Oxford, UK: Blackwell Publishing, Ltd.; 2006.

Software

4. Epi Info [computer program]. Version 6. Atlanta, GA: Centers for Disease Control and Prevention; 1994.

Online journals

5. Friedman SA. Preeclampsia: a review of the role of prostaglandins. Obstet Gynecol [serial online]. January 1988;71:22-37. Available from: BRS Information Technologies, McLean, VA. Accessed December 15, 1990.

Database

6. CANCERNET-PDQ [database online]. Bethesda, MD: National Cancer Institute; 1996. Updated March 29, 1996.

Websites

7. Gostin LO. Drug use and HIVIAIDS [JAMA HIVIAIDS Web site]. June 1, 1996. Available at: http://www.ama-assn.org/special/hiv/ethics. Accessed June 26, 1997.

Figures

Each figure must be identified individually and within the text of the manuscript. Black and white illustrations will be published without charge. Authors will be charged for color illustrations in print. Color illustrations online are free of charge. The Publisher will provide, upon request, an estimate of the cost of color artwork.

Digital art needs to be created/scanned and saved and submitted as either a TIFF (tagged image file format), an EPS (encapsulated postscript) file. PPT (Power Point) files will also be accepted. Electronic photographs-radiographs, CT scans, and so on-and scanned images must have a resolution of at least $300 \mathrm{dpi}$ (dots per inch). Line art must have a resolution of at least $1200 \mathrm{dpi}$. If fonts are used in the artwork, they must be converted to paths or outlines or they must be embedded in the files. Color images must be created/scanned and saved and submitted as CMYK files. If you do not have the capability 
to create CMYK files, please disregard this step. Indicate in your cover letter that you are unable to produce CMYK files. Cite figures consecutively in the text, and number them in the order in which they are discussed.

Digital Art Checklist:

o Create and submit artwork in the actual size it will appear in the journal

- Crop out any extra white or black space surrounding the image

- Text within figures should be in an acceptable font (Helvetica is preferred) and sized consistently throughout the artwork using 8-12 point type

o Text within figures should be embedded in the file or converted to an outline or path

o For black and white images: create and save in grayscale format

o For color files: create and save in CMYK format (not RGB)

o For line art: save and submit at a resolution of at least $1200 \mathrm{dpi}$

o For images/photographs: save and submit at a resolution of at least $300 \mathrm{dpi}$

- For combination halftones: save and submit TIFF or EPS files. Do not select "Save as Compressed TIFF" when saving files. PowerPoint files are also acceptable

o Save each figure as a separate file and save them separate from the accompanying text file(s). For multipanel or composite figures only: send as one files with each part labeled the way it is to appear in print

o Name figures in the format: corresponding author's last name_figure 1.tif, etc.

o Upload figures consecutively to the submission site.

Detailed Figure Instructions: Please refer to this website for detailed information on digital figure preparation, and to check your figure instantly for printer compatibility: http://rapidinspector.cadmus.com/Rapidlnspector/docs/index.html

Figure legends: Each figure must be accompanied by an explanatory legend, typewritten with double spacing (legends should be separate from the figures, but do not use a separate sheet for each legend). They should be brief and specific, and they should appear on a separate manuscript page after the references. Use scale markers in the image for electron micrographs, and indicate the type of stain used. Explain all symbols used in the figure.

Tables: Each table must be identified individually and within the text of the manuscript. Do not include the same information in both tables and figures. Create tables using the table creating and editing feature of your word processing software (e.g., Word, WordPerfect). Do not use Excel or comparable spreadsheet programs. Group all tables in a separate file. Tables should be typed neatly, each table on a separate sheet, with the title above and any notes below. Explain all abbreviations. Tables should be numbered consecutively beginning with Roman numeral I. A table must have at least two columns. Lists are to be incorporated into the text. Each table should appear on a separate page and should include the table title, appropriate column heads, and explanatory legends (including definitions of any abbreviations used). Do not embed tables within the body of the manuscript. They should be self-explanatory and should

supplement, rather than duplicate, the material in the text. Do not use patient initials in tables. Patients should be referred to by sequential Arabic numerals, not by their initials.

\section{Supporting Information (Supplementary Materials):}

Authors may publish additional article-related materials online that complements and reinforces information published in the print journal. Supplementary material posted online is intended to enhance print article content, and may include figures, tables, movies and animation.

All supplemental materials must be submitted with the original submission via Manuscript Central for peer-review and be approved by the Editor in order to be published online. Authors should reference the fact that they have supplied supplemental data with their submission in their cover letter as well as designate the files as Supplemental Files during upload.

There are no restrictions on file types of the data that you submit. Please keep in mind, however, that the more universal the file type, the more accessible to the community.

Because all supplementary materials submitted for addition online are posted exactly as provided to the Publisher, authors are advised to review materials carefully. Data will be posted as it is submitted; it will not be professionally edited or proofread. No additional work or file processing will be performed on any submission. The Publisher will not be responsible for errors or omissions. 
Audio and Video Files: Short audio and video clips may be submitted for posting online as a .wav, .avi, .mov or .mpg file format. Audio and video files must be compressed to the smallest possible size that still allows for high resolution and quality presentation.

The total size of all clips, along with other submitted files for any given article, should not exceed 5MB. File size limitation is intended to ensure that end-users are able to download and view files in a reasonable time frame. If files exceed the specified size limitation, they will not be posted to online and returned to the author for re-submission.

Submitting Revisions: If you have been invited to submit a revised manuscript, please submit it online via your author center following instructions found there. When submitting a revision, please submit both a clean copy and marked copy of the manuscript. The marked copy should highlight all of the changes made the by authors after the original review. Authors can use the track changes feature of the Microsoft Word program to create a marked copy. Authors also should submit all tables and figures in separate files for production purposes.

\section{After Acceptance}

Page proofs and corrections: Corresponding authors will receive will receive electronic page proofs to check the copyedited and typeset article before publication. Portable document format (PDF) files of the typeset pages and support documents (e.g., reprint order form) will be sent to the corresponding author by e-mail. Complete instructions will be provided with the e-mail for downloading and printing the files and for returning the corrected pages to the Publisher. It is the author's responsibility to ensure that there are no errors in the proofs. Changes that have been made to conform to journal style will stand if they do not alter the authors' meaning. Only the most critical changes to the accuracy of the content will be made. Changes that are stylistic or are a reworking of previously accepted material will be disallowed. The Publisher reserves the right to deny any changes that do not affect the accuracy of the content. Authors may be charged for alterations to the proofs beyond those required to correct errors or to answer queries.

Proofs must be checked carefully and corrections returned within 48 hours of receipt, as requested in the communication accompanying the page proofs.

Reprints Authors will receive a reprint order form and a price list with the page proofs. Reprint requests should be faxed to the publisher with the corrected proofs. Reprints are normally shipped 4 to 6 weeks after publication of the issue in which the item appears. Contact the Reprint Department: Email: reprints@wiley.com with any questions.

Publisher's Contact: Email corrected page proofs and any other related materials to Production Editor, The Laryngoscope, kaccaval@wiley.com

Manuscript Checklist (before submission)

o Title page with complete mailing address and telephone, telefax and e-mail of corresponding author

- Abstract in structured format and keywords

o References double-spaced in AMA style and in proper format, and numerical order in the body of the text

o Permission to reproduce copyrighted materials or signed patient consent forms

- Acknowledgments listed for grants and technical support

o Manuscript conforming to criteria listed in Instructions to Authors

o Clear indication of approval of appropriate institutional research oversight committee

Note to NIH Grantees: Pursuant to NIH mandate, Wiley-Blackwell will post the accepted version of contributions authored by NIH grant-holders to PubMed Central upon acceptance. This accepted version will be made publicly available 12 months after publication. For further information, see www.wiley.com/go/nihmandate . 


\section{Extracellular matrix composition of the cricopharyngeus muscle}

Raquel Aguiar Tavares, $M^{1{ }^{1 *}}$, Luiz Ubirajara Sennes, $M D^{1}, \mathrm{PhD}$, Thais Mauad, MD, $\mathrm{PhD}^{2}$, Rui Imamura, MD, $\mathrm{PhD} 1$, Luiz Fernando Silva, $\mathrm{MD}^{2}$, Ricardo Luis Carrau, MD³.

1 Otolaryngology Department, University of São Paulo, School of Medicine, São Paulo, Brazil.

2 Pathology Department, University of São Paulo, School of Medicine, São Paulo, Brazil.

3 Otolaryngology Department, University of Pittsburgh, School of Medicine, Pittsburgh, Pennsylvania, USA.

This paper was presented at XIX World Congress of Oto-rhino-laryngology, International Federation of Oto-rhino-laryngological Societies (IFOS), São Paulo, São Paulo, Brazil, June 1-5, 2009.

This work was supported by FAPESP (São Paulo State Research Agency) and HCFMUSP.

* Correspondence to Raquel Aguiar Tavares, Rua Silva Paulet 776, Ap.402, 60120-020, Fortaleza, Ceará, Brasil. E-mail: raq_tavares@terra.com.br 


\section{ABSTRACT}

Objectives: To analyze the presence and distribution of total collagen, type I and III collagen, elastic fibers, fibronectin and versican in the endomysium of the cricopharyngeus muscle in adults of different ages. Study Design: Cross sectional analysis of human cricopharyngeus muscle. Methods: Twentyseven muscles obtained from autopsies of men and women with ages that range from 28 to 92 years were analyzed with the Picrosirius method, oxidized Weigert resorcin-fuchisin, immunnohistochemistry and image analysis. Results: Collagen had the highest density among the analyzed components. Type I collagen was more prevalent than type III collagen. Elastic fibers surrounded each muscle cell, aligned longitudinal by to their long axis, and associated with traversing fibers; thus, forming a fiber network embedding muscle cells. There was a wide variation on fibronectin and versican content among the specimens. We found no statistically significant differences between the proportion of the components of extracellular matrix and factors such as gender, age and smoking habit. Conclusion: Our findings suggest that the presence and distribution of these extracellular matrix components are important for the homeostasis of the cricopharyngeus muscle. The higher proportion of type I and III collagen and the arrangement of the elastic fibers can contribute to the cricopharyngeus elastic behavior muscle. Variations in the expression of fibronectin and versican can be resultant of its injury susceptibility. No clear histological differences in the ECM could be observed with age, sex and smoking habits.

Key Words: Collagen fibers, elastic fibers, fibronectin, versican, cricopharyngeus muscle, immunnohistochemical 


\section{INTRODUCTION}

The cricopharyngeus muscle (CPM) is thought to play an important function in swallowing and related activities 1. Its elastic behavior is likely to depend not only on its contractile components (striated muscle), but also on its intramuscular connective tissue ${ }^{2}$. Few studies have assessed CPM normal histological structure in man and there is very few information about its extracellular matrix (ECM) composition ${ }^{1,3,4}$.

Collagens are a source of tensile strength in the muscular tissue and elastic fibers are essential to tissue resiliency ${ }^{5}$. Versican, a proteoglycan condroitin sulphate, modulates the cell growth and maturation, and also keeps the hydration of the $\mathrm{ECM}^{6}$. Fibronectin, a large glycoprotein, participates on cells adhesion, cytoskeletal organization, cellular migration, differentiation and homeostasis ${ }^{7}$. In this study our aim was to analyze quantitatively the major ECM proteins, total collagen, type I collagen, type III collagen, elastic fibers, versican and fibronectin in the endomysium of CPM in adult subjects. As a secondary goal, we aimed to ascertain whether or not gender and age affected the composition of the endomysium ECM.

\section{METHODS}

Our study was approved by the Ethics Committee for Research Project Analysis of the Clinical Board of the University of São Paulo School of Medicine.

Human cricopharyngeus muscles were obtained from autopsies of adults at São Paulo Autopsy Service, University of São Paulo. We obtained twenty-seven specimens from twenty men and seven women with ages that ranged from 28 to 92 years, median age of 54 years. Sixteen cadavers were of the Caucasian, and eleven were of African descent. Eleven were smokers or ex-smokers. Three subjects had an uncertain smoking history. We only harvested muscles from cadavers that were autopsied within 24 hours after death that were victims of sudden death or who died of known diseases that could not have affected the CPM. We excluded cases subject who have undergone endotracheal or nasogastric intubation. We obtained the 
specimens after an en bloc exeresis of larynx, pharynx and the upper esophageal sphincter (UES). Once the CPM was identified we sampled its middle third, including muscle and mucosa. The specimens were fixed in $10 \%$ buffered formalin solution for 24 hours, after which the specimens were dehydrated in progressive alcoholic concentrations and embedded in paraffin. Tissue blocks were submitted to $4-\mu m$-thick histologic sections and stained with hematoxylin and eosin (H\&E) for the initial analysis.

Histological slides were also stained with Sirius red to visualize collagen fibers, and with oxidized Weigert resorcin-fuchisin to elastic fibers as described previously ${ }^{5}$. This latter technique selectively stains the elastic fibers (elastin and preelastin fibers) ${ }^{3}$ For the analysis of type I collagen, type III collagen, fibronectin and versican expression, immunnohistochemical reactions were carried out using, respectively, collagen type I antibody (Calbiochem, San Diego, CA) (1:1000 dilution), collagen type III MAB II antibody (US Biological, Swampscott, MA) (1:150 dilution), fibronectina antibody (Dako, Carpinteria, CA) (1:4000) and antihuman antibody large proteoglycan versican (Seikagaku America, Inc., ljamsville, MD) (1:250 dilution). Sections were incubated overnight with the primary antibody in $1 \%$ BSA/PBS between $4^{\circ} \mathrm{C}$ and $8^{\circ} \mathrm{C}$. As a secondary antibody, Vectastain (Vector Laboratories, Burlingame, CA) was used for type I collagen, Envision + Dual link System (Dako, Carpinteria, CA) was used to type III collagen, fibronectin and versican and 3,3 Diaminobenzidine (Sigma, Steinhein, Germany) was employed as a chromogen. Incubation with PBS supplemented with $1 \%$ BSA instead of the primary antibody served as a negative control.

Measurement of positively stained areas in the CPM endomysium were performed by image analysis using a system comprising a light microscope Leica DMR (Leica Microsystems Wetzlar Gmb H, Wetzlar, Germany) connected to a computer through a video camera and using the software Image pro Plus, version 4.1 (Media Cybernetics, Silver Spring, MD). For each staining slide, fifteen non overlapping areas of the CPM endomysial region at 400x magnification were analyzed per sample. Results were 
expressed as stained area/total area $\left(\mu \mathrm{m}^{2} / \mu \mathrm{m}^{2}\right)$. The measurements were performed by an observer that was blinded to the patient's data. The area of positive staining for each antibody within the marked region of CPM was determined by color threshold. For this purpose, different sections stained with each antibody (six to eight cases per group), as well as negative controls, were used to achieve the best range of positivity in the cases, which was always checked by two experienced pathologists (T. Mauad and L. Silva). These procedures generated a file containing all color selection data, which were afterwards applied to all cases stained with the same antibody. The density of specific ECM compounds was expressed as a percentage of the total CPM area ${ }^{9}$.

\section{Data analysis}

Data are expressed as median and interquartile ranges (IQR). The correlation between age and the different ECM proteins was tested using Spearman test. A T test for unpaired means was used to compare the fractional areas of ECM in subjects grouped by sex. All tests were performed in the SPSS software 13.0 version (SPSS Inc ${ }^{\odot}$, Chicago, Illinois, USA) and $p$ values lower than 0.05 were considered significant.

\section{RESULTS}

Table I shows the age distribution for study group. Table II and III show ECM density of CPM components.

Figure $1 \mathrm{~A}$ shows $\mathrm{H} \& \mathrm{E}$ staining shows $\mathrm{CPM}$ and cricopharyngeal mucosa.

Collagens, elastic fibers, versican and fibronectin were all present within the endomysial ECM of the CPM. Collagen (Figure 1B) and elastic fibers were diffusely present in the CPM endomysium. Thin elastic fibers were present in the endomysium surrounding each muscle cell. They were aligned longitudinally to the long axis of the muscle cell. Transversally oriented thin fibers seemed to traverse the muscle cell, connecting cells among themselves through a fiber network (Figure 1C). In both cell poles, elastic fibers were thicker and more abundant (Figure 1D) 
Types I and III collagens in the endomysium stained diffusely in a fibrillar pattern (Figures $1 \mathrm{E}$ and $1 \mathrm{~F}$ ). Antibodies to fibronectin stained the endomysium, but in a less dense, fibrillar pattern (Figure 1G). Small blood vessels present within the muscle also showed fibronectin staining. In some cases, we could see some fibronectin in the sarcoplasma, especially in the older subjects (Figure 1H). No versican staining was observed in muscle fibers. The density of versican in the endomysium varied among the samples, some showed abundant versican staining whereas in others the staining was almost absent (Figure $1 \mathrm{I}$ and $1 \mathrm{~J}$ ).

No clear histological differences in the ECM could be observed among the different ages and there was no correlation between ECM components and age (Table IV). Similarly, we found no statistically significant difference between the ECM components when correlating the proportions to gender and smoking habits (data not shown).

\section{DISCUSSION}

In this study we analyzed the density of total collagen fibers, type I collagen fibers, type III collagen fibers, elastic fibers, fibronectin and versican in the endomysium of the horizontal portion of CPM in young and old adult subjects. To our knowledge, we are the first to analyze specific components of ECM in CPM in adult subjects with a wide range of age.

It is believed that opening of upper esophageal sphincter (UES) during swallowing is determined by combined effect of relaxation and distensibility of CPM and the antero-superior movement of the cricoid cartilage caused by contraction of the suprahyoid muscles. The relative contribution of these individual factors on UES opening has not been quantified ${ }^{10}$.

The elastic behavior of skeletal muscle depends not only on its contractile components, but also on the intramuscular connective within the muscle tissue $^{2}$. Previous studies on CPM, using histochemical methods, have described large amounts of endomysial connective tissue; therefore, histological studies on CPM endomysium can be useful to better understand its structure and function ${ }^{3,4}$. 
Collagens are the most abundant extracellular fibrous proteins and forms $1-9 \%$ of the free dry mass of skeletal muscle ${ }^{11}$. Indeed, in our study collagens had the highest density among the analyzed ECM components. Collagens type I and III are the major interstitial collagens within the skeletal muscles. Type I collagen plays a key role as supporting structure, as it has a high tensile strength, and is especially suitable for transmitting force. Type III collagen is more prevalent on elastic connective tissues. In tissues where types I and III coexists, like skeletal muscle, their relative proportions affect the architecture of the tissue ${ }^{11}$. Endomysium of different skeletal muscles characteristically shows a higher proportion of type III collagen ${ }^{12}$. Disaccording, we found no statistically significance difference between both collagen types. Although we have used a rigorous study method, these differences can be to different sensibility and specificity of the antibodies used in immunnohistochemical reactions or even represent a biological characteristic of CPM.

Elastic fibers are important components on connective tissues that contain elastomeric proprieties ${ }^{13}$. Oxidized Weigert resorcin-fuchisin identifies the three types of elastic fibers: mature and elaunin elastic fibers, responsible for tissue elasticity and oxytalan fibers, responsible for tissue resistance. The only previous published research addressing elastic fibers in CPM was limited to just affirm that elastic fibers are an abundant in the $\mathrm{CPM}^{1}$, but it provided no description or quantification. Elastic fibers presented an interesting arrangement where thin slightly tortuous elastic fibers surrounded each muscle cell, longitudinal to their long axis, associated with traversing fibers, forming a fiber network that embedded the muscle cells. Such configuration could be responsible, at least in part, for the CPM capacity to rapidly reassume its tonic position after opening during swallows.

Our study is the first to describe fibronectin and versican content in the CPM endomysium. Fibronectin, a large glycoprotein, participates on cells adhesion, cytoskeletal organization, cellular migration, differentiation, and homeostasis $^{7}$. Our results show immuno-positivity for fibronectin on CPM endomysium, a region where firm bindings between collagen and muscle 
fibers are needed. There was a wide variation in the fibronectin content among the samples, and in a few, fibronectin was expressed in the sarcoplasma. Similar findings were seen by Gulati et al. ${ }^{14}$ in regenerating skeletal muscles. Similarly, variations were present in the expression of versican. Versican, a large proteoglycan, regulates water content of tissues, participates in the assembly of different ECM components and has important regulatory roles in cell biology ${ }^{6}$. The CPM is frequently exposed to physical and chemicals stressors ${ }^{4}$. Further, signs of muscle cell regeneration and degeneration in the CPM have been previously described by Cruse et al. ${ }^{15}$, probably also as a consequence of the act of swallowing over a life-time. These findings suggest the importance of endomysial fibronectin and versican to maintain muscle homeostasis and may explain the individual variance of these components observed in this study ${ }^{6,7}$.

We did not find any correlations among the density of the analyzed ECM components and the age, gender or smoking habits. Although our study presents one of the largest number of CPM histological samples ${ }^{1,3,4,15,16}$, we cannot exclude that it lacks the statistical power to detect differences. We used an automated image analysis system to quantify ECM components that avoided bias of subjective analysis.

The absence of changes on ECM components during aging could mean that CPM is not susceptible to age changes that are found in other skeletal muscles ${ }^{16}$. Immobilization and lack of activity that commonly affect aging skeletal muscle can account for increased amounts of certain ECM components, especially collagen. Type II muscle fibers (fast-twitch) appear to decrease with age, but this finding is not seen in the CPM ${ }^{16}$. CPM is always active, being tonically contracted or relaxed during swallowing, belching and vomiting. This behavior can stimulate ECM compounds to maintain their homeostasis as a training muscle.

In addition, qualitative alterations on ECM can overlap quantitative changes. In many organs, collagen changes with aging, qualitatively more than quantitatively. With aging, collagen solubility at $65^{\circ} \mathrm{C}$ decreases and there is an increase in cross-linking of the collagen macromolecules ${ }^{17}$. The 
aging process induces not only changes in the total amount of fibers, but changes in the relative proportion and structural alterations of elastic fibers components (length and tortuosity) ${ }^{18}$. These alterations could reduce the muscle viscoelastic properties, resulting in a stiffer structure on CPM and could be responsible for a less distensible muscle. Further studies analyzing ultra structural and biochemical studies on CPM in patients of different ages are needed.

\section{CONCLUSION}

In this study, novel information is presented about ECM composition of the CPM. Collagens had the highest density among the analyzed ECM components. The higher proportion of type I and III collagen and the elastic fibers arrangement can contribute for CPM elastic behavior. Variations in the expression of fibronectin and versican can be resultant of the active behavior of CPM. No clear histological differences in the ECM could be observed with age, sex and smoking habits. ECM components of CPM apparently work together to maintain tissue homeostasis.

\section{ACKNOWLEDGMENTS}

We thank the autopsy assistants of the SVOC-USP who helped in gathering the study material and Angela Batista Gomes dos Santos and Maria Cristina Rodrigues Medeiros for the support in the immunnohistochemical procedures. 


\section{REFERENCES}

1. Kristmundsdottir F, Mohon M, Froes MMQ, Cumming, WJK. Histomorphometric and histopathological study of the human cricopharyngeus muscle in health and in motor neuron disease. Neuropathol App Neurobiol. 1990; 16:461-75.

2. Järvinen TA, Józsa $L$, Kannus $P$ et al. Organization and distribution of intramuscular connective tissue in normal and immobilized muscles. $J$ Musc Res Cell Motil. 2002; 23:245-254.

3. Bonington A, Mahon M, Whitmore I. A histological and histochemical study of the cricopharyngeus muscle in man. J. Anat. 1988; 156:27-37.

4. Laurikainen E, Aitasalo K, Halonen P, Falck B, Kalimo H. Muscle pathology in idiopathic cricopharyngeus dysphagia. Enzime histochemical and electron microscopic findings. Eur Arch Otorhinolaryngol. 1992; 249:216-223.

5. Montes, GS. Structural biology of the fibers of the collagenous and elastic systems. Cell Biol Int. 1996; 20(1):15-27.

6. Buhler RB, Sennes LU, Mauad $T$ et al. Collagen fiber and versican distribution with the lamina propria of fetal vocal folds. Laryngoscope. 2007; 117: 1-4.

7. Hynes RO, Yamada KM. Fibronectins: multifunctional modular glycoproteins. J Cell Biol. 1982; 95:369-377.

8. Bradbury P, Rae K. Connective tissue and stains. In: Bancroft JD, Steves A, $4^{\text {th }}$ ed. Theory and practice of histological techiniques. New York, NY: Churchill Linvingstone; 1996:113-138.

9. Araújo BB, Dolhnikoff, Silva LF et al. Extracellular matrix components and regulators in the airway smooth muscle in asthma. Eur Res J. 2008; 32(1):61-69.

10. Shaker R, Kern M, Bardan E et al. Augmentation of deglutive upper esophageal sphincter opening in the elderly by exercice. Am J Physiol. 1997; 272:1518-22.

11. Kovanen $\mathrm{V}$. Effects of ageing and physical training on rat skeletal muscle. Acta Physiol Scand Suppl. 1989; 577: 1-56. 
12. Light $\mathrm{N}$, Champion AE. Characterization of muscle epimysium, perymisium and endomysium collagens. Biochem J. 1984; 219:1017-26.

13. Ross, R. The elastic fiber. J Histochem Cytochem. 1973; 21(3):199-208.

14. Gulati AK, Reddi AH, Zlewski, AA. Distribution of fibronectin in normal and regenerating skeletal muscle. Anat Rec. 1982; 204: 175-183.

15. Cruse JP, Edwards DAW, Smith JF, Wyllie, JH. The pathology of cricopharyngeal dysphagia. Histopathol. 1979; 3: 223-32.

16. Browlow $\mathrm{H}$, Whitemore I, Willian PLT. A quantitative study of the histochemical and morphometric characteristics of the human cricopharyngeus muscle. J Anat. 1989; 166:67-75.

17. Souza, RR. Aging of myocardial collagen. Biogerontology. 2002; 3: 325335.

18. Rodrigues CJ, Rodrigues Júnior, AJ. A comparative study of aging of the elastic fibers system of the diaphragm and the rectus abdominis muscles in rats. Braz J Med Biol Res. 2000; 33(12):1449-1454. 
Table I - Age distribution of subjects

\begin{tabular}{l|c|c}
\hline Age (years) & $\mathbf{N}$ & $\%$ \\
\hline$<40$ & 6 & 22.2 \\
\hline $40-50$ & 5 & 18.5 \\
\hline $50-60$ & 5 & 18.5 \\
\hline $60-70$ & 3 & 18.5 \\
\hline $70-80$ & 3 & 11.1 \\
\hline$\geq 80$ & 27 & 100 \\
\hline Total & & \\
\hline
\end{tabular}

$\mathrm{N}=$ number of cases, $\%=$ percentage 
Table II - Total collagen and elastic fibers (\%) in the cricopharyngeus muscle endomysium

\begin{tabular}{lcc}
\hline ECM component & Median & IQR \\
\hline Total collagen (\%) & 4.8 & 5.1 \\
\hline Elastic fibers (\%) & 2.6 & 1.9 \\
\hline = percentage; ECM = Extracellular matrix; IQR = Interquatile Range
\end{tabular}


Table III - Type I and type III collagen, fibronectin and versican (\%) in the cricopharyngeus muscle endomysium

\begin{tabular}{lcc}
\hline ECM component & Median & IQR \\
& & \\
\hline Type I collagen (\%) & 7.6 & 3.0 \\
\hline Type III collagen (\%) & 6.2 & 5.0 \\
\hline Fibronectin (\%) & 2.3 & 3.1 \\
\hline Versican (\%) & 2.8 & 3.4 \\
\hline = percentage; ECM = Extracellular matrix; IQR = Interquatile Range
\end{tabular}


Table IV - Spearman correlation analysis between age and extracellular matrix components density in cricopharyngeus muscle endomysium

\begin{tabular}{lcc}
\hline ECM component & Correlation & $\mathbf{p}$ \\
\hline Total collagen & 0.276 & 0.163 \\
\hline Elastic fibers & 0.253 & 0.201 \\
\hline Type I collagen & 0.166 & 0.407 \\
\hline Type III collagen & -0.001 & 0.994 \\
\hline Fibronectin & 0.038 & 0.847 \\
\hline Versican & 0.275 & 0.217 \\
\hline ECM = Extracellular matrix; $p=$ Significance &
\end{tabular}




\section{FIGURE LEGEND}

Figure A. Longitudinal histological section of H\&E-stained visualized under conventional light showing longitudional section of the CPM and the cricopharyngea mucosa (25x magnification). Figure B: Longitudinal histological section of the of cricopharyngeus muscle Picrosirius-stained. Notice large amounts of collagen fibers stained in a red dark color (25x magnification). Figure C: Cricopharyngeus muscle stained by oxidized Weigert resorcin-fuchisin in a 46 years male, showing transversally oriented thin fibers (arrows) perpendicular of the muscle cell, forming a fiber network (400x magnification). Figure D Elastic fiber netwok. Notice more dense aspect of the elastic fibers in muscle cell pole $\left(^{*}\right)$. Figure E: Immunnohistochemical technique for the Type I collagen (brown coloration) in a 68 year male, showing its distribution on endomysium (400x magnification). Figure F: Immunnohistochemical technique for the Type III collagen in a 28 year male, showing its distribution on endomysium (400x magnification) Figure G: Immunnohistochemical technique for the fibronectin in a 28 year male, showing endomisial distribution (400x magnification). Figure $\mathbf{H}$ : Immunnohistochemical technique for the fibronectin in a 71 year female, showing sarcolemal distribution (400x magnification). Figure I: Immunnohistochemical technique for the versican in a 37 year male, showing its rich endomisial distribution $(400 \mathrm{x}$ magnification). Figure $\mathrm{J}$ : Immunnohistochemical technique for the versican in a 28 year male, showing its poor endomisial distribution (400x magnification). 

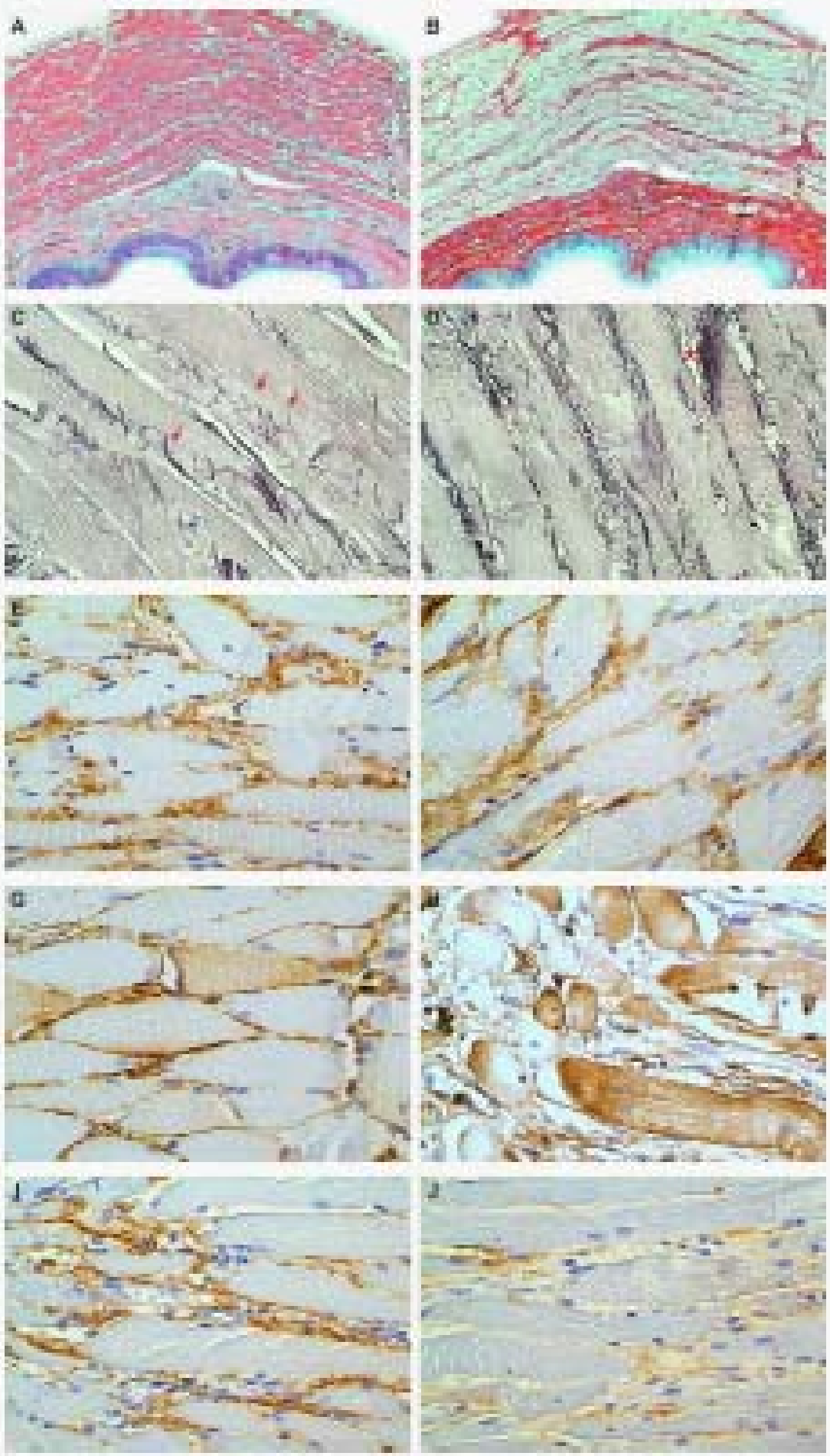

$167 \times 296 \mathrm{~mm}(300 \times 300$ DPI) 


\section{The Laryngoscope}

Extracellular matrix composition of the cricopharyngeus muscle Journal: The Laryngoscope

Manuscript ID: Iscope-09-1122

Wiley - Manuscript type: Original Study

Date Submitted by the Author: 10-Jul-2009

Complete List of Authors:

Tavares, Raquel; University of São Paulo, Otolaryngology

Sennes, Luiz; University of São Paulo, Otolaryngology

Mauad, Thais; University of São Paulo, Pathology

I mamura, Rui; University of São Paulo, Otolaryngology

Silva, Luis; University of São Paulo, Pathology

Carrau, Ricardo; University of Pittsburgh, Otolaryngology

Keywords - Combo: Dysphagia 


\section{LISTA DE FIGURAS}

Figura 1 Representação esquemática da transição faringoesofágica (visão lateral). $\mathrm{ClF}=$ músculo constrictor inferior da faringe, $\mathrm{CFo}=$ porção oblíqua do músculo cricofaríngeo, $\mathrm{CFh}=$ porção horizontal do músculo cricofaríngeo, $\mathrm{EC}=$ esôfago cervical, $\mathrm{CT}=$ músculo cricotireóideo, $\mathrm{CC}=$ cartilagem cricóide, $\mathrm{T}=$ traquéia (Modificado de Mu, 2001)

Figura 2 (A) Bloco laríngeo excisado de cadáver após a remoção das partes moles adjacentes. (B) Identificação da porção horizontal do músculo cricofaríngeo. (C) e (D) Remoção de fragmento da porção medial do MCF e sua mucosa adjacente

Figura 3 Sistema de análise de imagens composto por microscópio óptico Leica DMR (Leica Microsystems Wetzlar Gmb H, Alemanha) conectado a um computador tipo IBM por meio de uma câmera de vídeo JVC (JVC TK-C1380 Color Video Camera, Victor Company of Japan Limited, Japão)

Figura 4 Software Image Pro Plus ${ }^{\circledR}$ versão 4.1 (Media Cybernetics - Silver Spring, MD, EUA) com imagem capturada de uma lâmina estudada com coloração imunoistoquímica para colágeno tipo I no aumento de 400X

Figura 5 Aplicação do padrão de cor previamente estabelecido para colágeno tipo I obtendo-se a quantificação da expressão deste marcador (área marcada)

Figura 6 Medição da área total de interesse (área total) ............... 80

Figura 7 Distribuição dos casos estudados quanto raça ................ 83 
Figura 8 Corte histológico corado com método Hematoxilina e Eosina visualizado sob luz convencional, que mostra o músculo cricofaríngeo e sua mucosa adjacente (aumento de 250x). Observa-se a ausência de artefatos técnicos e inflamação local.

Figura 9 Cortes histológicos corados com método Picrossírius visualizados sob luz convencional, mostrando a diferença macroscópica na espessura das fibras musculares em indivíduo idoso (A) e em jovem (B) (aumento de 400x). Nota-se as fibras colágenas (vermelho) que revestem as células musculares individualmente

Figura 10 Corte histológico corado com método Picrossírius visualizado sob luz convencional que mostra a distribuição do colágeno total (vermelho escuro) no endomísio do músculo cricofaríngeo e sua mucosa adjacente (aumento de 250x)

Figura 11 Corte histológico corado pelo método resorcina-fuccina de Weigert após oxidação que mostra a rede de fibras elásticas no músculo cricofaríngeo (aumento de 400x). (A) Observa-se fibras elásticas delgadas envolvendo células musculares, que se ligam umas às outras por delgadas fibras em disposição transversal em relação à célula muscular (seta vermelha). (B) Fibras elásticas que se espessam na extremidade da célula muscular (asterisco vermelho)

Figura 12 Corte histológico corado pela técnica de imunoistoquímica que mostra a distribuição do colágeno tipo I (A) e colágeno tipo III (B) em coloração em marrom (aumento de 400x) 
Figura 13 Corte histológico corado pela técnica de imunoistoquímica para a fibronectina (em coloração em marrom). (A) mostra a distribuição endomisial e (B) a distribuição sarcolemal de alguns casos (aumento de $400 \mathrm{x}$

Figura 14 Corte histológico corado pela técnica de imunoistoquímica para a versican (em coloração em marrom). (A) mostra a distribuição endomisial e (B) a escassa distribuição em alguns casos (aumento de $400 x)$ 


\section{LISTA DE TABELAS}

Tabela 1 Distribuição de freqüências de faixa etária do grupo estudado

Tabela 2 Área porcentual do colágeno total e das fibras elásticas no músculo cricofaríngeo pelos métodos Picrossírius e Resorcina-fuccina oxidada de Weigert

Tabela 3 Teste $t$ de Student (de Mann-Whitney) para a comparação da área porcentual de colágeno total e das fibras elásticas entre os sexos

Tabela 4 Área porcentual dos elementos da matriz extracelular por imunoistoquímica

Tabela 5 Teste de Mann-Whitney para a comparação da área percentual dos elementos da matriz extracelular por imunoistoquímica entre os sexos

Tabela 6 Análise de correlação de Spearman entre a idade e as áreas porcentuais dos elementos estudados 


\section{LISTA DE ABREVIATURAS E SIGLAS}

$\begin{array}{ll}\text { CAPPesq } & \text { Comissão de Ética para Análise de Projetos de Pesquisa } \\ \text { CIF } & \text { músculo constritor inferior da faringe } \\ \text { EES } & \text { Esfíncter esofagiano superior } \\ \text { HC } & \text { Hospital das Clínicas } \\ \text { HC-FMUSP } & \text { Hospital das Clínicas e da Faculdade de Medicina da } \\ \text { HE } & \text { Universidade de São Paulo } \\ \text { MCF } & \text { Hematoxilina-eosina } \\ \text { SVOC } & \text { músculo cricofaríngeo } \\ \text { TF } & \text { Serviço de Verificação de Óbitos da Capital } \\ \end{array}$




\section{LISTA DE SÍMBOLOS}

$\begin{array}{ll}\mathrm{ms} & \text { milisegundos } \\ \mathrm{cm} & \text { centímetro } \\ \mathrm{h} & \text { hora } \\ \mathrm{mmHg} & \text { milímetros de mercúrio } \\ \mathrm{nm} & \text { nanometro } \\ \mathrm{X} & \text { vezes } \\ \% & \text { porcento } \\ \mu \mathrm{m} & \text { micrometro }\end{array}$




\section{RESUMO}

Tavares R.A. Estudo histológico da matriz extracelular do músculo cricofaríngeo em cadáveres de diferentes idades [tese]. São Paulo: Faculdade de Medicina, Universidade de São Paulo; 2009. 124p.

O músculo cricofaríngeo desempenha um importante papel na deglutição. Acredita-se que seu comportamento elástico seja dependente não apenas do componente muscular, mas também do tecido conectivo intramuscular. O objetivo desse estudo foi analisar a presença e a distribuição do colágeno total, colágenos tipo I e III, fibras elásticas, fibronectina e versican no endomísio do músculo cricofaríngeo em cadáveres de diferentes idades. Vinte e sete músculos foram obtidos mediante autópsia de indivíduos de ambos os sexos com idades entre 28 e 92 anos. Foram realizadas colorações histoquímicas, Método Picrossírius e Método Resorcina-fuccina com oxidação prévia pela oxona, e imunoistoquímicas, para colágeno tipo I, tipo III, fibronectina e versican. A medida dos elementos estudados foi feita por meio de um sistema de análise de imagens que incluía um microscópio, conectado a um computador por meio de uma câmera de vídeo. Foi utilizado o software Image pro Plus, versão 4.1. Para cada caso, quinze imagens não sobrepostas de cada coloração no aumento de 400x foram analisadas. A área de marcação positiva dentro do endomísio do músculo cricofaríngeo foi determinada por um padrão de cor específico para cada coloração. A área de cada elemento da matriz extracelular foi expressa como porcentagem da área total do estudada. Os dados foram expressos em medianas e intervalos interquartílicos. A correlação entre idade e os diferentes elementos da matriz extracelular foi realizada por meio da correlação de Spearman. O teste de Mann-Whitney para distribuição não paramétrica foi utilizado para comparar as áreas porcentuais e os indivíduos de diferente sexo. Todos os testes foram realizados pelo software SPPS versão 13.0 e foi admitido um calor de significância com $p<0,05$. O colágeno foi o elemento mais abundante dentre 
os estudados. Encontrou-se fibras elásticas longitudinais à fibra muscular, finas fibras transversais entre as fibras musculares e espessamento as fibras elásticas nos pólos da fibra muscular. Foi encontrada uma grande variação no conteúdo de fibronectina e versican entre os casos. Não foi evidenciada diferença estatisticamente significativa entre os elementos estudados, o sexo e a idade. Os resultados sugerem que a presença e distribuição desses elementos são importantes para a função do músculo cricofaríngeo e para a manutenção da homeostase. A porcentagem de colágeno encontrada é condizente com a característica esfinctérica do músculo e o arranjo de fibras elásticas contribui para o comportamento elástico e a capacidade de rapidamente reassumir a posição tônica após a abertura durante as deglutições. As variações da quantidade de fibronectina e versican, podem ser resultante da susceptibilidade a fatores agressores. A ausência de alterações com a idade pode significar que o músculo não esteja sujeito às mesmas alterações decorrentes da idade que outros músculos esqueléticos.

Descritores: 1.Esfíncter esofágico superior 2.Colágeno tipo I 3.Colágeno tipo III 4.Tecido elástico 5.Fibronectinas 6.Versicanas 7.Imunoistoquímica 


\section{SUMMARY}

Tavares R.A. Histological study of extracellular matrix of cricopharyngeus muscle in different ages [thesis]. São Paulo: Faculdade de Medicina, Universidade de São Paulo; 2009. 124p.

The cricopharyngeus muscle is thought to play an important role in swallowing and related activities. Its elastic behavior is likely to depend not only on its muscular components, but also on the intramuscular connective tissue. Our objective is to analyze the presence and distribution of total collagen, type I and III collagen, elastic fibers, fibronectin and versican in cricopharyngeus muscle endomysium in adults of a wide age range. Twentyseven cricopharyngeus muscles obtained from male and female cadavers (age range, 28-92 years-old) were analyzed with the Picrosirius method, oxidized Weigert resorcin-fuchisin, immunohistochemistry. Quantification of stained areas in the cricopharyngeus endomysium with different techniques was performed by an image analysis system connected to a light microscope. The correlation between age and the density of different extracellular matrix proteins was tested using Spearman test. T-tests for independent samples were used to analyze the influence of gender and smoking habit on the fractional areas of extracellular matrix. Collagens had the highest density among the analyzed components. Elastic fibers surrounded each muscle cell, longitudinal to their long axis, associated to traversing fibers, forming a fiber network embedding muscle cells. There was a wide variation on fibronectin and versican content among cases. There were no statistical significance for analysis made between those components of extracellular matrix and age andgender. Our findings suggest that presence and distribution of these extracellular matrix components are important to cricopharyngeus muscle homeostasis. The elastic fibers arrangement can contribute for the cricopharyngeus muscle elastic behavior and ability to rapidly reassume its tonic position after opening during swallows. Variations in the expression of fibronectin and versican can be 
resultant of its injury susceptibility. The absence of changes on extracellular components during aging could mean that cricopharyngeus muscle is not susceptible to similar age changes as other skeletal muscles.

Key-words: 1.Esophageal sphincter, upper 2.Collagen type I 3.Collagen type III 4.Elastic tissue 5.Fibronections 6.Versicans 7.Imunohistochemistry 
1 INTRODUÇÃO 


\section{INTRODUÇÃO}

A deglutição é um fenômeno complexo, cujo objetivo principal é o transporte seguro do alimento da boca ao estômago. Indivíduos normais deglutem cerca de 600 vezes por dia - 350 vezes enquanto estão acordados, 200 vezes durante as refeições e 50 vezes durante o sono (Kahrilas, 1994). Pode ser didaticamente dividida em fase oral, faríngea e esofágica (Santoro, 2002). A fase oral é voluntária e corresponde à manipulação e propulsão do bolo alimentar em direção à faringe. A deflagração do reflexo da deglutição marca o início da fase faríngea e involuntária da deglutição, que conta com importantes mecanismos de proteção das vias aéreas inferiores. Nesse ponto, a principal barreira que evita que o conteúdo oral deglutido ou que o conteúdo gástrico refluído atinja a via aérea inferior é o esfíncter esofagiano superior (EES). Alterações biomecânicas nessa região podem provocar quebra na eficiência da deglutição resultando em disfagia.

O músculo cricofaríngeo (MCF) é considerado o componente principal do EES e é estrutural, bioquímica e mecanicamente diferente da musculatura faríngea e esofágica que o circunda. Apresenta características únicas: é tonicamente ativo, possui grande capacidade elástica e é composto tanto de fibras de contração lenta quanto rápida. Essas características o capacitam a manter um tônus basal em repouso e a abrir mediante a deglutição da saliva e do bolo alimentar (Sivarao, Goyal, 2000). 
Esse comportamento elástico do MCF depende não apenas dos elementos contráteis musculares, mas também do tecido conjuntivo intramuscular (Järvinen, 2002).

O tecido conectivo dos músculos esqueléticos é formado por fibroblastos e seus produtos de secreção, que constituem seu componente principal - a matriz extracelular (Kovanen, 1989). Os componentes principais da matriz extracelular são classificados em estruturas fibrilares e não fibrilares. As proteínas fibrilares são representadas pelas fibras que constituem os sistemas colagênico (fibras colágenas e reticulares) e elástico (fibras elásticas maduras, elaunínicas e oxitalânicas). Já o componente não fibrilar da matriz extracelular, corresponde à substância fundamental amorfa, constituída principalmente pelos proteoglicanos, como o versican, e por glicoproteínas, como a fibronectina, além de água de solvatação.

Esses elementos conferem à matriz extracelular suas propriedades biomecânicas. Deste modo, o versican mantém a hidratação dos tecidos e da própria matriz mediante sua ligação com o ácido hialurônico. A fibronectina proporciona interação dos componentes da matriz entre si e entre as células, e é importante para a organização do citoesqueleto. A viscosidade tecidual, a elasticidade e a capacidade de suportar forças compressivas são suportadas pelos componentes da substância fundamental amorfa e a elastina presente nas fibras do sistema elástico. Por sua vez, o componente colagênico é responsável pela resistência às forças tênseis.

No que diz respeito ao MCF, pouco se sabe sobre os aspectos 
histológicos de sua matriz extracelular. Desconhecemos estudos que descrevam e quantifiquem componentes específicos da matriz extracelular na musculatura da transição faringoesofágica, notadamente na porção horizontal do MCF - principal componente do EES, bem como se existem alterações entre os sexos ou decorrentes do envelhecimento.

A grande maioria dos estudos histológicos realizados no MCF dá destaque ao tecido muscular por meio da utilização de colorações histoquímicas específicas para este tecido. Quando esses estudos abordam a matriz extracelular, quantificam-na apenas por exclusão do tecido muscular ou por colorações apenas para colágeno e que são pouco utilizadas na atualidade (Cruse, 1979; Hanna, Hhenderson, 1980; Bonigton et al., 1988; Brownlow et al.,1989; Kristmundsdottir et al., 1990; Laurikainen et al., 1992; Singh, Hamdy, 2005).

Não temos conhecimento do uso de colorações histoquímicas ou imunoistoquímicas para a quantificação do colágeno total, seus subtipos I e III, das fibras elásticas, da fibronectina e do versican no endomísio da porção horizontal do MCF, e, se existirem, quais são as variações de seu conteúdo com o decorrer da idade ou se são dependentes do sexo. 
2 OBJETIVOS 


\section{OBJETIVOS}

Tendo em vista a escassez de trabalhos na literatura sobre a composição da matriz extracelular do MCF e a importância desse conhecimento para a melhor compreensão da biomecânica da deglutição, os objetivos desse estudo são:

\section{Objetivo Principal:}

Avaliar a área porcentual do colágeno total, das fibras elásticas, do colágeno tipo I, tipo III, da fibronectina e do versican no endomísio do MCF.

\section{Objetivo Secundário:}

Verificar possíveis diferenças quantitativas em relação ao sexo e à idade nesses constituintes.

Para atingir esses objetivos estudamos fibras colágenas e elásticas por colorações histoquímicas e mais especificamente as isoformas I e III do colágeno, o versican e a fibronectina por imunohistoquímica. A quantificação desses elementos foi realizada por histomorfometria, utilizando-se um sistema de análise e processamento de imagens. 
3 REVISÃO DE LITERATURA 


\section{REVISÃO DE LITERATURA}

\subsection{A transição faringoesofágica e o músculo cricofaríngeo}

Como todos os esfíncteres do trato gastrointestinal, o EES separa dois segmentos funcionais (Hila et al., 2001). Fisiologicamente, é definido como uma zona de alta pressão intraluminal que separa a pressão atmosférica da faringe da pressão subatmosférica do esôfago. Também denominada de transição faringoesofágica (TFE), essa região corresponde às fibras do esôfago cervical e ao do músculo constritor inferior da faringe (CIF), formado pelos músculos tireoreofaríngeo (TF) e cricofaríngeo (CF) (Sivarao, Goyal, 2000; Costa, 2003; Singh, Hamdy, 2005).

\subsubsection{Anatomia do músculo cricofaríngeo}

A parede da faringe é composta principalmente por duas camadas musculares. Uma camada interna, longitudinal, e uma camada externa, circular que compreende três músculos constrictores, o constrictor superior, o médio e o inferior. O músculo CIF tem origem na linha oblíqua da cartilagem tireóide e na face lateral da cartilagem cricóide (Figura 1). Sua porção superior, ou parte tireofaríngea, origina-se na cartilagem tireóide e segue em sentido oblíquo e superior até se inserir na linha média posterior ou rafe fibrosa da faringe. Abaixo dele, e com menor espessura, identificamse dois outros fascículos musculares, que compõem a porção inferior do CIF 
ou parte cricofaríngea. O primeiro fascículo origina-se, bilateralmente, na borda lateral da cartilagem cricóide e se dirige em sentido posterior e superior até se encontrar com o fascículo oposto, constituindo a porção transversa ou superior do músculo cricofaríngeo. O outro fascículo, ímpar, origina-se dos dois lados, na borda posterolateral da cartilagem cricóide, e constitui a porção horizontal ou inferior do MCF (Gardner, 1988; Costa, 2003). Esta porção tem comprimento aproximado de $2,5 \mathrm{~cm}$ e extensão vertical de $0,7 \mathrm{~cm}$ a $1,7 \mathrm{~cm}(\mathrm{Mu}, 2002,2001)$.

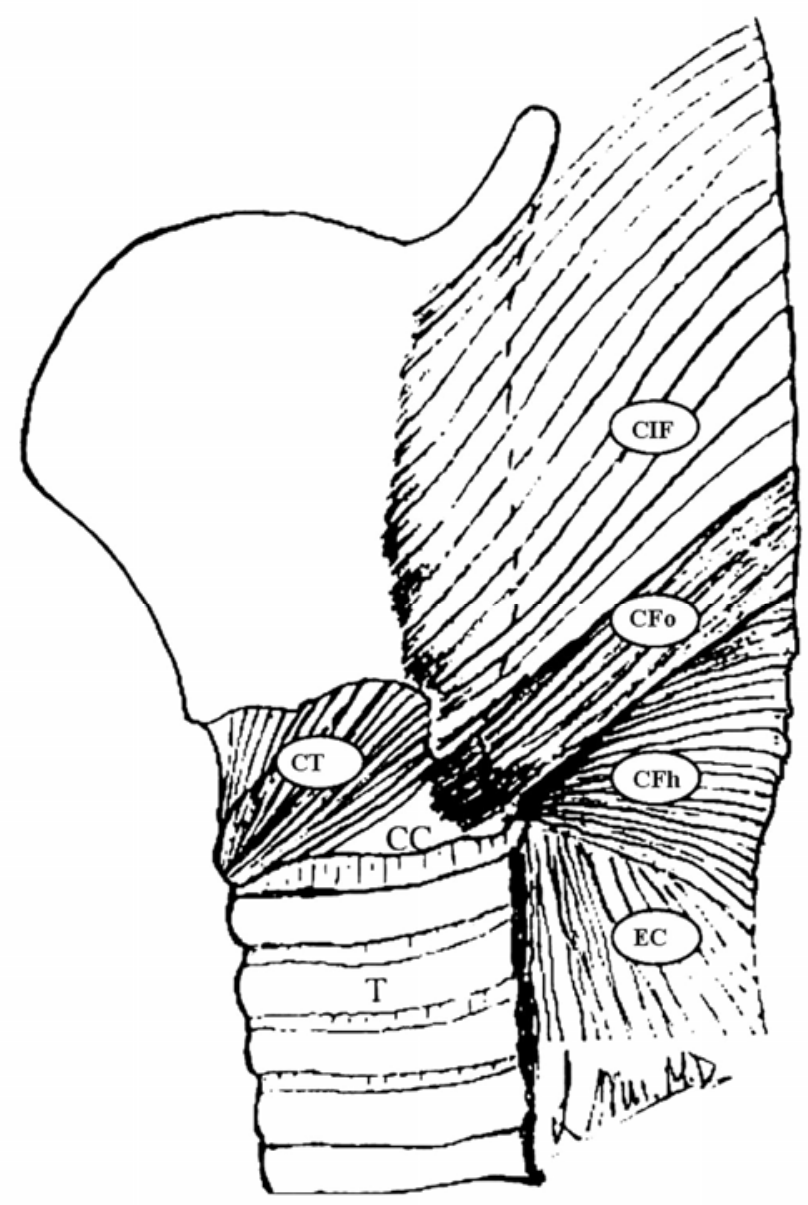

Figura 1 - Representação esquemática da transição faringoesofágica (visão lateral). CIF= músculo constrictor inferior da faringe, CFo $=$ porção oblíqua do músculo cricofaríngeo, CFh = porção horizontal do músculo cricofaríngeo, $\mathrm{EC}=$ esôfago cervical, $\mathrm{CT}=$ músculo cricotireóideo, $\mathrm{CC}=$ cartilagem cricóide, $\mathrm{T}=$ traquéia (Modificado de Mu, 2001) 
A porção horizontal do músculo cricofaríngeo é clinica e radiologicamente conhecida como "músculo cricofaríngeo" (Goyal et al., 1993). A primeira citação como entidade anatômica distinta foi feita por Valsalva, em 1717 (apud Lerche, 1950), mas o primeiro reconhecimento de sua função como esfíncter só ocorreu graças a estudos realizados por Home, em 1823 (apud Kirchner, 1958).

O MCF, embora não possua rafe mediana, é inervado bilateralmente e cada metade funciona como unidade motora distinta. A inervação motora, em sua porção inferior, é dada pelo nervo laríngeo inferior. A porção superior é inervada plexo faríngeo, formado pelo ramo faríngeo do nervo vago, pelo nervo laríngeo superior e pelo nervo glossofaríngeo. A inervação sensorial é transmitida pelo nervo glossofaríngeo e pelo nervo laríngeo superior. $\mathrm{O}$ controle central é, principalmente, ipsilateral (>95\%) e se processa no núcleo ambíguo da medula espinhal (Mu, Sanders, 1996; Sanders, Mu, 1998; Sivarao, Goyal, 2000; Singh, Hamdy, 2005).

\subsubsection{Fisiologia do músculo cricofaríngeo}

O EES atua como barreira entre a faringe e o esôfago, mantendo fechada essa região e abrindo-a fasicamente, durante alguns estados fisiológicos. Dessa forma, coordena a progressão de alimentos da faringe para o esôfago, previne a aerofagia e o refluxo de conteúdos esofageanos para a faringe e os pulmões (Lang, 1997).

No EES, as pressões basais de repouso em indivíduos normais vão de $35 \mathrm{mmHg}$ a 200mmHg (Goyal, Sivarao, 1999), e são diminuídas no sono, 
na infância e em idosos (Fulp et al., 1990; Goyal, Sivarao, 1999). Um aumento reflexo na pressão do esfíncter ocorre com a estimulação faríngea, com a distensão esofágica e com a infusão de ácido no esôfago, ou seja, sempre no sentido de proteger a região da entrada inadvertida de material estranho (Goyal, Sivarao, 1999).

Costa (2003) e Goyal et al. (1993) acreditam que a manutenção da pressão basal dessa região se deve à ação de pinça exercida pela relação entre a coluna cervical (quinta e sexta vértebras cervicais) e a laringe (cartilagem cricóide). Isso justificaria a assimetria das pressões dentro da região, pois a pressão anteroposterior é três vezes maior que a pressão laterolateral (Kahrilas et al., 1994).

A abertura da TFE ocorre por meio de três mecanismos que atuam de forma conjugada: a) o relaxamento do MCF; b) o efeito da complacência do componente muscular; e c) a tração da musculatura supra-hióidea. Anormalidades em um desses mecanismos causam diminuição da abertura da TFE durante a deglutição e incompleto clareamento do volume faríngeo deglutido, o que pode levar a aspiração pulmonar. Isso se torna ainda mais preocupante em idosos, porquanto apresentam, também, sensibilidade faringolaríngea reduzida. (Staff, Shaker, 2001).

\subsubsection{Histologia do músculo cricofaríngeo}

O MCF é composto por fibras musculares estriadas de tamanho variável, com diâmetro de $25 \mu \mathrm{m}$ a $35 \mu \mathrm{m}$. É formado tanto por fibras lentas (tipo I, oxidativas) como por fibras rápidas (tipo II, glicolíticas), porém com 
uma predominância de fibras lentas (mais de $80 \%$ ). A presença dos dois tipos de fibras capacita o músculo a manter um tônus basal constante e rapidamente relaxar em resposta a deglutição ou eructação (Sivarao, Goyal, 2000).

Existem poucos estudos sobre a histologia do MCF e nestes se observa uma abordagem quase exclusiva à pesquisa do tecido muscular.

Estudos no MCF em cobaias, realizados por Bonigton et al. (1987), evidenciam fibras musculares pequenas de tamanho uniforme com formato poligonal e núcleo periférico, que seguem um arranjo fascicular e sem fusos musculares. Em 1988, os mesmos autores descrevem um estudo em MCF humano com amostras obtidas em autópsias. Encontraram grande variação no tamanho das fibras musculares e grande quantidade de tecido conectivo endomisial entre os agrupamentos de músculo. Concluem que as fibras musculares se inserem numa trama de tecido conectivo.

Asoh e Goyal (1978) sugerem que essa trama de tecido conectivo seja responsável pela pequena pressão intraluminal residual $(10 \mathrm{mmHg})$ que se segue à secção do nervo motor do MCF em marsupiais. Goyal et al. (1993) afirma que essa pressão residual pode ser resultante de forças elásticas passivas que atuam sobre a parede do esfíncter. A presença dessa trama de suporte proporcionaria o mecanismo pelo qual o músculo se manteria tonicamente contraído e firmemente ancorado. A grande quantidade de tecido conectivo observada é compatível com a orientação circunferencial das fibras e a característica esfinctérica do músculo (Laurikainen et al., 1992). 
Alguns estudos sobre disfagia ou disfunção idiopática do cricofaríngeo (DIC) auxiliam o entendimento sobre o músculo, porque ainda hoje se dispõe de poucas informações sobre a sua estrutura normal. É difícil determinar dentre as características histológicas observadas no MCF quais são normais e quais são decorrentes de doenças propriamente ditas ou mesmo do processo de senescência. Além disso, o referido músculo guarda características histológicas distintas de outros músculos esqueléticos (Singh, Hamdy, 2005).

Ao estudar pacientes com DIC por meio de espécimes obtidos durante a miotomia do MCF para tratamento da disfagia, Cruse (1979) evidencia em seu grupo controle, alterações em fibras musculares (degeneração e regeneração), aumento da quantidade colágeno e infiltrado inflamatório crônico inespecífico. Acredita que essas alterações musculares sejam decorrentes do desgaste natural pelo ato de deglutir ao longo da vida.

Hanna e Henderson (1980) avaliam alterações histológicas em pacientes com DIC submetidos à miotomia. Observam as alterações ultraestruturais seguintes: mitocôndrias aberrantes, aumento do glicogênio, inclusões lipídicas, fagolisossomos e bastonentes de nemalina. Os autores acreditam que essas alterações possam ser secundárias à doença do refluxo gatroesofágico crônico.

Laurikainen et al. (1992), num trabalho sujeito a críticas metodológicas e estatísticas, estudam o MCF por microscopia eletrônica e histoquímica enzimática. Eles observam que a quantidade de tecido fibroso endomisial aumenta com a idade e é maior no MCF quando comparada a 
outros músculos esqueléticos. Os autores acreditam que essas alterações sejam decorrentes da característica excepcional do MCF de se manter contraído, a maior parte do tempo, e apenas temporariamente relaxado durante a deglutição. Além disso, o músculo é diretamente exposto a estresse físico e químico por causa de alimentos quentes e bebidas alcoólicas.

A prevalência de alterações do MCF, aparentemente, aumenta com a idade e tem sido observada em doenças neurológicas, particularmente na distrofia muscular oculofaríngea, em doenças de neurônio motor e em miopatias inflamatórias. Em 1990, Kristmundsdottir et al. conduzem um estudo sobre as características histopatológicas e histomorfométricas do MCF em pacientes sadios e portadores de doenças do neurônio motor. Observam grande quantidade de tecido conectivo endomisial e perimisial, com numerosas fibras elásticas e depósitos gordurosos. Verificam, ainda, que nos sujeitos normais, a média de componentes não musculares varia de 28 a $53 \%$, com conteúdo de gordura entre 0 e $10 \%$.

\subsection{Ação do envelhecimento e do sexo}

\subsubsection{Sobre a deglutição}

Muitas alterações que comprometem a eficiência da deglutição orofaríngea ocorrem com o envelhecimento. Algumas delas são decorrentes do efeito direto da senescência, outras de doenças associadas e mesmo de 
medicações utilizadas no tratamento dessas doenças. Sabe-se que as alterações na deglutição, decorrentes do envelhecimento, atingem o sistema aferente, o controle central e o sistema eferente (McComas et al., 1973), e alteram todas as fases da deglutição orofaríngea.

A maioria dos autores concorda que, com o avanço da idade, a capacidade de abertura do MCF diminui (Cook, 1993). Dejaeger et al. (1994) verificam que os idosos apresentam, com maior freqüência, incompleto relaxamento do EES e estase salivar de bário líquido em valéculas e seios piriformes, após as deglutições. Achados semelhantes foram encontrados por Shaw et. al (1995). Estes últimos verificam significativa diminuição da abertura do EES e concluem que a incapacidade do EES envelhecido em distender, durante a passagem de o bolo alimentar, é compatível com a diminuição da complacência muscular advinda da idade.

McKee et al. (1998) avaliam a influência do sexo e da idade na onda de pressão faríngea. Os resultados indicam que a idade está diretamente associada a uma redução da resposta da faringe na deglutição, diminuição da abertura do EES e redução em sua pressão de repouso. Esse estudo não estabelece um padrão de diferença em relação ao sexo.

Contrariando os achados anteriores, Robbins et al. (1992) não encontram diferenças significativas dos valores de pressão do EES em diferente grupos etários. Eles estudam o efeito do envelhecimento normal na deglutição orofaríngea num grupo de indivíduos de diferentes sexos e idades, simultaneamente, por videofluoroscopia e manometria. Verificam que idosos apresentam um tempo total aumentado de deglutição orofaríngea e 
maior duração na abertura do EES.

3.2.2 Sobre o tecido muscular esquelético e sua matriz extracelular

Alterações desfavoráveis ocorrem no músculo esquelético com a senescência. $O$ processo do envelhecimento é acompanhado pela diminuição da função muscular decorrente da perda da massa, da capacidade de estiramento e da força do músculo (Chow et al., 2005; Volpi et al., 2004).

Estudos em autópsia sobre a composição de fibras musculares no músculo vasto lateral mostram perda de fibras musculares a partir da quarta década de vida, preferencialmente de fibras tipo II (Lexel et al., 1988; Kovanen, 1989). Não obstante, a massa muscular não é o único determinante da função muscular. Segundo MacClenna et al. (1980), parte das alterações musculares que ocorrem com o envelhecimento pode ser decorrente da substituição do tecido muscular por tecido conjuntivo. Os componentes do tecido conjuntivo mudam com a idade e exercem influência sobre comportamento celular (Labat-Robert et al., 2000).

Tanto o envelhecimento quanto o tipo de atividade física levam a alterações quantitativas e qualitativas nas propriedades do tecido conjuntivo em órgãos (Kovanen, 1989). A biossíntese de colágeno, por exemplo, diminui com uma atividade muscular menor porque depende do equilíbrio entre produção e consumo de proteínas (Takala, Virtanen, 2000).

O MCF mantém-se tonicamente contraído, exceto nos episódios de deglutição, vômito e eructação. Por apresentar essa alta taxa de atividade 
obrigatória, à semelhança da musculatura respiratória, no MCF as alterações decorrentes do desuso são praticamente eliminadas e os efeitos decorrentes do envelhecimento são mais evidentes (Rodrigues, 1994; Lang, 1997).

\subsection{O tecido conjuntivo}

\subsubsection{Aspectos gerais}

Os tecidos conjuntivos são estruturas biológicas complexas formadas por uma variedade de componentes químicos distintos e contêm células próprias (fibroblastos, osteoclastos e condrócitos) e células relacionadas com a função imunológica (polimorfonucleares, macrófagos e mastócitos), vasos sangüíneos, nervos, além de seu principal e mais abundante componente, a matriz extracelular (Parry, Craig, 1988).

Nas últimas décadas, o conhecimento sobre a biologia molecular da matriz extracelular tem aumentado exponencialmente. Para propósitos didáticos, as macromoléculas isoladas de tecidos conectivos de diferentes espécies animais, desde invertebrados a humanos, podem ser divididas em quatro grandes categorias: a) colágenos; b) elastinas; c) proteoglicanos; e, d) glicoproteínas. As duas primeiras famílias formam o arcabouço fibroso, enquanto os proteoglicanos e glicoproteínas preenchem os espaços intersticiais (Lobat-Robert, 1990).

Além de fornecer suporte estrutural para os tecidos, a matriz extracelular é meio pelo qual transitam informações entre as células, que por 
sua vez são responsáveis por processos como morfogênese, diferenciação e migração celulares, reparo e fibrose tecidual. As diversas concentrações e associações dos componentes da matriz extracelular resultam em adaptações específicas para determinados órgãos, permitindo a manutenção da homeostase, diferenciações celulares em cada estágio da vida e adaptações frente a diferentes estímulos (Montes, 1996).

\subsubsection{O sistema de fibras colágenas}

O termo colágeno refere-se a uma família de proteínas fibrosas encontradas em todos os animais multicelulares. É a mais abundante proteína fibrosa extracelular dos seres humanos, formando cerca de $25 \%$ de todas as suas proteínas (Takala, Virtanen, 2000) e um a 9\% da massa não gordurosa do músculo esquelético (Kovanen, 1989; Sousa, 2002).

A principal característica da molécula de colágeno típica é a estrutura longa e rígida em tripla fita helicoidal na qual, três cadeias peptídicas de colágeno, chamadas cadeias $\alpha$, estão enroladas entre si (Alberts et al., 2002). Essas moléculas podem agrupar-se em polímeros ordenados chamados fibrilas de colágenos, que por sua vez podem se agrupar em fibras mais grossas, as fibras colágenas.

As moléculas de colágeno são sintetizadas no retículo endoplasmático rugoso. Seguem para o aparelho de Golgi, onde sofrem modificações, incluindo a hidroxilação dos resíduos de prolina e lisina, para formar, respectivamente, a hidroxiprolina e a hidroxilisina, e a glicosilação enzimática da hidroxilisina. A hidroxilação da prolina é essencial para a 
estabilidade térmica da tripla hélice. A hidroxilação da lisina proporciona substrato para a sua posterior glicosilação e formação de ligações cruzadas estáveis, importantes para a aquisição da força tênsil do tecido. (Michelacci, 2003)

Os produtos dessas reações químicas são, então, secretados no espaço extracelular com extensões carboxila e amina terminais que constituem uma molécula chamada procolágeno. Após a exocitose, procolágeno peptidases removem as extensões carboxila e amina terminais. A proteína resultante é chamada tropocolágeno, que se polimeriza em filamentos longos no meio extracelular. Essas moléculas sofrem oxidações pela ação da lisil oxidase, originando aldeídos nas porções terminais e nas porções helicoidais da molécula. Esses aldeídos formam ligações covalentes intra- e intermoleculares entre as cadeias $\alpha$, permitindo a formação de múltiplas ligações cruzadas entre as moléculas de colágeno, levando à formação de fibras estáveis (Melo, 2004).

A concentração de colágeno, presente no espaço extracelular, é controlada antes e após a sua secreção. A renovação do colágeno intracelular - o procolágeno - é dependente da relação entre a síntese e a taxa de degradação. No espaço extracelular, a tripla hélice de colágeno é fragmentada pela ação das metaloproteinases (MMPs), ou colagenases, e esses fragmentos são degradados por proteinases. As MMPs são uma família de endopeptidases que, coletivamente, são capazes de degradar todos os componentes da matriz (Kovanen, 2002).

Estruturalmente, existem três componentes na trama colagenosa do 
músculo esquelético. O epimísio é o tecido conectivo que circunda todo o músculo, o perimísio circunda grupos de células musculares e o endomísio circunda, individualmente, cada miócito (Salonen et al., 1985; Souza, 2002).

No músculo esquelético, o colágeno se apresenta, principalmente, em três formas fibrilares: I, III e V, e uma forma não fibrilar, o colágeno tipo IV. Os colágenos do tipo I e III são os mais abundantes. Segundo Kurosu (1979), o tipo I corresponde a $80 \%$ e o tipo III a $19 \%$, além disso, colágenos tipos II, XI, XIII, XIV, XV e XVIII também têm sido encontrados no músculo esquelético e o colágeno tipo VI no músculo cardíaco (Takala, Virtanen, 2000).

O colágeno tipo I é o mais comum em todos os tecidos, não apenas no músculo esquelético. Constitui $90 \%$ do colágeno no organismo e forma fibras colágenas no osso, dentina, cemento, tendões, fáscias, cápsulas de órgãos, ligamentos e na região profunda da derme. Sua principal função é proporcionar resistência à tensão, graças à suas grossas fibras densamente empacotadas e de diâmetro heterogêneo (50nm a 60nm) (Montes, 1996; Souza, 2002).

O colágeno tipo III, geralmente co-distribuído com o colágeno tipo I, está presente em órgãos e tecidos que precisam de arcabouço estrutural variável, como a região superficial da pele, a camada média dos vasos sangüíneos, a mucosa dos órgãos do trato digestório, respiratório e reprodutor e em órgãos parenquimatosos. Durante os processos de reparo e nas fibroses em geral, o colágeno tipo III é o primeiro a ser depositado, e posteriormente é substituído pelo tipo I nas regiões sujeitas às grandes 
forças de tensão. O colágeno tipo III forma fibrilas de $35 \mathrm{~nm}$ a $55 \mathrm{~nm}$ de diâmetro, frouxamente empacotadas, com grande quantidade de substância amorfa entre si, e forma fibras frouxas e flexíveis de $0,5 \mu \mathrm{m}$ a $2 \mu \mathrm{m}$ de diâmetro conhecidas como fibras reticulares (Montes, 1996).

O colágeno é um material resistente, com grande força tênsil. Essa característica depende de muitos fatores, incluindo sua concentração no tecido, seu alinhamento espacial, o diâmetro das fibras e dos tipos de colágeno (Souza, 2002). As diferentes propriedades dos diferentes tipos de colágeno, dentro do músculo esquelético, capacitam cada um a desempenhar uma função específica (Kovanen et al., 1987).

\subsubsection{Métodos histológicos para o estudo do colágeno}

Existem diversos métodos histológicos para a detecção do colágeno nos tecidos (Montes, Junqueira, 1991), dentre eles, o método Picrossírius e a imunohistoquímica contribuíram significativamente para uma melhor compreensão da função e patologia do colágeno.

As colorações tricromo pelos métodos Mallory, Masson e van Giesen, embora bastante utilizadas no passado, não são os métodos ideais para a detecção de colágeno, pois não identificam fibras reticulares (colágeno tipo III), nem o colágeno das membranas basais (colágeno tipo IV) (Montes, 1996).

O método Picrossírius baseia-se na coloração tecidual por um corante ácido, o Sirius Red. As moléculas de colágeno, que são ricas em aminoácidos básicos, reagem fortemente com corantes ácidos como o Sirius 
Red. Além desta forte reação, a molécula deste corante é longa e promove intensificação da birrefringência natural do colágeno, pelo fato de muitas das moléculas do corante se alinharem paralelamente ao eixo longitudinal de cada molécula de colágeno (Montes, Junqueira, 1991). Por essa técnica, o colágeno adquire uniformemente a cor vermelha, tornando possível definir sua distribuição.

Os métodos imunohistoquímicos, usando anticorpos específicos, têm sido utilizados para determinar os tipos de colágeno presentes na matriz extracelular (Souza, 2002) e fornecem quantificações mais fidedignas, e baseiam-se numa reação antígeno-anticorpo. Para a identificação de uma proteína (antígeno) específica, seu determinado anticorpo reconhecerá seu domínio levando a reação positiva final à coloração acastanhada.

\subsubsection{Ação do envelhecimento sobre o sistema de fibras colágenas}

Alterações relacionadas com a idade, na distribuição das fibras colágenas em diversos órgãos, têm sido estudadas de modo amplo e apresentam resultados conflitantes. No entanto, a maioria dos autores concorda que essas alterações estão muito mais relacionadas ao estado de agregação da molécula e à organização tecidual das fibras de colágeno do que às alterações quantitativas.

Segundo Sousa (2002), o colágeno em muitos órgãos incluindo tendões, músculos e pulmões, sofre alterações tanto quantitativas como qualitativas com o avançar da idade. Em muitos tecidos ocorre um aumento na quantidade de colágeno total, sua solubilidade à temperatura de $65^{\circ} \mathrm{C}$ 
diminui e a estabilidade da estrutura aumenta. Isto resulta do aumento das ligações cruzadas entre suas moléculas, tornando-o mais estável, rígido e resistente às colagenases.

De acordo com Mohan e Radha (1980) e Alnaqeeb (1984) a quantidade de colágeno aumenta muito com a idade. $\mathrm{O}$ aumento na concentração de colágeno intramuscular ocorre no endomísio e no perimísio, tanto em músculos lentos quanto em músculos de contração rápida.

Dantas (2009) estuda a matriz extracelular do músculo constrictor superior da faringe em indivíduos com Síndrome da Apnéia Obstrutiva do Sono por meio de histomorfometria utilizando um sistema de análise e processamento de imagens, e encontra uma correlação positiva significante entre a idade e o colágeno tipo I, e uma correlação negativa entre a idade e o colágeno tipo III no músculo constrictor superior da faringe.

Apesar das evidências observadas em diversos experimentos, Haus et al. (2007) acreditam que as variações na quantidade de colágenos nos tecidos ao longo da vida, e que a idade não tem efeito na concentração de colágeno intramuscular. Os pesquisadores constatam que tanto a concentração de colágeno endomisial quanto as ligações cruzadas mediadas enzimaticamente são pouco afetadas pela idade. No entanto, as ligações cruzadas não enzimaticamente mediadas estão aumentadas nos músculos de indivíduos idosos.

\subsubsection{O sistema de fibras elásticas}

Nos animais vertebrados a propriedade elástica resulta de uma 
estrutura complexa e rica em proteínas, presente no tecido conjuntivo de diferentes órgãos. Esta estrutura, denominada fibra elástica, forma na matriz extracelular uma rede que permite que determinados tecidos sofram expansão e retração sem lesão tecidual ou gasto de energia (Rosenbloom et al., 1993).

As fibras elásticas podem ser encontradas nos pulmões (Mauad et al., 1996), na pele (Cotta-Pereira et al., 1976), no músculo esquelético (Rodrigues, Rodrigues Júnior, 2000), no músculo liso das artérias (Kielty, 2002), no músculo cardíaco (Carvalho Filho et al., 1996) e em outros órgãos. Elas são compostas por duas macromoléculas distintas: um componente amorfo, mais abundante e caracterizado pela elastina, e outro, microfibrilar, caracterizado pela fibrilina (Carvalho, 2001).

A elastina é uma proteína extremamente hidrofóbica que, como o colágeno, é rica em prolina e em glicina não glicosidada. A elastina contém também alguma hidroxiprolina, é desprovida de hidroxilisina (Alberts, 2002), extremamente resistente à dissolução, estável em condições fisiológicas e permanece nos tecidos por todo o tempo de vida do organismo (Shapiro et al., 1991).

Durante a elastogênese, a elastina é secretada para o meio extracelular em sua forma monomérica, a tropoelastina. Esse processo é mediado por um receptor de superfície, a proteína de ligação da elastina (Merrilees et al., 2008). Uma vez no espaço extracelular, e próximo à membrana plasmática, as moléculas de tropoelastina se polimerizam, por meio de ligações cruzadas entre os resíduos de lisina, catalisadas pela lisil 
oxidase, dando origem à elastina (Rosenbloom et al., 1993).

A fibrilina é uma glicoproteína que apresenta como característica marcante um grande número de resíduos de cistina. Estes resíduos estão envolvidos na formação de pontes dissulfeto que estabilizam a molécula, criando uma conformação ideal para a formação das microfibrilas. Além das pontes dissulfeto, existem ligações cruzadas entre resíduos de ácido glutâmico que tornam as microfibrilas extremamente insolúveis (Carvalho, 2001)

As microfibrilas são lançadas no meio extracelular por fibroblastos, por células mesenquimais e por outras células e servem de arcabouço para a deposição de elastina (Ross, 1973). São geneticamente designadas para manter sua função ao longo da vida, entretanto, MMPs chamadas elastases e proteases séricas são capazes de degradá-las (Kielty, 2002).

Elastina e fibras elásticas são termos diferentes. A fibra elástica é a estrutura complexa encontrada na matriz extracelular que contém elastina, proteínas microfibrilares, lisil-oxigenase e proteoglicanos. Já a elastina é a proteína predominante em uma fibra elástica madura, sendo responsável por sua propriedade mecânica característica de recolhimento elástico (Nita, 2008).

O sistema de fibras elásticas é formado por três tipos de fibras. O primeiro componente formado é a fibra oxitalânica, composta por microfibrilas sintetizadas e secretadas no meio extracelular. Estas microfibrilas estão dispostas em feixes paralelos, indicando a direção e a forma da futura fibra elástica (Rosenbloom et al., 1993). Em seguida, 
pequena quantidade de substância amorfa, a elastina, é aderida, formando o segundo componente do sistema elástico: a fibra elaunínica. Com a adição de maior quantidade de elastina (que pode chegar a $90 \%$ ) a fibra torna-se espessa e forma-se a fibra elástica madura. A presença dos três componentes do sistema de fibras elásticas nos tecidos indica uma elastogênese normal (Pecora et al., 2001).

A elasticidade tecidual é primariamente dependente da quantidade de fibras elásticas maduras e elaunínicas, enquanto a resistência tecidual é dada pelas fibras oxitalânicas (Rodrigues, Rodrigues Júnior, 2000). A quantidade dos três tipos varia entre os diferentes tecidos e parece depender de sua função e do envelhecimento (Pecora et al., 2001).

\subsubsection{Métodos histológicos para o estudo das fibras elásticas}

Várias colorações podem ser aplicadas para o estudo das fibras elásticas. O método da hematoxilina-férrica ou Verhoeff reconhece apenas fibras elásticas maduras (que possuem grandes quantidades de elastina) e não é adequado para a identificação das fibras elaunínicas e as oxitalânicas. A coloração resorcina-fucsina de Weigert é mais sensível e também cora as fibras elaunínicas, além das elásticas maduras. Quando acrescido do processo de oxidação pela oxona (Resorcina-fucsina oxidada), esta última coloração é capaz de identificar também as fibras oxitalânicas (Rodrigues, 1994; Montes, 1996).

\subsubsection{Ação do envelhecimento sobre o sistema de fibras elásticas}

Segundo Kielty et al. (2002) a perda da elasticidade por alterações 
degenerativas é o principal fator para o envelhecimento do tecido conectivo, e pode resultar no desenvolvimento de aneurismas aórticos, de enfisema pulmonar e de alterações na pele decorrentes da exposição solar.

Sabe-se que a elasticidade característica das fibras elásticas maduras é graças, em parte, às interações hidrofóbicas que estabilizam sua estrutura. Isso explica também a grande afinidade para lípides e cálcio. A deposição desses elementos nas fibras elásticas maduras, durante o envelhecimento, e a arteriosclerose leva à perda da elasticidade dos vasos (Labat-Robert et al., 1990).

Rodrigues e Rodrigues Júnior (2000) estudam as alterações relacionadas ao envelhecimento no sistema de fibras elásticas dos músculos diafragma e reto abdominal de ratos de diferentes idades. Constatam que a densidade das fibras elásticas maduras e elaunínicas aumenta progressivamente com a idade enquanto a das fibras oxitalânicas diminui. No entanto, apesar de possuírem maior densidade, as fibras maduras e elaunínicas apresentam uma arquitetura distorcida que se traduz em feixes espessos, tortuosos e fragmentados. Essas alterações causam diminuição da elasticidade original do tecido muscular.

Carvalho Filho et al. (1996) estudam fibras elásticas maduras pelo método de Vehoeff em músculos cardíacos de indivíduos com idades diferentes e percebem que a extensão e a espessura das fibras se mantêm constantes desde o nascimento até a idade adulta, e aumentam apenas após a terceira década de vida. Os autores acreditam que essas alterações podem resultar na diminuição da elasticidade e na perda da pressão de 
recolhimento elástico ventricular com o avanço da idade.

\subsubsection{A fibronectina}

A matriz extracelular contém diversas proteínas não colagenosas que tipicamente apresentam múltiplos domínios, cada um deles com sítios de ligação específicos para macromoléculas da matriz e para receptores da superfície celular. Essas proteínas contribuem para a organização da matriz extracelular bem como para a adesão celular, além de guiarem o movimento das células durante o desenvolvimento tecidual, seja atraindo-as ou afastando-as. Essa classe de proteínas é vital para a homeostase dos tecidos e seu primeiro componente a ser descrito foi a fibronectina (Alberts et al., 2002).

A fibronectina é uma glicoproteína que tem sido implicada em vários processos celulares, principalmente os que envolvem interações de células com materiais extracelulares, como adesão celular, organização do citoesqueleto, migração, diferenciação, transformação oncogênica e homeostase. É produzida, principalmente, por fibroblastos e células endoteliais, mas também por outros tipos celulares em menor quantidade. A sua molécula é assimétrica e consiste em duas subunidades de mesmo peso molecular, que estão unidas entre si por pontes dissulfeto (Hynes, Yamada, 1982).

A proteína pode ser encontrada em fluidos corporais, principalmente no plasma, no tecido conectivo da matriz extracelular e na maioria das membranas basais. Apresenta duas formas: uma plasmática e solúvel e 
outra menos solúvel, no tecido conectivo frouxo (Hynes, Yamada, 1982). No tecido conectivo do músculo esquelético, a fibronectina pode ser identificada como uma fina e contínua camada no endomísio, perimísio e epimísio (Salonen et al. 1985). Uma característica importante da fibronectina é sua capacidade de interagir com uma ampla variedade de macromoléculas e, em virtude de sua alta afinidade com o colágeno, encontra-se codistribuída a ele.

Foidart et al. (1981) estudam, por imunofluorecência, a distribuição dos colágenos tipo I a IV, do pró-colágeno tipo I e III e da fibronectina em músculo esquelético de indivíduos sadios e indivíduos com dermatomiosite e polimiosite. Verificam que nos indivíduos sadios, os colágenos tipo I e III, seus procolágenos e a fibronectina encontram-se no endomísio e perimísio. Nos pacientes com miopatias ocorre aumento da fibrose endomisial e perimisial, e acúmulo do colágeno tipo I, tipo III e da fibronectina.

Salonen et al. (1985) avaliam a distribuição do colágeno tipo I, III, V e fibronectina por imunofluorescência em músculo esquelético de ratos após denervação. Observam um aumento dos colágenos tipos I, III e da fibronectina no endomísio e no perimísio, e sugerem que a atrofia por denervação em músculos é acompanhada por alterações fibróticas.

Gulati et al. (1982) investigam possíveis alterações da fibronectina durante a regeneração muscular induzida por autotransplante. Por meio da imunofluorescência indireta, verificam que no músculo esquelético de ratos sadios, a fibronectina é encontrada no endomísio e é ausente no sarcolema. Após o autotransplante observam uma diminuição da fibronectina endomisial 
e um aumento da fibronectina sarcoplasmática.

Como a fibronectina desempenha papel importante nas interações célula-matriz, o aumento de sua produção com a idade pode causar alterações teciduais (Robert, Labat-Robert, 2000).

Boyer et al. (1991) estudam culturas de pele de ratos de diferentes idades a fim de avaliar as alterações dependentes da idade na biossíntese da fibronectina e dos colágenos fibrosos, tipos I e III. Constatam que a biossíntese da fibronectina e colágeno tipo III aumenta progressivamente com a idade. Sugerem, assim, que a expressão dos genes que codificam as macromoléculas da matriz sofre regulação dependente da idade, e que esta regulação é diferente para as diferentes macromoléculas.

Delpuech et al. (1988) avaliam a influência do sexo e da idade na concentração de fibronectina plasmática. Verificam forte correlação entre idade e níveis séricos de fibronectina, observando a duplicação da concentração ao longo da vida. Em mulheres detectam um aumento linear e em homens exponencial.

\subsubsection{O versican}

Proteoglicanos são estruturas moleculares compostas por ao menos uma cadeia de glicosaminoglicanos ligada covalentemente a uma cadeia central de proteína (Ruoslahti, 1988).

Glicosaminoglicanos são carboidratos formados por uma estrutura dissacarídica básica e repetitiva, possuem cadeias lineares de comprimento variável e apresentam cargas negativas em razão da presença de radicais 
carboxílicos ou carboxílicos sulfatados. A presença dessas cargas garante a essas moléculas grande parte de suas características funcionais, como a associação a uma grande quantidade de cátions livres retendo assim água nos tecidos, interagindo com outros componentes da matriz extracelular e com fatores de crescimento (Carvalho et al., 2001). A proteína central também apresenta domínios que permitem a interação com outros açúcares (como o ácido hialurônico), com proteínas diversas (como colágeno) e com as membranas celulares.

Os proteoglicanos estão relacionados com uma grande variedade de processos metabólicos celulares tais como: a adesão celular, a migração celular, a regulação de fatores teciduais de crescimento, a regulação de fatores imunológicos, a ligação com proteínas plasmáticas e o controle de trombogênese (MacCarthy et al., 1989). Regulam ainda a fibrilogênese do colágeno e das fibras elásticas (Yoon, Halper, 2005; Merrillees, 2008)

Os proteoglicanos podem ser classificados de acordo com os tipos de glicosaminoglicanos, que são divididos em vários grupos: keratan sulfato, condroitin sulfato, dermatan sulfato, heparan sulfato. O ácido hialurônico difere das outras glicosaminoglicanos porque não possui ligação covalente com a proteína (Lander et al., 1993).

O versican pertence à família condroitin sulfato e esse nome remete à grande diversidade de ações biológicas dessa molécula. Como o agrecan, o neurocan e o brevican, são compostos formados por uma proteína central com domínios globulares e glicosaminoglicanos com domínios condroitin sulfatos. Um desses domínios reconhece e liga-se especificamente ao ácido 
hialurônico, com alta afinidade, retendo assim água nos tecidos e mantendo a matriz extracelular hidratada. Esses agregados podem modular a adesão, a migração e a proliferação celulares (Hardingham, Fosang, 1992; BodeLesniewska et al., 1996; Sorrel et al., 1999). O versican apresenta quatro diferentes isoformas V0, V1, V2 e V3 (Wight, 2002).

O versican está presente no tecido conectivo de vários órgãos, freqüentemente associados à trama de fibras elásticas, colágenas e também à fibronectina. Apresenta expressão fisiológica no músculo liso, nas cartilagens fibrosa e elástica, no sistema nervoso central e periférico, no epitélio glandular, nos vasos sangüíneos, pele e na lâmina própria da prega vocal de fetos. No músculo estriado esquelético é encontrado no endomisio, no perimisio e no epimísio (Bode-Lesniewska et al., 1996; Pukkila et al., 2004; Buhler et al., 2008).

Carrino et al. (2000), ao estudar alterações relacionadas com a idade nos proteoglicanos da pele humana, observam uma diminuição da proporção de versican e um aumento da proporção de decorina, um pequeno dermatan sulfato, em função da idade. Observam, ainda, alterações estruturais na molécula desses proteoglicanos na pele das diferentes idades estudadas e postulam que essas diferenças podem justificar, pelo menos em parte, as mudanças na hidratação e na resistência da pele nos idosos. Sorrel et al. (1999) verificam que a pele fetal tem uma proporção significativamente maior de versican do que a pele adulta, além de apresentar um padrão diferente de distribuição. 
4 MÉTODOS 


\section{MÉTODOS}

\subsection{Aspecto ético}

A pesquisa foi aprovada sob o protocolo de número 604/05 pela Comissão de Ética para Análise de Projetos de Pesquisa (CAPPesq) da Diretoria Clínica do Hospital das Clínicas e da Faculdade de Medicina da Universidade de São Paulo (HC-FMUSP) (Apêndice).

\subsection{Casuística}

\subsubsection{Seleção da amostra}

Foram coletados blocos anatômicos contendo a TFE excisados de 27 cadáveres no Serviço de Verificação de Óbitos da Capital (SVOC). Os indivíduos avaliados eram vítimas de morte súbita procedentes do HCFMUSP, de outros hospitais ou da própria residência. A coleta realizou-se no período de janeiro de 2006 a janeiro de 2008 .

Foram incluídos apenas cadáveres cujo MCF pôde ser retirado até 24 horas pós-morte. Foram excluídos cadáveres que apresentavam: idade inferior a 18 anos, miopatias, doenças do tecido conjuntivo, história prévia de manipulação da região cervical, intubação oral, nasotraqueal, sonda nasogástrica, nasoentérica, orogástrica, traqueotomia; divertículo de Zenker, cirurgia laríngea ou esofágica prévia e radioterapia da região cervicofacial. 
A idade variou entre 28 e 92 anos (média de 54,63 anos com desviopadrão de 18,34 anos). Vinte indivíduos $(74,1 \%)$ eram do sexo masculino.

Informações relativas ao cadáver como idade, sexo, cor, tabagismo, profissão, causa do óbito, intervalo de tempo desde o óbito e a dissecção do MCF, peso e altura foram obtidas no prontuário do SVOC ou no HCFMUSP (Anexo A).

\subsubsection{Dissecção do músculo cricofaríngeo}

As laringes foram retiradas mediante uma incisão arciforme na região torácica dos cadáveres em um bloco que se estendia desde a língua até o quinto ou sexto anel traqueal, incluindo a glândula tireóide e a musculatura extrínseca. As peças foram dissecadas no Laboratório de Investigação Médica da Disciplina de Otorrinolaringologia da FMUSP (LIM 32), removendo-se as partes moles e isolando-se a transição faringoesofágica (Figura 2A). A porção horizontal do MCF foi dissecada, tendo-se como referência anatômica o ventre oblíquo do músculo cricotireóideo e a disposição horizontal das fibras musculares (Figura 2B). Foi removido um fragmento da porção medial do MCF que incluía também a mucosa (Figuras 2C e 2D). 

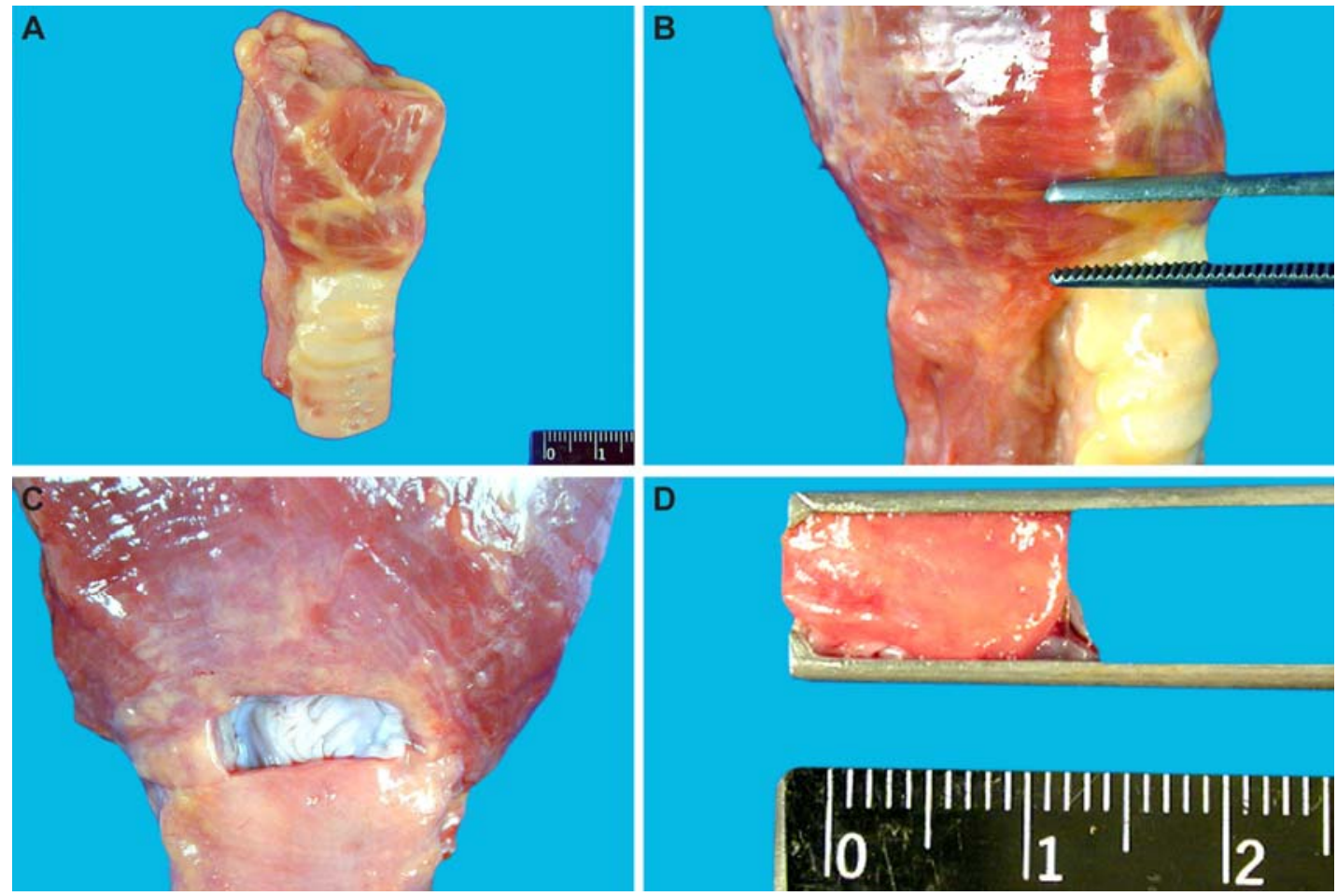

Figura 2 - (A) Bloco laríngeo excisado de cadáver após a remoção das partes moles adjacentes. (B) Identificação da porção horizontal do músculo cricofaríngeo. (C) e (D) Remoção de fragmento da porção medial do MCF e sua mucosa adjacente.

\subsubsection{Preparações histológicas}

Os fragmentos obtidos foram identificados em ordem numérica crescente para que, no momento da análise das lâminas, a idade permanecesse desconhecida pelo pesquisador. Foram então fixados em solução de formalina tamponada a $10 \%$ por 24 horas. Após a fixação, foram desidratados em concentrações alcoólicas progressivas e embebidos em parafina.

Os 27 blocos foram, então, submetidos a cortes histológicos de $5 \mu \mathrm{m}$ de espessura e corados pelos métodos do Setor de Técnica Histológica do Departamento de Patologia da FMUSP sempre pela mesma profissional: 
a) Método Hematoxilina Eosina

Os cortes histológicos foram corados pelo método de rotina da Hematoxilina e Eosina (HE) apenas para identificação de artefatos técnicos e alterações histopatológicas. Os casos que os possuíssem seriam excluídos. Não foram realizadas análises quantitativas dessa coloração.

b) Método Picrossírius: segundo a técnica descrita no Anexo B

c) Método de Resorcina-fucsina de Weigert com oxidação prévia pela oxona: segundo a técnica descrita no Anexo C

Ainda, no Setor de Técnica Histológica, as lâminas foram fixadas com 3-aminopropil-trietoxi-silane (A3648, Sigma-Aldrich, Saint Louis, MO) e posteriormente foram encaminhadas ao Setor de Imunoistoquímica do Departamento de Patologia da FMUSP.

Nesse setor, as reações imunoistoquímicas foram realizadas segundo a técnica descrita no Anexo D, sempre pela mesma profissional. Realizou-se o estudo de quatro marcadores: colágeno I, colágeno III, versican e fibronectina. O preparo das lâminas de todos os casos estudados, para cada marcador, foi sempre realizado em um único dia, para evitar que mudanças de temperatura ambiente influenciassem a reação antígeno-anticorpo.

\subsection{Análise morfométrica}

Para análise quantitativa das macromoléculas estudadas seguiu-se o método descrito por Pickering e Boughner (1991), Melo et al. (2004), Buhler 
et al., (2007) e Araújo et al. (2008). A avaliação quantitativa foi feita por meio da análise digital de imagens utilizando um sistema composto por um microscópio óptico Leica DMR (Leica Microsystems Wetzlar Gmb H, Alemanha) conectado a um computador tipo IBM por uma câmera de vídeo JVC (JVC TK-C1380 Color Video Camera, Victor Company of Japan Limited, Japão) (Figura 3). A lente, a intensidade da luz do microscópio e a altura do condensador foram padronizadas.

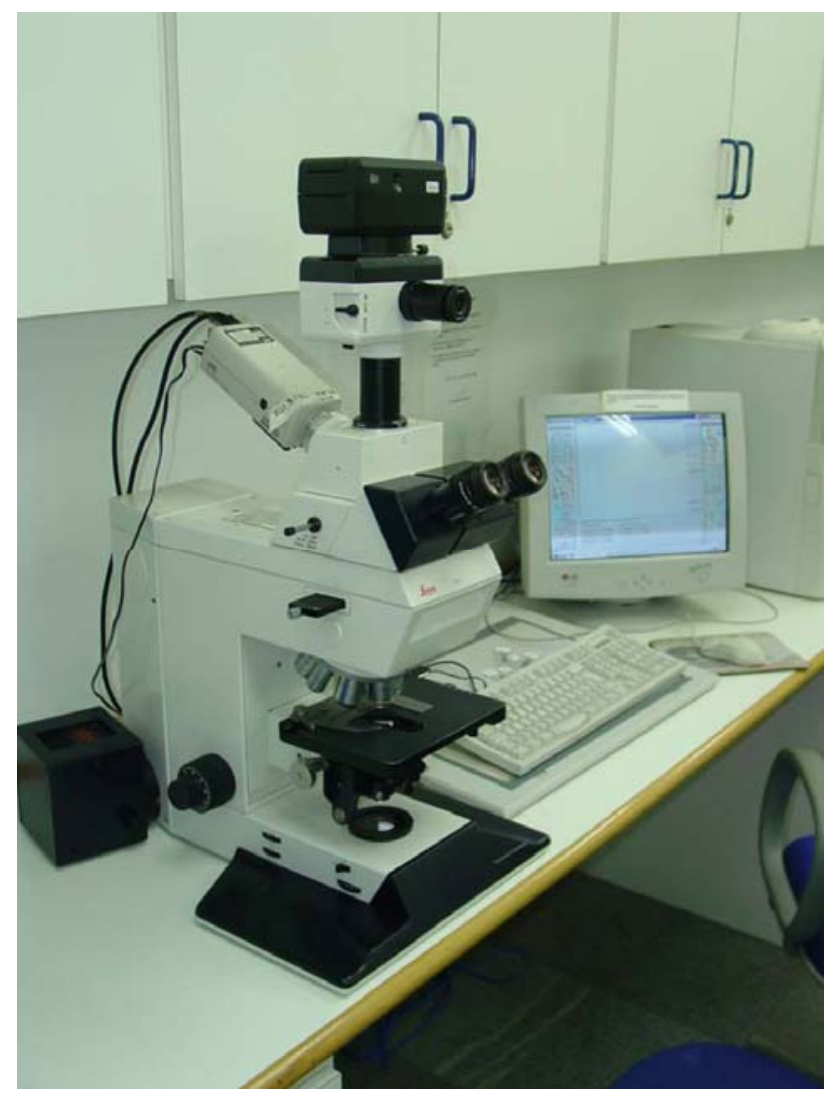

Figura 3 - Sistema de análise de imagens composto por microscópio óptico Leica DMR (Leica Microsystems Wetzlar Gmb H, Alemanha) conectado a um computador tipo IBM por meio de uma câmera de vídeo JVC (JVC TK-C1380 Color Video Camera, Victor Company of Japan Limited, Japão). 
Para cada lâmina de cada coloração, foram capturadas quinze imagens seqüenciais, com aumento de 400X, de modo a conseguir uma visibilização geral do músculo (Figura 4). Tentou-se capturar apenas imagens que contivessem exclusivamente fibras musculares endomisiais, excluindo-se vasos, gordura, mucosa ou mesmo artefatos técnicos.

As imagens capturadas foram analisadas no Museu da Patologia da FMUSP utilizando-se o software Image Pro Plus ${ }^{\circledR}$ versão 4.1 (Media Cybernetics - Silver Spring, MD, EUA) segundo o procedimento seguinte:

1. Padronização de positividade - Fotomicrografias escolhidas ao acaso, $40 \%$ do total, foram utilizadas para estabelecer um padrão de cores para cada elemento estudado, definidos como "positivos" por dois patologistas, portanto ao fim, foram obtidos seis padrões de positividade.

2. Análise - Em cada foto foi delimitada uma área de interesse, compreendendo exclusivamente o endomisio. Foi aplicado o padrão de cores previamente estabelecido obtendo-se a quantificação da expressão do marcador (Figura 5). A seguir a medida total da área de interesse foi obtida. (Figura 6). A expressão dos resultados foi dada em porcentagem (\%) de área proporcional positiva marcada para determinado elemento da MEC em relação à área total de músculo analisado $\left(\mu \mathrm{m}^{2} / \mu \mathrm{m}^{2}\right)$ 


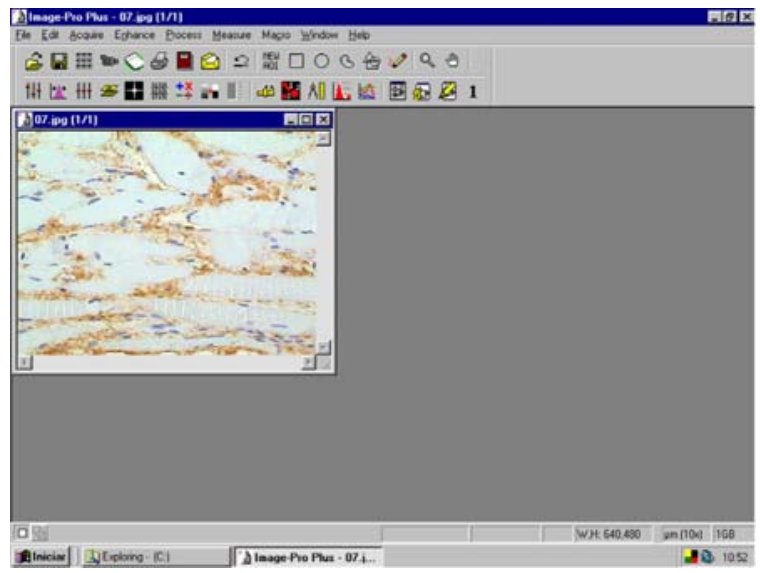

Figura 4 - Software Image Pro Plus ${ }^{\circledR}$ versão 4.1 (Media Cybernetics - Silver Spring, MD, EUA) com imagem capturada de uma lâmina estudada com coloração imunoistoquímica para colágeno tipo I no aumento de $400 X$

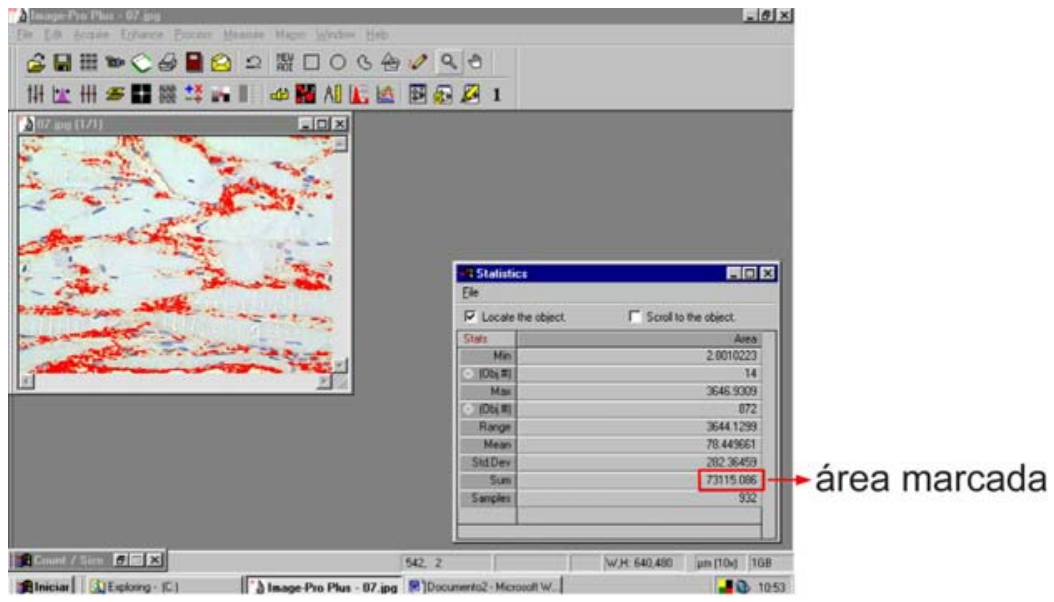

Figura 5 - Aplicação do padrão de cor previamente estabelecido para colágeno tipo I obtendo-se a quantificação da expressão deste marcador (área marcada).

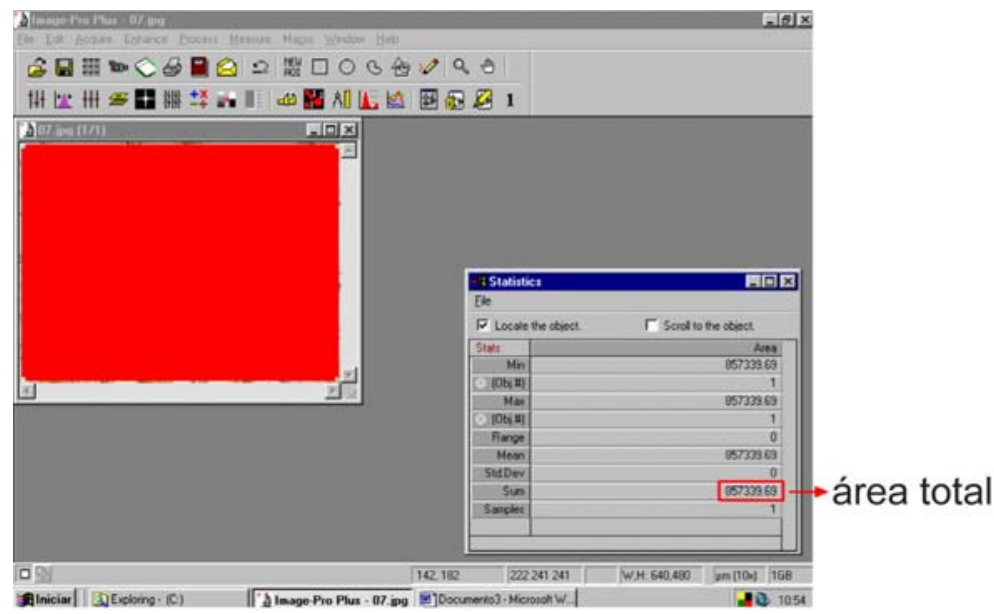

Figura 6 - Medição da área total de interesse (área total). 


\subsection{Análise estatística}

Os dados foram digitados em uma planilha com a aplicação do programa Microsoft Excel e para a análise dos dados foi utilizado o programa estatístico SPSS software 13.0 version (SPSS Inc. ${ }^{\odot}$, Chicago, Illinois, USA).

Todas as variáveis foram analisadas descritivamente. Para as variáveis sexo, cor e tabagismo calculou-se as freqüências absolutas e relativas. Para as variáveis quantitativas a análise foi feita mediante observação da mediana, dos percentis 25 e 75, do intervalo interquartílico, do cálculo de médias e desvios-padrão. A distribuição das variáveis do estudo foi não paramétrica. Para a comparação das medidas nos diferentes sexos, utilizamos o teste de Mann-Whitney. Para correlacionar idade com os elementos da MEC, utilizamos o teste de correlação de Spearman. Consideramos o nível de significância de 5\% $(p<0,05)$ (Rosner, 1986). 
5 RESULTADOS 


\section{RESULTADOS}

\subsection{Características da amostra}

A idade variou entre 28 e 92 anos, com média de 54,6 e desviopadrão de 18,3 . Vinte $(74,1 \%)$ eram do sexo masculino. A seguir, na Tabela 1 e Figura 7, é possível visualizar a distribuição dos indivíduos quanto à faixa etária e raça.

Tabela 1 - Distribuição de freqüências de faixa etária do grupo estudado

\begin{tabular}{l|c|c}
\hline \hline Idade (anos) & $\mathbf{n}$ & $\%$ \\
\hline$<\mathbf{4 0}$ & 6 & 22,2 \\
$\mathbf{4 0 - 5 0}$ & 5 & 18,5 \\
$\mathbf{5 0 - 6 0}$ & 5 & 18,5 \\
$\mathbf{6 0 - 7 0}$ & 5 & 18,5 \\
$\geq 70$ & 6 & 22,2 \\
\hline Total & 27 & 100,0 \\
\hline \hline
\end{tabular}

$\mathrm{n}=$ número de casos; $\%$ = porcentagem

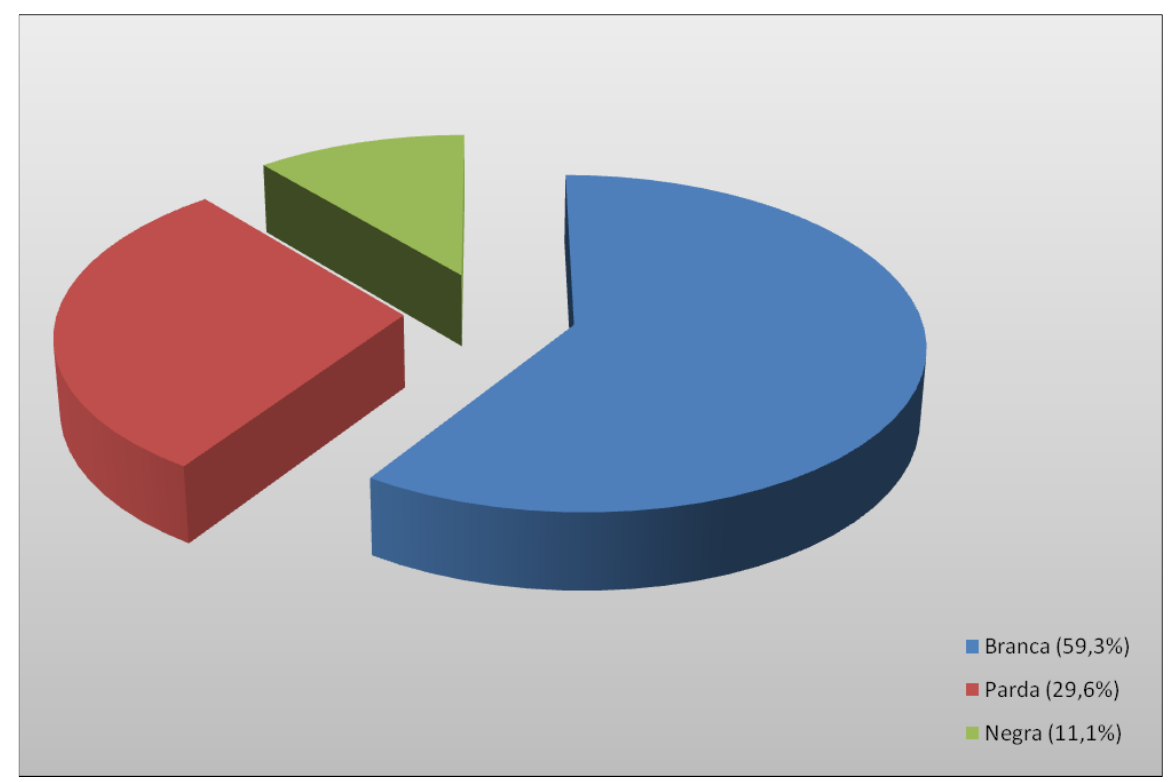

Figura 7 - Distribuição dos casos estudados quanto raça 
Onze $(40,7 \%)$ indivíduos eram tabagistas ou ex-tabagistas, 13 $(48,1 \%)$ não tabagistas e a respeito de $3(11,1 \%)$ não dispúnhamos dessa informação.

A média do peso foi de $69,2 \pm 12,1 \mathrm{~kg}$. A média da altura foi de $171,9 \pm 7,6 \mathrm{~cm}$. O tempo desde o óbito até a dissecção e fixação do material variou de cinco a 23 horas, com média de 16,2×3,7h (média 16,2h e desviopadrão 3,7h).

\subsection{Distribuição das fibras do sistema colagênico e elástico por métodos histoquímicos}

Nos cortes histológicos corados pelo método de rotina da HE foi possível visualizar o MCF e sua mucosa adjacente (Figura 8). Nos indivíduos idosos, é possível verificar, à macroscopia, uma atrofia das fibras musculares esqueléticas (Figuras 9A e 9B). 


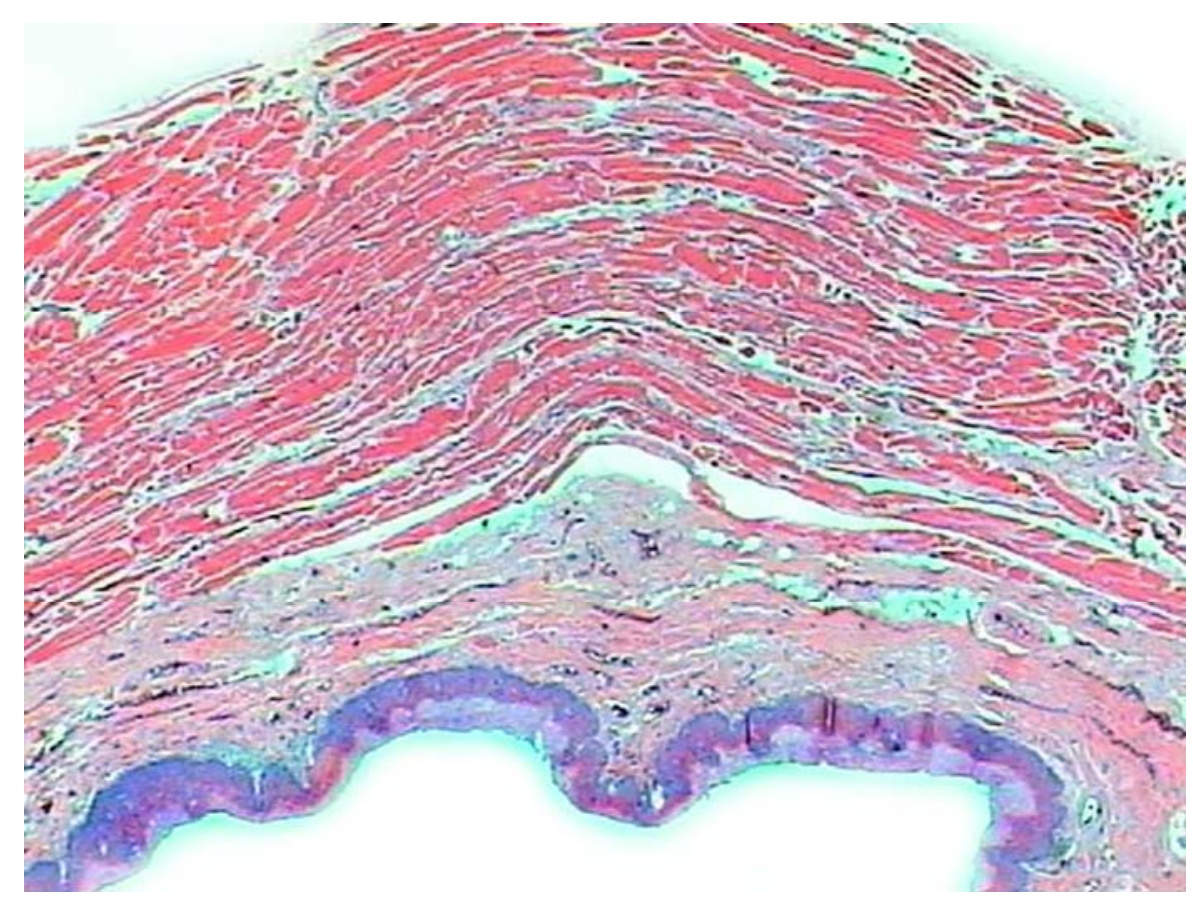

Figura 8 - Corte histológico corado com método Hematoxilina e Eosina visualizado sob luz convencional, que mostra o músculo cricofaríngeo e sua mucosa adjacente (aumento de 250X). Observa-se a ausência de artefatos técnicos e inflamação local.

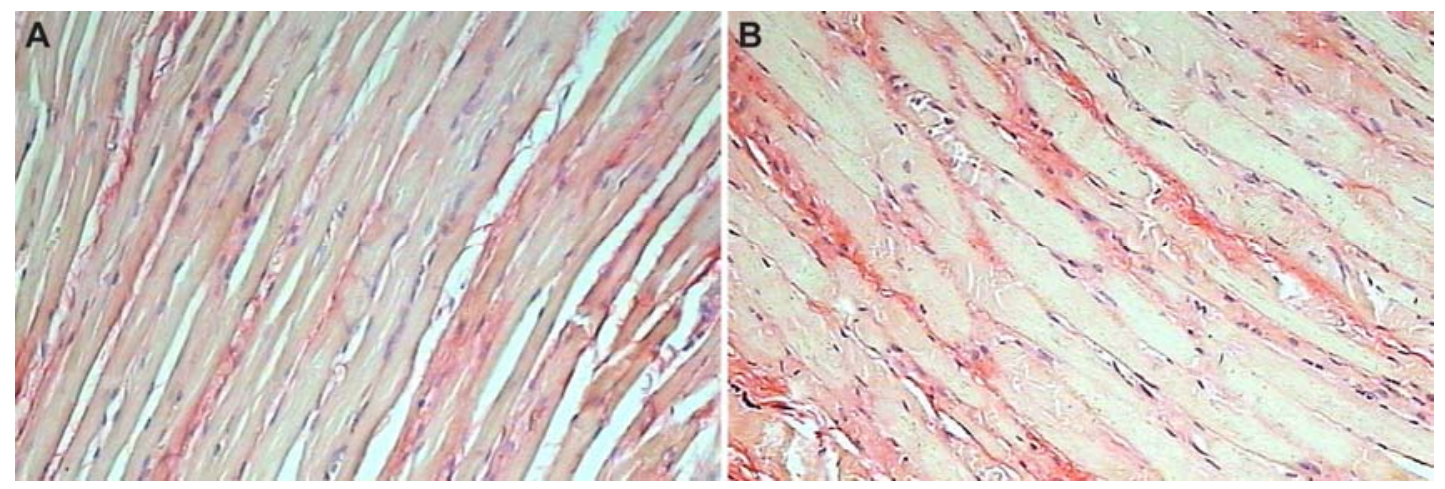

Figura 9 - Cortes histológicos corados com método Picrossírius visualizados sob luz convencional, mostrando a diferença macroscópica na espessura das fibras musculares em indivíduo idoso (A) e em jovem (B) (aumento de 400x). Nota-se as fibras colágenas (vermelho) que revestem as células musculares individualmente. 
Os cortes histológicos do MCF corados com Picrossíruis e observados com luz convencional permitiram claramente evidenciar as fibras de colágeno endomisial (Figuras 9A, 9B e 10). Os cortes teciduais corados pelo método resorcina-fuccina de Weigert após oxidação revelaram uma peculiar distribuição das fibras do sistema elástico no endomísio do MCF. Observa-se que fibras elásticas envolvem células musculares individual e longitudinalmente, ligam-se umas às outras por fibras delgadas em disposição transversal em relação à célula muscular (Figura 11A) e espessam-se na extremidade da célula muscular (Figura 11B), como se as fibras musculares estivessem inseridas em uma fina rede de fibras elásticas.

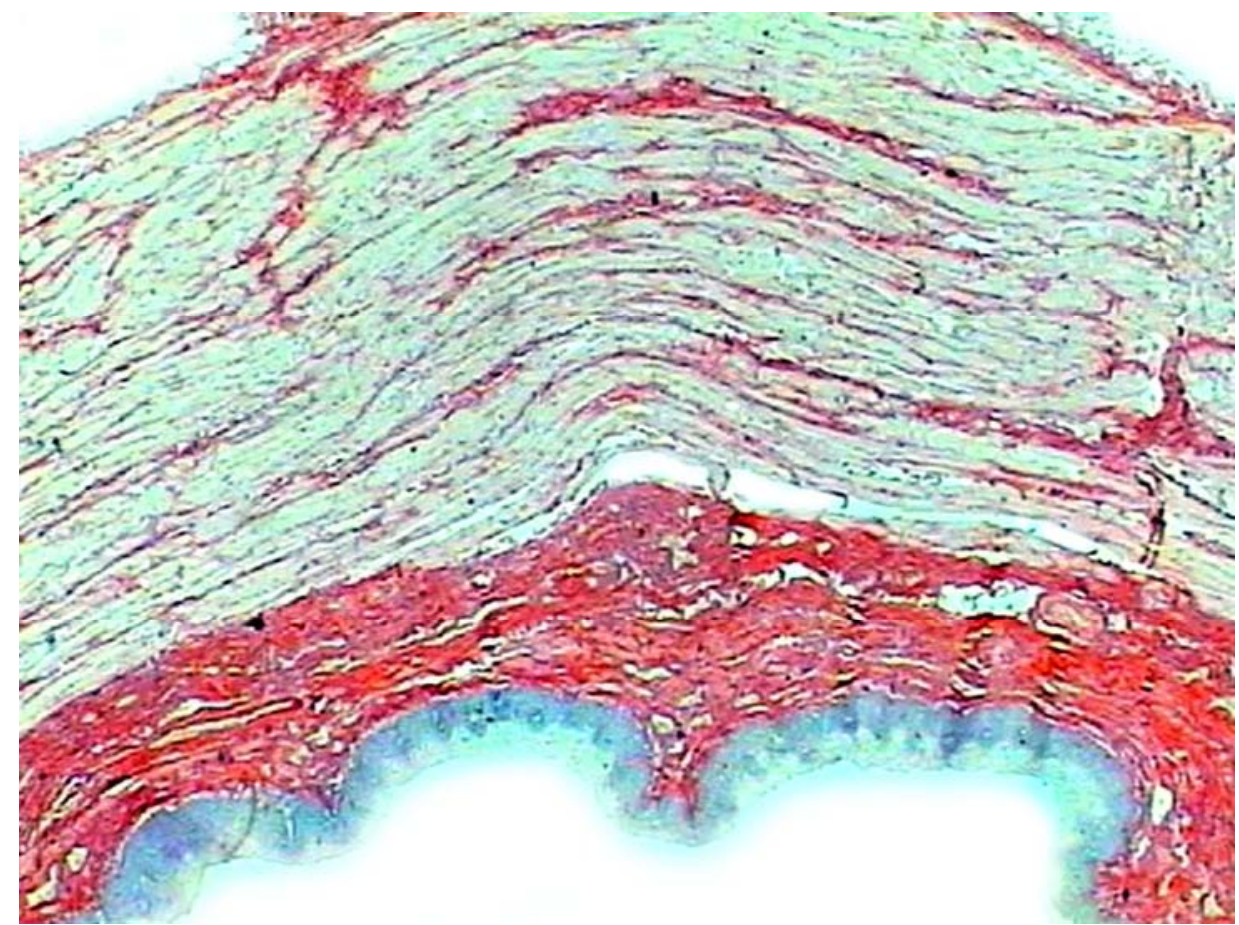

Figura 10 - Corte histológico corado com método Picrossírius visualizado sob luz convencional que mostra a distribuição do colágeno total (vermelho escuro) no endomísio do músculo cricofaríngeo e sua mucosa adjacente (aumento de 250X). 

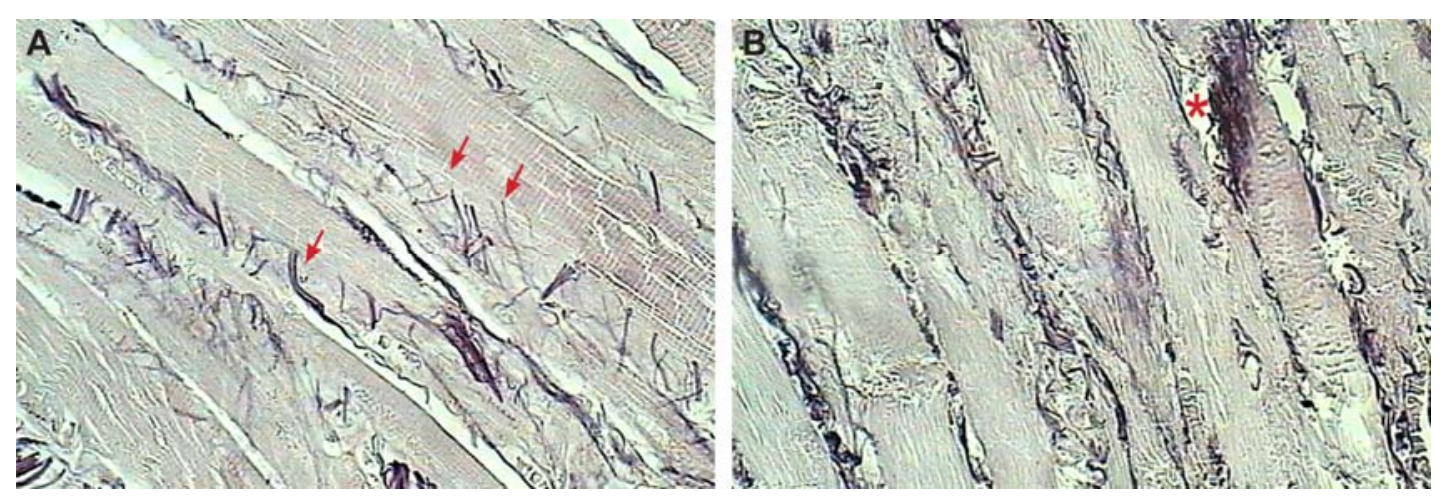

Figura 11 - Corte histológico corado pelo método resorcina-fuccina de Weigert após oxidação que mostra a rede de fibras elásticas no músculo cricofaríngeo (aumento de 400x). (A) Observa-se fibras elásticas delgadas envolvendo células musculares, que se ligam umas às outras por delgadas fibras em disposição transversal em relação à célula muscular (seta vermelha). (B) Fibras elásticas que se espessam na extremidade da célula muscular (asterisco vermelho).

A área porcentual do colágeno total e das fibras elásticas no endomísio do MCF e sua comparação entre os sexos encontram-se disponíveis nas Tabelas 2 e 3.

Tabela 2 - Área porcentual do colágeno total e das fibras elásticas no músculo cricofaríngeo pelos métodos Picrossírius e Resorcinafuccina oxidada de Weigert

\begin{tabular}{l|c|c|c|c}
\hline \hline Elemento estudado & Mediana & P25 & P75 & IIQ \\
\hline Colágeno total & 4,8 & 2,6 & 7,7 & 5,1 \\
Fibras elásticas & 2,6 & 1,5 & 3,5 & 1,9 \\
\hline \hline
\end{tabular}

P25 = percentil 25; P75 = percentil 75; IIQ = intervalo interquartílico 
Tabela 3 - Teste de Mann-Whitney para a comparação da área porcentual de colágeno total e das fibras elásticas entre os sexos

\begin{tabular}{c|c|c}
\hline \hline & Colágeno Total & Fibras elásticas \\
\hline Mediana & 5,3 & 2,6 \\
Masculino & 4,7 & 3,2 \\
Feminino & 1,1 & 1,0 \\
Valor mínimo & 1,7 & 1,5 \\
Masculino & & \\
Feminino & 16,9 & 8,2 \\
Valor máximo & 8,7 & 6,3 \\
Masculino & & 0,65 \\
\hline Feminino & 0,40 &
\end{tabular}

$\mathrm{p}=$ nível de significância; $\mathrm{p}<0,05 ;{ }^{*}=$ nível descritivo de probabilidade do teste não paramétrico de Mann-Whitney.

\subsection{Distribuição dos elementos da matriz extracelular por métodos imunoistoquímicos}

Os cortes histológicos do MCF corados por imunoistoquímica para colágeno tipo I e tipo III e observados sob luz convencional permitiram evidenciar a presença desses elementos distribuídos de maneira homogênea em todo o endomísio (Figuras 12A e 12B). 

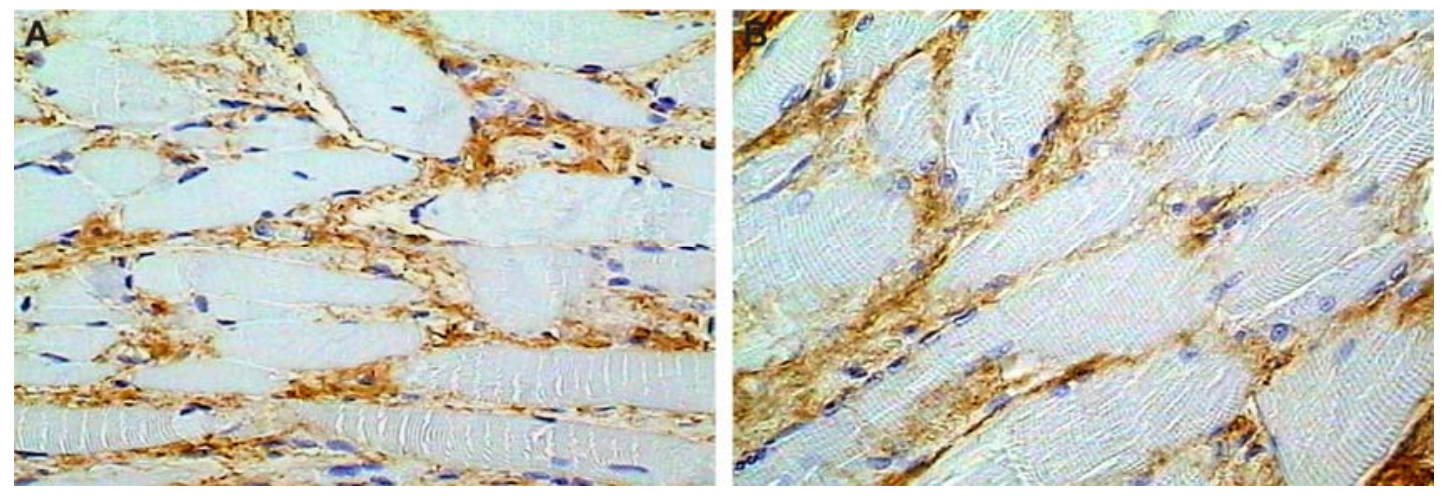

Figura 12 - Corte histológico corado pela técnica de imunoistoquímica que mostra a distribuição do colágeno tipo I (A) e colágeno tipo III (B) em coloração em marrom (aumento de 400X)

A fibronectina e o versican foram os elementos mais escassos dentre os analisados. Anticorpos para fibronectina coraram o endomísio, mas de forma menos densa que para os colágenos, num padrão fibrilar (Figura 13A). Em alguns casos pode-se evidenciar fibronectina no interior da célula muscular (Figura 13B).
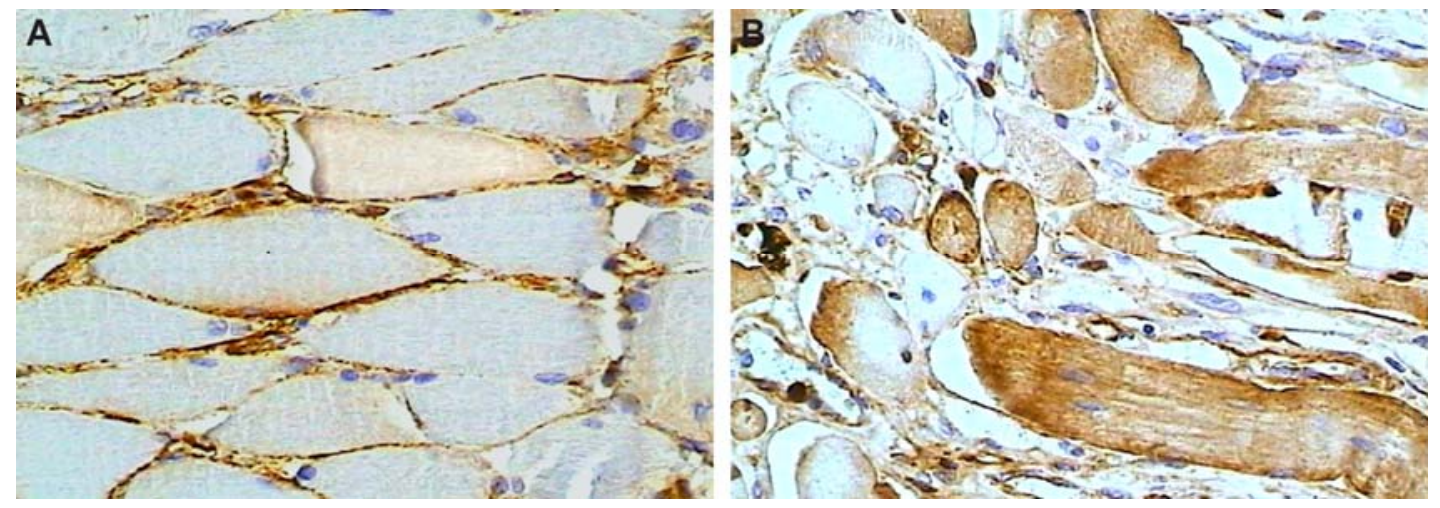

Figura 13 - Corte histológico corado pela técnica de imunoistoquímica para a fibronectina (em coloração em marrom). (A) mostra a distribuição endomisial, e (B) a distribuição sarcolemal de alguns casos (aumento de 400X). 
Ao contrário da fibronectina nenhum versican foi observado dentro das fibras musculares (Figura 14A). Alguns casos mostraram abundante imunopositividade para versican, enquanto em outros casos o versican achava-se quase ausente (Figura 14B).
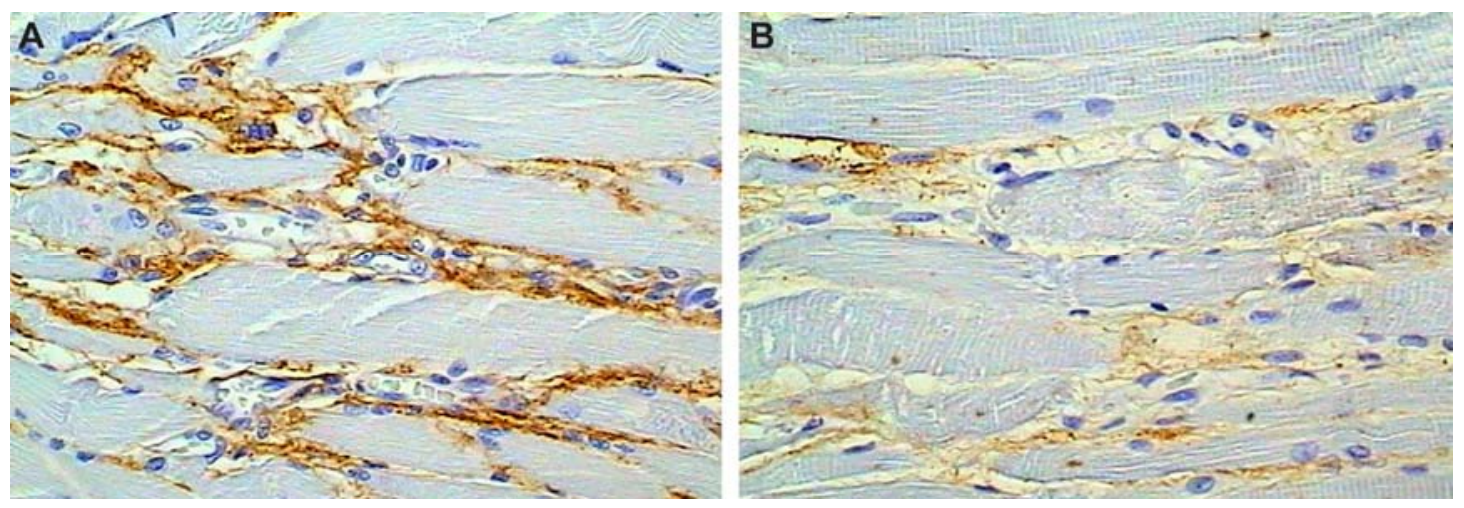

Figura 14 - Corte histológico corado pela técnica de imunoistoquímica para a versican (em coloração em marrom). (A) mostra a distribuição endomisial e (B) a escassa distribuição em alguns casos (aumento de 400x).

A área porcentual do colágeno tipo I, tipo III, fibronectina e versican encontra-se na Tabela 4. A comparação entre esses elementos nos sexos encontra-se na Tabela 5.

Tabela 4 - Área porcentual dos elementos da matriz extracelular por imunoistoquímica

\begin{tabular}{l|c|c|c|c}
\hline \hline Elemento estudado & Mediana & P25 & P75 & IIQ \\
\hline Colágeno tipo I & 7,6 & 5,6 & 8,7 & 3,0 \\
Colágeno tipo III & 6,2 & 4,7 & 9,8 & 5,0 \\
Fibronectina & 2,3 & 1,3 & 4,4 & 3,1 \\
Versican & 2,8 & 1,4 & 4,8 & 3,4 \\
\hline \hline
\end{tabular}

$\overline{\mathrm{P} 25}=$ percentil 25; P75 = percentil 75; IIQ = intervalo interquartílico 
Tabela 5 - Teste de Mann-Whitney para a comparação da área percentual dos elementos da matriz extracelular por imunoistoquímica entre os sexos

\begin{tabular}{l|c|c|c|c}
\hline \hline & $\begin{array}{c}\text { Colágeno } \\
\text { tipo I }\end{array}$ & $\begin{array}{c}\text { Colágeno } \\
\text { tipo III }\end{array}$ & Fibronectina & Versican \\
\hline Mediana & & & & \\
$\quad$ Masculino & 8,3 & 6,5 & 2,5 & 3,0 \\
$\quad \begin{array}{l}\text { Feminino } \\
\text { Valor mínimo }\end{array}$ & 5,9 & 6,1 & 2,4 & 2,6 \\
$\quad$ Masculino & 4,2 & 2,0 & 0,05 & 0,5 \\
$\quad$ Feminino & 1,8 & 3,1 & 0,05 & 1,0 \\
Valor máximo & & & & \\
$\quad$ Masculino & 9,3 & 19,9 & 7,8 & 11,1 \\
$\quad$ Feminino & 10,8 & 16,7 & 18,7 & 15,1 \\
\hline Significância (p*) & 0,22 & 1,0 & 0,86 & 0,86 \\
\hline
\end{tabular}

p = nível de significância $<0,05 ;{ }^{*}=$ nível descritivo de probabilidade do teste não paramétrico de Mann-Whitney.

\subsection{Associação entre as medidas e a idade}

Para correlacionar idade com os elementos da MEC estudados, utilizamos o teste de correlação de Spearman (Tabela 6).

Tabela 6 - Análise de correlação de Spearman entre a idade e as áreas porcentuais dos elementos estudados

\begin{tabular}{lc|c}
\hline \hline Elemento estudado & Correlação & Significância (p) \\
\hline Colágeno total & 0,276 & 0,163 \\
Fibras elásticas & 0,253 & 0,201 \\
Colágeno tipo I & 0,166 & 0,407 \\
Colágeno tipo III & $-0,001$ & 0,994 \\
Fibronectina & 0,038 & 0,847 \\
Versican & 0,275 & 0,217 \\
\hline \hline
\end{tabular}

p = nível de significância $<0,05$ 
6 DISCUSSÃO 


\section{DISCUSSÃO}

O MCF tem grande importância fisiológica no processo da deglutição, por causa da rápida capacidade de abertura ou distensão durante diversos estados fisiológicos. Esse comportamento elástico depende não apenas dos elementos contráteis musculares, mas também do tecido conjuntivo intramuscular (Asoh, Goyal, 1978; Järvinen, 2002). Apesar disso, informações sobre a composição da matriz extracelular do MCF permanecem bem pouco conhecidas.

A literatura tradicionalmente afirma que o MCF apresenta características histológicas peculiares e distintas dos outros músculos esqueléticos no que diz respeito a sua organização morfológica (Singh, Hamdy, 2005), mas não especifica detalhadamente o conteúdo de colágeno total, de fibras elásticas ou das outras macromoléculas que formam a matriz extracelular. Até onde pudemos pesquisar, esse é o primeiro estudo que aborda esta questão.

O principal objetivo do nosso estudo foi, então, obter informações a respeito de elementos específicos da matriz extracelular no endomísio do MCF, mediante a quantificação morfométrica, em diferentes idades, e verificar possíveis alterações nesses componentes em relação à idade e ao sexo.

A maioria dos estudos que avalia a função da TFE e as alterações decorrentes da idade ou de condições patológicas utiliza técnicas de 
manometria, eletromiografia, videofluoroscopia ou uma combinação delas (Robbins et al. 1992; Cook, 1993; Dejaeger et al., 1994; Shaw et al., 1995). Todavia, os poucos estudos histológicos publicados sobre o MCF têm ajudado muito na compreensão da função e disfunção dessa região, e com isso, permitido o aperfeiçoamento e desenvolvimento de novas formas de terapia cirúrgica ou fonoaudiológica (Cruse, 1979; Hanna, Hhenderson, 1980; Bonigton et al., 1988; Brownlow et al., 1989; Kristmundsdottir et al., 1990; Laurikainen et al., 1992; Singh, Hamdy, 2005).

\subsection{Da seleção da amostra}

Um dos problemas que advém da utilização de tecidos humanos obtidos de cadáveres para estudos histológicos é o tempo decorrido entre o óbito e a fixação do material, uma vez que ocorrem modificações teciduais após a morte. Por isso, estudos onde o tecido muscular foi o principal foco de análise utilizam um tempo menor entre o óbito e a fixação do material para minimizar as alterações da histo-arquitetura tecidual (Ronsenfirld et al., 1982). Outro problema dos estudos histológicos é o conhecimento da história patológica pregressa dos indivíduos avaliados e da presença de doenças que possam implicar em alterações teciduais. No caso de estudos histológicos no MCF é importante, ainda, excluir indivíduos que tenham sido submetidos à intubação endotraqueal, à passagem de sondas nasogástrica, orogástrica ou nasoentérica que poderiam induzir a um processo inflamatório 
local. (Kelly, 1996).

Nesse trabalho, utilizamos critérios de inclusão e exclusão rigorosos no intuito de reduzir os vieses no estudo. Utilizamos tecidos removidos e fixados com até 23 horas do óbito. Durante este período de tempo, a atividade enzimática mantém-se preservada e os artefatos pós-morte são ausentes ou mínimos (França, 2001). Além disso, todos os indivíduos tiveram história patológica pregressa, documentada por inspeção do prontuário médico no SVOC, no HC ou em outros hospitais e foram excluídos indivíduos que sabidamente apresentassem queixa de disfagia, ou miopatias ou quaisquer outras doenças que pudessem alterar as características histológicas do MCF.

Nenhum indivíduo incluído apresentava intubação endotraqueal e presença de sonda nasogástrica, orogástrica ou nasoentérica, medidas que poderiam induzir a um processo inflamatório no MCF e por conseqüência, alterar a proporção dos constituintes da matriz extracelular. Fomos surpreendidos, no entanto, por uma dificuldade em incluir casos que preenchessem esses critérios no limitado intervalo de tempo que dispúnhamos. Portanto, o grupo estudado constituiu-se de uma amostra não aleatória do tipo "por conveniência". Amostras como essas, são selecionadas por um julgamento de valor, no caso os critérios de inclusão e exclusão, e não por questões de randomicidade estatística.

Tivemos um cuidado adicional em nosso estudo. Identificamos todos os espécimes estudados em ordem numérica crescente, para que variáveis como a idade e o sexo dos indivíduos permanecessem desconhecidos pelo 
pesquisador. Desta forma, procuramos limitar a introdução de vieses de observação, pelo cegamento do avaliador quanto a estas variáveis.

Um ponto importante na seleção dos nossos casos foi a tentativa de obter uma amostra representativa da população brasileira. Incluímos indivíduos adultos cujas idades variaram de 28 a 92 anos, e que apresentavam uma distribuição racial parecida com a encontrada no Brasil. No nosso estudo (Figuras 2 e 7) tivemos 59\% de brancos, $29 \%$ de pardos e 11\% de negros, enquanto no Brasil, segundo dados do IBGE (2002) temos $53 \%$ de brancos, $39 \%$ de pardos e $6 \%$ de negros.

\subsection{Da quantificação dos elementos da matriz extracelular}

O tecido conectivo intramuscular encontra-se em íntimo contato com a fibra muscular, desempenha papel importante no processo de contração e está mais sujeito às alterações decorrentes do uso e do desuso (Järvinen, 2002). Além disso, segundo Alnaqeeb (1984) as alterações quantitativas decorrentes da idade no conteúdo de colágeno são mais evidentes no endomísio. Por essas razões, optamos por estudar o tecido conjuntivo endomisial.

Como nossos resultados seguem uma distribuição assimétrica ou não paramétrica, optamos por utilizar a mediana como medida de tendência central, percentil 25, percentil 75 e o intervalo interquartílico como medidas de dispersão da variáveis quantitativas estudadas, ou seja, a área porcentual 
do colágeno total, dos tipos I e III, das fibras elásticas, da fibronectina e do versican no endomísio do MCF (Tabelas 2 e 4).

O colágeno tipo I e tipo III são os principais e mais abundantes colágenos no músculo esquelético e estão presentes nos três níveis de organização do tecido conjuntivo intramuscular. $O$ endomísio, tecido conjuntivo que circunda individualmente cada fibra muscular, é rico em colágeno tipo I, III, IV e V. Estudos de Kovanen (1989) afirmam que o conteúdo de colágeno no músculo esquelético gira em torno de um a $9 \%$ de sua massa.

Nossos resultados mostram que o colágeno é o elemento mais abundante dentre os estudados. Organiza-se em delgadas fibras que revestem as células musculares individualmente e em pequenas pontes que ligam as células entre si e com a matriz extracelular (Figuras 9 A, 9B e 10). Acreditamos, em concordância com Goyal et al. (1993), que a presença dessa trama de suporte colagenosa contribua para que o MCF se mantenha tonicamente contraído.

Nossos achados, todavia, diferem de estudos previamente publicados por Bonington et al. (1988), Kristmundottir (1990) e Laurikainen (1992) que utilizam técnicas histoquímicas e que vêem uma variação de 10 a 40\% no conteúdo do tecido conectivo no MCF. Entendemos que isso pode ser decorrente das razões seguintes:

a) Quantificação de outros tecidos e de outros compartimentos musculares: nossos resultados refletem o conteúdo de colágeno presente apenas no endomísio do MCF. Não avaliamos 
colágeno perimisial, nem componentes não musculares, como tecido gorduroso, nervos e vasos.

b) Método de quantificação: utilizamos a histomorfometria mediante um sistema de análise e processamento de imagens (Software Image Pro-Plus), que nos confere análise precisa do elemento a ser estudado, eliminando assim o viés da avaliação qualitativa individual quando se utiliza escores de graduação ou ocular integradora (Pickering, Boughner, 1991; Melo et al., 2004; Buhler et al., 2008; Araújo et al., 2008).

c) Metodologia estatística: é ainda possível que tamanha diferença seja decorrente de diferentes amostragens. Alguns estudos utilizam uma amostra muito pequena e não homogênea quanto à idade dos indivíduos e estão sujeitos a fortes críticas estatísticas. Além de termos utilizado critérios de inclusão rigorosos, o que nos levou a uma amostragem homogênea, nosso estudo inclui uma das maiores casuísticas de MCF humano (Cruse, 1979; Hanna, Henderson, 1980; Bonigton et al., 1988; Brownlow et al.,1989; Kristmundsdottir et al., 1990; Laurikainen et al., 1992).

O conteúdo de fibras elásticas e sua disposição nos tecidos variam de acordo com o tipo de tecido e com a função tecidual (Rodrigues, 1994; Kielty, 2000). Pode compreender uma pequena, mas importante fração da massa seca do tecido, variando de 2 a $4 \%$ na pele, até mais que 50\%, nas grandes artérias (Rosembloom, 1993).

No presente trabalho demonstramos a presença de fibras elásticas 
oxitalânicas, elaunínicas e elásticas maduras, à microscopia de luz, como componentes do tecido conjuntivo do MCF. A coexistência dos três tipos de fibras elásticas parece expressar uma elastogênese normal (Pecora et al., 2001). O único estudo previamente publicado sobre fibras elásticas no MCF limita-se a afirmar que o mesmo apresenta numerosas fibras elásticas (Kristmundottir, 1990) sem, contudo, quantificá-las ou descrevê-las.

A organização do sistema de fibras elásticas contribui para a arquitetura tecidual e promove o recolhimento passivo do tecido à sua unidade original quando este é submetido a estresse mecânico. Nos nossos casos, encontramos uma disposição interessante do sistema de fibras elásticas, na qual elas envolvem células musculares individual e longitudinalmente, espessam-se na extremidade da célula muscular e ligamse umas às outras por delgadas fibras em disposição transversal em relação à célula muscular, como se as fibras musculares estivessem inseridas em uma fina rede de fibras elásticas (Figuras 11A e 11B).

Comparado com outros músculos da faringe, o MCF é extremamente elástico. Dantas (2009) estuda a MEC (matriz extracelular) do músculo constrictor superior da faringe em indivíduos com Síndrome da Apnéia Obstrutiva do Sono por meio de metodologia semelhante à nossa e encontra metade do conteúdo de colágeno tipo III e um terço de fibras elásticas. Acreditamos que essas características influenciam o comportamento MCF e podem responder por sua capacidade de voltar rapidamente à posição tônica após as distensões rápidas durante as deglutições. (Sivarao, Goyal, 2000) 
A fibronectina é uma glicoproteína adesiva e sua capacidade de ligação parece especialmente importante na construção de conexões teciduais normais, nas fases iniciais da cicatrização e na remodelação de alterações teciduais (Hynes, 1982; Kannus et al., 1998). Em nossos resultados podemos observar que a imunopositividade para fibronectina segue um padrão de distribuição fibrilar classicamente descrito no músculo esquelético (Foidart et al., 1981), presente no endomísio do MCF, onde ligações firmes entre as fibras musculares e o colágeno são necessárias. Em alguns de nossos casos, a fibronectina foi encontrada dentro das células musculares. Expressão de fibronectina sarcoplasmática também foi encontrada por Gulati et al. (1982) em músculos regenerados. Após o autotransplante, esses autores observam uma diminuição da fibronectina endomisial e um aumento da fibronectina sarcoplasmática em fibras isquêmicas e degeneradas.

O versican, por sua vez, é um proteoglicano com característica capacidade de ligação ao ácido hialurônico. Agregados de versican e ácido hialurônico são capazes de modelar processos celulares envolvidos na cicatrização e invasão tumoral (Sorrel, 1999). Em nossos casos, a expressão do versican pôde ser identificada no endomisio do MCF como descrito por Bode-Lesniewska et. al. (1996).

Acredita-se que o MCF apresente características histológicas distintas dos outros músculos esqueléticos. De fato, está exposto a vários fatores agressores como refluxo gatroesofágico crônico (Hanna, Henderson, 1980), estresse físico e químico por exposição a alimentos quentes e bebidas 
alcoólicas (Laurikainen et al.,1992), desgaste natural pelo ato de deglutir ao longo da vida (Cruse, 1979). Essas agressões: justificam a presença de alterações de fibras musculares e do infiltrado inflamatório crônico inespecífico, anteriormente descritas por Cruse (1979), reforçam a necessidade do versican e da fibronectina, como mediadores inflamatórios, em manter a homeostase tecidual, e podem, ainda, justificar as diferenças interindividuais.

\subsection{Das alterações correlacionadas à idade e ao sexo}

Para avaliar a associação entre as medidas estudadas e o sexo foi utilizado o teste de Mann-Whitney que compara as médias dos elementos de grupos que apresentam uma distribuição não paramétrica. Não encontramos diferença estatisticamente significativa (Tabelas 3 e 5 ). Nos estudos manométricos de McKee et al. (1998) não foi observada diferença entre os sexos na onda de pressão faríngea durante a deglutição. Nossos resultados estão de acordo com os estudos histólogicos de Kristmundottir (1990) que não observa diferenças entre ambos os sexos com relação à quantidade de tecido conjuntivo em seu estudo.

Para analisarmos possíveis alterações correlacionadas com 0 envelhecimento, optamos pela análise por meio da correlação de Spearman. Este tipo de teste estatístico é utilizado para uma distribuição não paramétrica e não traduz a relação de causa e efeito, porém nos mostra se 
existe algum grau de associação entre uma variável independente (idade) e as diversas variáveis dependentes testadas, ou seja, o colágeno total, seus subtipos I e III, as fibras elásticas, a fibronectina e o versican.

Mediante o uso da correlação de Spearman observamos uma correlação fraca entre idade e os elementos da matriz estudados (Tabela 6). Dantas (2009) encontra uma correlação positiva significante entre a idade e o colágeno tipo I e uma correlação negativa entre a idade e o colágeno tipo III no músculo constrictor superior da faringe. De acordo com nossos resultados podemos corroborar com o trabalho de Kristmundottir (1990) que não vê alteração entre o colágeno do MCF e idade, e discordar do trabalho de Laurikainen (1992). Isso nos abre um leque de possibilidades:

a) Que o MCF não sofre as mesmas alterações com a idade que outros músculos esqueléticos.

Sabe-se que com o envelhecimento do tecido muscular esquelético existe caracteristicamente a perda da massa e das fibras musculares tipo II (Lexel et al., 1988; Kovanen, 1989, Chow et al., 2005; Volpi et al., 2004), mas isso parece não ocorrer no MCF. Segundo Brownlow et al.,(1989) o MCF não sofre perda de fibras tipo II, mas em nossos casos (Figura 9 A) é possível verificar uma evidente atrofia das fibras musculares à macroscopia.

Por manter-se sempre em atividade (Kahrilas, 1994), seja tonicamente contraído ou abrindo-se durante as deglutições, eructações e durante o vômito, o MCF não sofreria o efeito da imobilização e do desuso, que habitualmente ocorre em músculos esqueléticos dos membros em 
idosos, e que pode resultar em alterações do conteúdo dos elementos da matriz extracelular, principalmente o colágeno (Mohan, Radha, 1975; Alnaqeeb, 1984; Carvalho Filho et al., 1996). Imamura (1996) demonstra que o nível de atividade física influencia o fenômeno do envelhecimento do colágeno dos músculos estriados de ratos. A atividade física pode retardar e mesmo reverter os efeitos deletérios relacionados ao envelhecimento.

b) Que as alterações qualitativas dos elementos da matriz extracelular se sobreponham às alterações quantitativas.

A análise quantitativa isolada dos elementos da matriz extracelular não permite concluir a respeito da influência desses elementos nas propriedades mecânicas e viscoelásticas do tecido. A integração do sistema de fibras elásticas e colágenas, por exemplo, é importante para a manutenção da resistência tecidual normal. Alterando-se a composição do colágeno, da elastina ou alterando-se seu arranjo arquitetural, certamente a complacência tecidual será comprometida.

A complacência tecidual é influenciada, em parte, pela quantidade de ligações cruzadas entre as cadeias de aminoácidos do colágeno. Com a idade, ocorrre um aumento da maturação dessas ligações cruzadas, o que levaria a uma maior agregação das fibrilas e tornaria o colágeno mais resistente à tensão (Rodrigues et al., 1996). Nos idosos, as fibras elásticas são maiores e mais largas (Rodrigues, Rodrigues Júnior, 2000), provavelmente em virtude da queda da reciclagem da elastina, do aumento de ligações cruzadas e da deposição de ácidos graxos e sais de cálcio entre 
suas moléculas. Carvalho Filho et al. (1996) e Rodrigues Júnior et al. (2000) acreditam que alterações na arquitetura das fibras elásticas decorrentes do processo do envelhecimento levariam a diminuição da elasticidade original dos tecidos. Carrino et al. (2000) verificam alterações estruturais nas moléculas de versican e decorina na pele humana em função da idade e postulam que essas diferenças podem justificar, pelo menos em parte, mudanças na hidratação e resistência da pele de idosos. Essas alterações poderiam justificar, de certa forma, a menor distensibilidade do MCF em idosos.

c) Que mecanismos outros, além do envelhecimento da matriz extracelular, estejam implicados no declínio da função do MCF

A idade afeta negativamente vários componentes do sistema responsável pela deglutição, desde o controle central até os órgãos musculares efetores (McComas et al., 1973). Essas alterações são freqüentemente compensadas sob condições normais e não alcançam nível sintomático, até que eventos neurológicos, problemas sistêmicos ou causas externas resultem em disfagia. (Staff, Shaker, 2001)

Com o envelhecimento, existe comprometimento de mecanismos responsáveis pela abertura da TFE: a) diminuição do relaxamento do MCF pela diminuição do aferência sensorial; e, b) diminuição da amplitude de contração da musculatura suprahioidea (Kern et al., 1999). Anormalidades em um desses mecanismos causam diminuição da abertura do MCF durante a deglutição. 
Apesar de não termos encontrado correlação positiva entre idade, sexo e os elementos estudados, não significa que podemos descartar a possibilidade de alterações visto que nossa amostragem não tem poder para isso.

É interessante perceber que não observamos variação em nenhum dos componentes estudados, como se a matriz extracelular sempre funcionasse no sentido de manter uma homeostase entre seus componentes. Segundo Boyer et al. (1991) a expressão dos genes que codificam a matriz extracelular sofre regulação dependente da idade. No caso do MCF essa regulação parece semelhante para as diferentes macromoléculas da matriz.

É difícil determinar as contribuições individuais dos componentes biológicos da matriz extracelular nas propriedades mecânicas do músculo. Mas é importante entender como os constituintes químicos (colágeno, fibras elásticas, glicosaminoglicanos, glicoproteína e água) fornecem seus atributos aos tecidos. No MCF, a presença desses elementos e a quantidade de fibras colágenas e elásticas observada nesse estudo é compatível com a característica de esfincter do músculo (Laurikainen et al., 1992).

De forma isolada, dados referentes à matriz extracelular podem ter um pequeno impacto funcional em indivíduos normais, mas podem ser importantes para a correta avaliação de pacientes com disfagia orofaringea.

Passados quase trezentos anos desde sua primeira descrição, o MCF permanece ainda hoje pouco compreendido. Com este trabalho, descrevemos a densidade (área porcentual) dos constituintes da matriz 
extracelular no endomísio do MCF por métodos histoquímicos e imunohistoquímicos. Entendemos que o conhecimento adequado da distribuição normal dessas proteínas deve ser reconhecido para facilitar a compreensão dos processos patológicos do MCF e direcionar o tratamento dos distúrbios de deglutição. Como primeiro trabalho publicado sobre o assunto, é uma importante ferramenta para estudos futuros. 
7 CONCLUSÕES 


\section{CONCLUSÕES}

Com este trabalho:

1. Identificamos a presença e mensuramos a área porcentual do colágeno total, das fibras elásticas, do colágeno tipo I, tipo III, da fibronectina e do versican no endomísio do MCF por histoquímica e imunoistoquímica.

2. Não identificamos diferenças estatisticamente significativas em relação ao sexo e à idade nesses constituintes, na amostra estudada pelos métodos aplicados. 
ANEXOS 
ANEXO A

\section{Dados dos cadáveres obtidos no Serviço de Verificação de Óbitos da Capital -São Paulo}

\begin{tabular}{|c|c|c|c|c|c|c|c|}
\hline Identificação & Idade & Sexo & Raça & $\begin{array}{l}\text { Peso } \\
(\mathrm{kg})\end{array}$ & $\begin{array}{c}\text { Altura } \\
\text { (m) }\end{array}$ & Profissão & $\begin{array}{c}\text { Doença de base ou causa } \\
\text { mortis }\end{array}$ \\
\hline CF 01 & 52 & $M$ & $B$ & 50 & 1,70 & $\begin{array}{l}\text { Auxiliar de } \\
\text { expedição }\end{array}$ & Edema agudo de pulmão \\
\hline CF 02 & 65 & $M$ & $B$ & 81 & 1,70 & Eletricista & Infarto agudo do miocárdio \\
\hline CF 03 & 51 & M & B & 91 & 1,80 & Motorista & Infarto agudo do miocárdio \\
\hline CF 04 & 37 & $\mathrm{M}$ & $B$ & 70 & 1,80 & Autônomo & Edema agudo de pulmão \\
\hline CF 05 & 83 & $\mathrm{~F}$ & $P$ & 60 & 1,60 & Sem ocupação & Tromboembolia pulmonar \\
\hline CF 06 & 46 & $M$ & $B$ & 80 & 1,80 & Sem ocupação & Edema agudo de pulmão \\
\hline CF 07 & 68 & M & B & 56 & 1,70 & Vendedor & Infarto agudo do miocárdio \\
\hline CF 08 & 42 & $\mathrm{~F}$ & $\mathrm{~N}$ & 88 & 1,70 & $\begin{array}{l}\text { Empregada } \\
\text { doméstica }\end{array}$ & Infarto agudo do miocárdio \\
\hline CF 09 & 42 & $F$ & $B$ & 64 & 1,70 & $\begin{array}{l}\text { Empregada } \\
\text { doméstica }\end{array}$ & Edema agudo de pulmão \\
\hline CF 10 & 28 & $M$ & $B$ & 67 & 1,90 & Manobrista & Edema agudo de pulmão \\
\hline CF 11 & 71 & $\mathrm{~F}$ & B & 101 & 1,70 & Sem ocupação & Broncopneumonia bilateral \\
\hline CF 12 & 55 & $\mathrm{~F}$ & $\mathrm{P}$ & 65 & 1,60 & Vendedor & Hemorragia meníngea \\
\hline CF 13 & 74 & $M$ & $P$ & 76 & 1,70 & Aposentado & Tromboembolia pulmonar \\
\hline CF 14 & 67 & $M$ & B & 76 & 1,75 & $?$ & Carcinoma hepático \\
\hline CF 15 & 52 & $M$ & $B$ & 61 & 1,60 & $?$ & Encefalopatia hepática \\
\hline CF 16 & 69 & $\mathrm{M}$ & $\mathrm{N}$ & 48 & 1,60 & $?$ & Adenocarcinoma de próstata \\
\hline CF 17 & 60 & $\mathrm{~F}$ & B & $?$ & $?$ & $?$ & Adenocarcinoma de mama \\
\hline CF 18 & 40 & $\mathrm{~F}$ & B & 60 & 1,70 & Do lar & Broncopneumonia bilateral \\
\hline CF 19 & 37 & M & B & 70 & 1,70 & Ajudante geral & Infarto agudo do miocárdio \\
\hline CF 20 & 31 & $M$ & $P$ & 62 & 1,65 & Autônomo & Tuberculose miliar \\
\hline
\end{tabular}




\section{Continuação da tabela}

\begin{tabular}{l|c|c|c|c|c|l|l}
\hline CF 21 & 52 & M & P & 68 & 1,70 & Tintureiro & Infarto agudo do miocárdio \\
\hline CF 22 & 45 & M & N & $?$ & $?$ & $?$ & Broncopneumonia bilateral \\
\hline CF 23 & 80 & M & P & 70 & 1,80 & Tecelão & Infarto agudo do miocárdio \\
\hline CF 24 & 79 & M & B & 67 & 1,80 & Comerciante & Broncopneumonia bilateral \\
\hline CF 25 & 92 & M & B & 75 & 1,70 & Aposentado & Edema agudo de pulmão \\
\hline CF 26 & 28 & M & P & 70 & 1,80 & Vigilante & Tromboembolia pulmonar \\
\hline CF 27 & 29 & M & P & 65 & 1,80 & $\begin{array}{l}\text { Auxiliar de } \\
\text { limpeza }\end{array}$ & Acidente Vascular Cerebral \\
\hline \hline
\end{tabular}

(CF) cricofaríngeo; (?) indica que o dado é desconhecido; (M) masculino; (F) feminino; (B) branca; (P) parda; $(\mathrm{N})$ negra 


\section{ANEXO B}

\section{Método Picrossírius}

Os cortes histológicos foram desparafinados, hidratados e corados durante uma hora em uma solução 0,1\% de Sirius Red (Sirius Red F 3B 200, Mobay Chemical Co, Union, NJ, EUA) dissolvida em ácido pícrico aquoso saturado. Os cortes foram lavados durante cinco minutos em água corrente e contracorados com hematoxilina de Harris fresca durante dois minutos. Foram observados sob microscopia de luz normal para a análise das fibras colágenas. 


\section{ANEXO C \\ Método de Resorcina-fucsina de Weigert com oxidação prévia por oxona}

Os cortes histológicos foram desparafinados e tratados com solução aquosa de Oxona a 10\% (composto monopersulfato, Du Pont, Wilmington, Delaware, EUA) por 40 minutos. Depois de lavados em água corrente por cinco minutos, foram lavados em uma série de etanol com concentrações de 70 a 95\% e colocados na solução corante por uma hora em temperatura ambiente. Após este tempo na solução corante, foram lavados em água corrente por cinco minutos e tiveram a coloração de fundo removida por meio de uma solução de álcool etílico 1\% (1mL de HCl concentrado e 99mL de etanol 70\%). Em seguida, foram lavados em água corrente, desidratados em álcool, diafanizados e montados. 


\section{ANEXO D}

\section{Método Imunoistoquímico}

\section{Hidratação e Bloqueio}

As lâminas foram desparafinadas, hidratadas e em seguida bloqueadas utilizando-se a peroxidase endógena com água oxigenada $\left(\mathrm{H}_{2} \mathrm{O}_{2}\right) 10$ volumes a 3\% por sete ciclos de três minutos de duração, para serem finalmente lavadas com água corrente e Solução Tampão de Fosfato (Phosphate Buffer Solution, PBS).

\section{Recuperação antigênica}

Seguiu-se a recuperação antigênica obtida por meio de tripsina por 20 minutos para os anticorpos específicos para versican e colágeno III e por alta temperatura em citrato $\mathrm{pH}$ 6,0 para os anticorpos colágeno I e fibronectina. Após este período, as lâminas foram novamente lavadas em PBS.

\section{Incubação com os anticorpos primários e secundários}

Os anticorpos primários anti-human Versican (Seikagaku Corporation, Inc., ljamsville, MD, EUA - código:270428) título 1:250, Colagen I (Calbiochem, San Diego, CA, EUA - código:CP19) título1:1000, Colagen III (United States Biological, Swampscott, MA, EUA - código:C7510-12A) título 1:150 e Fibronectin (Dako, Carpinteria, CA, EUA - código:0245) título 1:4000, foram diluídos em Bovine Serum Albumin (BSA), aplicados sobre os cortes e controles (positivo e negativo de tecido) e incubados durante a noite 
(overnight). As lâminas foram então lavadas em PBS e incubadas com anticorpos secundários Envision + Dual link system (DakoCytomation, Carpinteria, EUA, código:K0691) para colágeno III, versican. fibronectina e para o colágeno I Vectastain (Vector Laboratories, Burlingame, CA, EUA), em estufa $37^{\circ} \mathrm{C}$.

\section{$\underline{\text { Revelação }}$}

Após esta etapa, as lâminas foram lavadas em PBS e seguiu-se a revelação com cromógeno 3,3 Diaminobenzidine (Sigma, Steinhein, Alemanha código: D5637). Foram lavadas abundantemente em água corrente e contra-coradas com hematoxilina de Harris (Merck, Darmstadt, Alemanha). Em seguida, foram novamente lavadas em água corrente, desidratadas, diafanizadas e montadas com resina Entellan (Merck, Darmstadt, Alemanha) para microscopia. 
REFERÊNCIAS 


\section{REFERÊNCIAS ${ }^{1}$}

Alberts B, et al. The extracelular matrix of animals. In: Alberts B, Dennis B, Lewis J, Raff M, Roberts K, Watson JD Molecular biology of the cell. $4^{\text {th }}$ ed. Ed New York \& London, Garland, 2002, p. 971-84.

Alnaqeeb MA, Al Zaid NS, Goldspink G. Connective tissue changes and physical properties of developing and ageing skeletal muscle. $J$ Anat. 1984;139:977-89.

Ashoh R, Goyal RK. Manometry and eletromyography of the upper esophageal sphincter in the opossum. Gastroenterology. 1978;74:514-20.

Bode-Lesniewska B, Dours-Zimmermman MT, Odermatt BF, Briner J, Heitz PU, Zimmermann DR. Distribution of large aggregating proteoglycan versican in adult human tissue. J Histochem Cytochem. 1996;44:302-12.

Bonington A, Whitmore I, Mahon M. A histological and histochemical study of the cricopharyngeus guinea-pig. J. Anat. 1987;153:151-61.

Bonington A, Mahon M, Whitmore I. A histological and histochemical study of the cricopharyngeus muscle in man. J. Anat. 1988;156:27-37.

Boyer B, Kern P, Fourtanier A, Labat-Robert J. Age-dependent variations of the byosyntheses of fibronectin and fibrous collagens in mouse skin. Exp Gerontol. 1991;26(4):375-83.

Brownlow $\mathrm{H}$, Whitmore I, Willa PI. A quantitative study of the histochemical and morphometric characteristics of the human cricopharyngeus muscle. $J$ Anat. 1989;166: 67-75.

Buhler RB, Sennes LU, Mauad T, Melo ECM, Silva LFF, Saldiva PH. Collagen fiber and versican distribution with the lamina propria of fetal vocal folds. Laryngoscope. 2008 Feb;118(2):371-4.

${ }^{1}$ De acordo com:

Adaptado de International Committee of medical Journals Editors (Vancouver).

Universidade de São Paulo. Faculdade de Medicina. Serviço de biblioteca e Documentação. Estrutura e apresentação de dissertações e teses. Elaborado por Anneliese Carneiro da Cunha, Maria Julia A.L. Freddi, Maria F. Crestana, Marinalva de S. Aragão, Suely C. Cardoso, Valéria Vilhena. São Paulo, Serviço de biblioteca e Documentação, 1996. 
Carrino DA, Sorrel JM, Caplan Al. Age related changes in proteoglycans of human skin. Arch Biochem Biophys. 2000;373:91-101.

Carvalho HF, Pimentel-Rocco SM. A célula. São Paulo: Editora Manole Ltda; 2001, cap 19, p.217-34: Matrix extracelular.

Carvalho Filho ET, Carvalho CAF, Souza RR. Age related changes in elastic fibers of human heart. Gerontology. 1996;42:211-17.

Costa, MMB. Análise estrutural da faringolaringe e suas implicações na miotomia do cricofaríngeo, na injeção de toxina botulínica e na dilatação por balão. Arq Gastroenterol. 2003;40(2):63-72.

Cotta-Pereira G, Guerra Rodrigo F, Bintencourt-Sampaio S. Oxitalan, elulanin and elastic fibers in human skin. J Invest Dermatol. 1976;66(3): 143-8.

Chow LS, Nair KS. Sarcopenia of male aging. Endocrinol Metabol Clin North Am. 2005;34(4):833-52.

Cook, IJ. Cricopharyngeal function and dysfunction. Dysphagia, 1993, 8: 244-55.

Cruse JP, Edwards DAW, Smith JF, Wyllie, JH. The pathology of cricopharyngeal dysphagia. Histopathol. 1979;3:223-32.

Dantas, DAS. Avaliação do papel da matriz extracelular na musculatura da parede lateral da faringe na fisiopatologia da síndrome da apnéia obstrutiva do sono. [tese]. São Paulo: Faculdade de Medicina, Universidade de São Paulo; 2009

Dejaeger E, Pelemans W, Bibau G, Ponette E. Manoflourographic analysis of swallowing in eldery. Dysphagia. 1994;9:156-61.

Foidart M, Foidart J, Engel, W K. Collagen localization in normal and fibrotic human skeletal muscle. Arch Neurol. 1981;38:152-157.

França, G.V. Medicina legal. 7 ed. Rio de Janeiro, Guanabara Koogan, 2004, p 327-406

Fulp SR, Dalton CB, Castell JA, Castell DO. Aging-related alterations in human esophageal sphincter function. Am J Gastroenterol. 1990;85(12): 1569-72.

Gardner E, et al. Anatomia. 4ª Ed. Guanabara Koogan, 1988, p. 735.

Goyal RK, Martin SB, Shapiro J, Spechler SJ. The role of cricopharyngeus muscle in pharyngoesophageal disorders. Dysphagia. 1993;8:252-58. 
Goyal RJ, Sivarao DV. Functional anatomy and phisiology of sallowing and esophageal motility. In: The esophagus, Filadélfia: Lippincout Williams Wilkins, 1999, p.1-31

Gulati AK, Reddi AH, Zlewski, AA. Distribution of fibronectin in normal and regenerating skeletal muscle. Anat Rec. 1982;204:175-83.

Hanna W, Hederson RD. Nemaline rods in cricopharyngeal dysphagia. Am J Clin Pathol. 1980;74:186-91.

Hardinghan TE, Fosang A J. Proteoglycans: many forms and functions. FASEB. 1992;6:861-70.

Haus JM, Carrithers JA, Trappe SW, Trappe TA. Collagens, cross-linking, and advanced glycation end products in aging human skeletal muscle. $\mathrm{J}$ Appl Physiol. 2007;103:2068-76.

Hila A, Castell JA, Castell, DO. Pharyngeal and upper esophageal sphincter manometry in the evaluation of dysphagia. J Clin Gastroenterol. 2001, 33(5):355-61.

Hynes RO, Yamada KM. Fibronectins: multifunctional modular glycoproteins. J Cell Biol. 1982;95:369-77.

Imamura ST. Estudo do colágeno no músculo estriado de ratos envelhecidos:influência do exercício aeróbio e anaeróbio [tese]. São Paulo:Faculdade de Medicina da Universidade de São Paulo, 1996

Instituto Brasileiro de Geografia e Estatística. População residente por cor ou raça, segundo as grandes regiões e unidades da federação. 2002 Disponível em: <http://www.ibge.gov.br> Acessado em: setembro de 2008

Järvinen TA, Józsa $L$, Kannus $P$ et al. Organization and distribution of intramuscular connective tissue in normal and immobilized muscles. J Musc Res Cell Motil. 2002; 23:245-254

Kahrilas PJ. Anatomy, physiology and pathophisyology of dysphagia. Acta Oto-rhino-laryngol Belg. 1994;48:97-117.

Kannus $P$, Jozla L, Järvinen TA, Järvinen TLN, Kvist $M$, Natri A Järvien $M$. location and distribution of non-collagenous matrix proteins in musculoskeletal tissues of rat. Histochemical Journal. 1998;30:799-810.

Kelly JH, Kuncl RW. Myology ok the pharyngoesophageal segment: gross anatomic and histologic characteristics.Laryngoscope. 1996,106:713-720.

Kern MS, Bardan E, Arndorfer R, Hofmann C, Ren J, Shaker R. Comparison of upper esophageal sphincter opening in healthy asymptomatic young and elderly volunteers. Ann Otol Rhinol Laryngol. 1999;108:982-89. 
Kielty CM, Sherratt MJ, Shuttleworth CA. Elastic fibers. J Cell Sci. 2000; 115:2817-28.

Kirchner JA. The motor activity of the cricopharyngeus muscle. Laryngoscope. 1958;68(7):1119-59.

Kovanen V. Effects of ageing and physical training on rat skeletal muscle. Acta Physiol Scand. 1989;135 (Suppl A577).

Kovanen V. Intramusclar extracellular matrix: complex enviromment of muscle cells. Exer Sport Sci Rev. 2002;30(1):20-5.

Kovanen V, Suominen $\mathrm{H}$, Peltonen L. Effects of aging and life-long physical training on collagen in slow and fast skeletal muscle in rats. Cell Tissue Res.1987;248:247-55.

Kristmundsdottir F, Mohon M, Froes MMQ, Cumming, WJK. Histomorphometric and histopathological study of the human cricopharyngeus muscle in health and in motor neuron disease. Neuropathol App Neurobiol. 1990;16:461-75.

Kurosu, H. Biochemical studies on collagen and connectin from human skeletal muscle: age-related changes in the properties of elasticity. Nippon Seikeigeka Gakkai Zasshi.1979;53(11):1641-52.[Abstract, PUBMED 2008]

Labat-Robert J, Bihari-Varga M, Robert, L. Extracellular matrix. FEBS. 1990;268(2):386-93.

Lang IM. Anatomy and physiology of the upper esophageal sphincter. Am J Med. 1997;103:50-5.

Laurikainen E, Aitasalo K, Halonen P, Falck B, Kalimo H. Muscle pathology in idiopathic cricopharyngeus dysphagia. Enzime histochemical and electron microscopic findings. Eur Arch Otorhinolaryngol. 1992;249:216-23.

Lerche, W. The esophagus and pharynx in action, p141-142, Charles C Thomas 1950.

Lexell J, Taylor CC, Sjöström M. What the cause of the ageing atrophy? Total number, size and proportion of different fiber-types studied in whole vastus lateralis muscle from 15-83-year-old men. $J$ Neuro Sci. 1988;84(2):275-94.

Lobat-Robert J, Bihari-Varga M, Robert L. Extracellular matrix. FEBS, 268(2), 386-93.

MacCarthy KJ, Accavitti M, Couchman JR. Immunological characterization of a basement membrane-specific chondroitin sulphate proteoglycan. J Cell Biol.1989;109 (6):3187-98. 
McComas AJ, Lipton ARM, Sica REP. Motoneuron disease and aging. Lancet. 1973;2:1477-80.

MacLenna WR, Hall MRP, Timothy JI, Robinson M. Is weakness in old age due to muscle wasting? Age Ageing. 1980;9:188-92

Mauad T, Leick-Maldonado EA, Lemos M, Dolhnikoff M, Caldini EG, Montes GS, Saldiva PHN. The role of the collagenous and elastic fibers in modulating bronchoconstricton. Braz J Med Biol Res. 1996;93(9):1195-9.

McKee GJ, Johnston BT, McBride GB, Primrose WJ. Does age or sex affect pharyngeal swallowing? Clin Otolaryngol Allied Sci. 1998;23:100-6.

Melo ECM. Distribuição das fibras colágenas na lâmina própria e no músculo da prega vocal humana: estudo descritivo e histomorfométrico. [tese]. São Paulo: Faculdade de Medicina, Universidade de São Paulo; 2004.

Merrillees JM, Ching P, Beamont B, Hinek A, Wight T, Black P. Changes in elastin, elastin binding protein and versican in alveoli chronic obstructive pulmonary disease. Resp Research. 2008;9(41):1-9.

Michelacci YM. Collagens and proteoglycans of the corneal extracellular matrix. Braz J Med Biol Res. 2003;36(8):1037-46.

Mohan S, Radha E. Age related changes in rat muscle collagen. Gerontology. 1980;26(2):61-7.

Mohan S, Radha E. Collagens in aging muscles. Experientia. 1975, 31:118183

Montes GS. Structural biology of the fibers of the collagenous and elastic systems. Cell Biol Int. 1996;20(1):15-27.

Montes GS, Junqueira LC. The use of picrosirius-polarization method for study of the biopathology of collagen. Mem Inst Oswaldo Cruz. 1991;86:111.

Mu L, Sanders I. Neuromuscular compartments and fiber-type regionalization in the humana inferior pharyngeal constrictor muscle. Anat Rec. 2001 264:367-77.

Nita, LM. Estudo histoquímico e ultra-estrutural da distribuição das fibras da matriz extracelular na prega vocal humana fetal no período neonatal. [tese]. São Paulo: Faculdade de Medicina, Universidade de São Paulo; 2008.

Parry DAD, Craig AS. Collagen fibrils during development and maturation and their contribution to the mechanical attributes of connective tissue. In: Nimni ME (ed.) Collagen. Vol II. Boca-Raton, CRC Press, 1988. p.1-23. 
Pecora JR, Rodrigues CJ, Rodrigues Júnior, AJ, Salomão O. Densidade linear do sistema de fibras elásticas dos ligamentos patelar, cruzado anterior e cruzado posterior. Acta Ortop Bras. 2001;9(1):55-62.

Pickering J, Boughner DR. Quantitative assessment of the age of fibrotic lesions using polarized light microscopy and digital image analysis. $A m \mathrm{~J}$ Pathol, 1991 138:1225-31

Pukkila MJ, Kasunen AST, Virtaniemi JA, Kumpulainen EJ, Johansson RT, Kellokoski Jk, Nuutinen J, Kosma VM. Versican expression in pharyngeal sqaumous cell carcinoma: an immunohistochemical study. J Clin Pathol, 2004;57:735-39.

Robbins J, Hamilton JW, Lof GL, Kempster GB. Oropharyngeal swallowing in normal adults of differents ages. Gastroenterology. 1992;103:823-29.

Robert L, Labat-Robert J. Aging of connective tissues: from genetic to epigenetic mechamisms. Biogerontology. 2000;1:123-31.

Rodrigues CJ. Influência do envelhecimento sobre o músculo diafragma estudo das fibras musculares, do sistema elástico e do colágeno em ratos Wistar. [tese]. São Paulo: Faculdade de Medicina, Universidade de São Paulo; 1994.

Rodrigues CJ, Rodrigues Junior AJ, Bohm GM. Effects of aging on muscle fibers and collagen content of the diaphragm: a comparison with the rectus abdominis muscle. Gerontology. 1996;42:218-28.

Rodrigues CJ, Rodrigues Júnior, AJ. A comparative study of aging of the elastic fibers system of the diaphragm and the rectus abmominis muscles in rats. Braz J Med Biol Res. 2000;33(12):1449-54.

Rosenbloom J, William RA, Mechan R. Extracellular matrix 4: the elastic fiber. FASEB . 1993;7:1208-18.

Rosenfield DB, Miller RH, Sessions RB, Patten BM. Morphological and histochemical characteristics of laryngeal muscle. Acta Otolaryngol. 1982; 108:662-666.

Ross R. The elastic fiber. J Histochem Cytochem. 1973;21(3):199-208.

Rosner B. Fundamentals of Biostatistics. Boston, PWS Publishers, Second edition, 1986, 584pp.

Ruoslahti E. Structure and biology of proteoglycans. Annu Rev Cell Biol. 1988;4:229-55.

Salonen V, Lehto M, Kalimo H, Penttinen R, Aro H. Changes in intramuscular collagen and fibronectin in denervation atrophy. Muscle Nerve. 1985;8:125131. 
Sanders I, Mu L. Anatomy of the human internal superior laryngeal nerve. Anat Rec. 1998;252:646-56.

Shapiro SD, Endicott SK, Province MA, Pierce JA, Campbell EJ. Marked longevity of human lung parenchymal elastic fibers deduced from prevalence of D-aspartate and nuclear weapons-related radiocarbon. $\mathrm{J}$. Clin. Invest. 1991;87:1828-34.

Shaw DW, Cook IJ, Gabb M, Holloway RH, Simula ME, Panagopoulos V, Dent J. Influence of normal aging on oral-pharyngeal and upper esophageal sphincter function during swallowing. Am J Physiol. 1995;268:389-96.

Singh S, Hamdy S. The upper esophageal sphincter. Neurogastroenterol Motil. 2005;17:3-12.

Sivarao DV, Goyal RK. Functional anatomy and phisiology of the upper esophageal sphincter. Am J Med. 2000;108:27-37.

Sorrel JM, Carrino DA, Baber MA, Caplan, Al. Versican in human fetal skin development. Anat Embryol. 1999;119:45-56.

Souza RR. Aging of myocardial collagen. Biogerontology. 2002;3:325-35.

Staff D, Shaker R. Aging in the gastrointestinal tract. DM. 2001, 47: 72-101.

Takala TE, Virtanen P. Biochemical composition of muscle extracellular matrix: the effect of loading. Scand J Med Sci Sports. 2000;10:321-25.

Wigth TN. Versican: a versatile extracellular matrix proteoglycan in cell biology. Curr Opin Cell Biol. 2002;14:617-23.

Yoon JH, Halper J. Tendon proteoglycans: biochemistry and function. J Musculoskelet Neuronal Interact. 2005;5:22-34. 


\section{APENDICE}

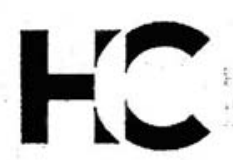

\section{APROVAÇÃO}

A Comissão de Ética para Análise de Projetos de Pesquisa - CAPPesq da Diretoria Clínica do Hospital das Clínicas e da Faculdade de Medicina da Universidade de São Paulo, em sessão de 28.07.05, APROVOU o Protocolo de Pesquisa $n^{\circ}$ 604/05, intitulado: "Alterações histológicas do tecido conectivo do músculo cricofaríngeo correlacionadas com envelhecimento" apresentado pelo Departamento de OFTALMOLOGIA E OTORRINOLARINGOLOGIA.

Cabe ao pesquisador elaborar e apresentar à CAPPesq, os relatórios parciais e final sobre a pesquisa (Resolução do Conselho Nacional de Saúde $n^{\circ} 196$, de 10.10.1996, inciso IX. 2, letra "c")

Pesquisador(a) Responsável: Prof. Dr. Luiz Ubirajara Sennes

Pesquisador (a) Executante: Dra. Raquel Aguiar Tavares

CAPPesq, 28 de Julho de 2005.

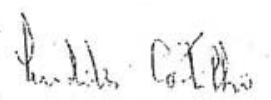

PROF. DR. EUCLIDES AYRES DE CASTILHO

Presidente da Comissão de Ética para Análise de Projetos de Pesquisa

\footnotetext{
Comissão de Ética para Análise de Projetos de Pesquisa do HCFMUSP e da FMUSP

Clínica do Hospital das Clínicas da Faculdade de Medicina da Universidade de São Paulo

Rua Ovidio Pires de Campos. 225, $5^{\circ}$ andar - CEP 05430010 - Sảo Paulo - SP

Fone: 011 - 30696442 fax : $011 \cdot 30696492$ - e-mail : cappesg@hcnet.usp.br / secretariacappesq2@hcnet, usp.br 